\title{
Arbeidsmarktverkenning zorg- en welzijnssector
}

Citation for published version (APA):

van de Loo, P. (1995). Arbeidsmarktverkenning zorg- en welzijnssector. Researchcentrum voor Onderwijs en Arbeidsmarkt, Faculteit der Economische Wetenschappen. ROA Reports No. 4 https://doi.org/10.26481/umarep.1995004

Document status and date:

Published: 01/01/1995

DOI:

10.26481/umarep.1995004

Document Version:

Publisher's PDF, also known as Version of record

\section{Please check the document version of this publication:}

- A submitted manuscript is the version of the article upon submission and before peer-review. There can be important differences between the submitted version and the official published version of record.

People interested in the research are advised to contact the author for the final version of the publication, or visit the DOI to the publisher's website.

- The final author version and the galley proof are versions of the publication after peer review.

- The final published version features the final layout of the paper including the volume, issue and page numbers.

Link to publication

\footnotetext{
General rights rights.

- You may freely distribute the URL identifying the publication in the public portal. please follow below link for the End User Agreement:

www.umlib.nl/taverne-license

Take down policy

If you believe that this document breaches copyright please contact us at:

repository@maastrichtuniversity.nl

providing details and we will investigate your claim.
}

Copyright and moral rights for the publications made accessible in the public portal are retained by the authors and/or other copyright owners and it is a condition of accessing publications that users recognise and abide by the legal requirements associated with these

- Users may download and print one copy of any publication from the public portal for the purpose of private study or research.

- You may not further distribute the material or use it for any profit-making activity or commercial gain

If the publication is distributed under the terms of Article $25 \mathrm{fa}$ of the Dutch Copyright Act, indicated by the "Taverne" license above, 


\section{Arbeidsmarktverkenning zorg- en welzijnssector}

ROA-R-1995/4

P.J.E. van de Loo

Researchcentrum voor Onderwijs en Arbeidsmarkt

Faculteit der Economische Wetenschappen en Bedrijfskunde Rijksuniversiteit Limburg

Maastricht, december 1995 
ISBN 90-5321-180-2 


\section{Inhoudsopgave}

Bladzijde

Voorwoord

1 Inleiding 1

1.1 Achtergrond 1

1.2 Opzet arbeidsmarktverkenning 2

2 Arbeidsmarktinformatie: behoefte en beschikbaarheid 5

2.1 Informatiebehoefte 5

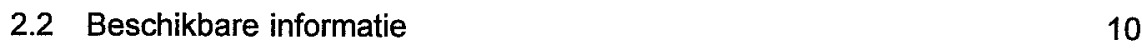

$\begin{array}{ll}2.3 & \text { Mismatch benodigde en beschikbare informatie } \\ \end{array}$

3 Actuele arbeidsmarktsituatie zorg- en welzijnssector 23

3.1 Omvang en samenstelling beroepsbevolking 23

3.1.1 Omvang naar beroeps- en bedrijfsklasse 23

$\begin{array}{ll}\text { 3.1.2 Man-/vrouwverhouding } & 26\end{array}$

$\begin{array}{ll}\text { 3.1.3 Full-time en part-time arbeid } & 28\end{array}$

$\begin{array}{ll}3.1 .4 \text { Leeftijdsopbouw } & 29\end{array}$

$\begin{array}{ll}3.1 .5 \text { Opleidingsachtergrond } & 30\end{array}$

3.2 Knelpunten op de arbeidsmarkt 32

$\begin{array}{ll}\text { 3.2.1 Het potentiële aanbod } & 32\end{array}$

$\begin{array}{ll}3.2 .2 \text { Vacatures } & 34\end{array}$

$\begin{array}{ll}\text { 3.2.3 Werkloosheid } & 35\end{array}$

3.2.4 Risico-indicatoren: conjunctuurgevoeligheid \&
uitwijkmogelijkheden

3.2.5 Concurrentie in arbeidsmarktsegmenten zorg-en welzijnsector $\quad 40$

3.2.6 Werving, selectie en functie-eisen $\quad 45$

3.2.7 Arbeidsvoorwaarden: werkweek, baanzekerheid, inkomen $\quad 48$

$\begin{array}{ll}3.2 .8 \text { Ziekteverzuim } & 52\end{array}$

$\begin{array}{ll}\text { 3.2.9 Personeelsverloop } & 53\end{array}$

4 Toekomstig arbeidsmarktperspectief zorg- en welzijnssector 59

$\begin{array}{ll}4.1 & \text { Inleiding } \\ 4.2 & 59\end{array}$

4.2 Werkgelegenheidsontwikkeling 64

$\begin{array}{ll}4.3 \text { Vervangingsvraag } & 66\end{array}$

$\begin{array}{lll}4.4 & \text { Baanopeningen } & 68\end{array}$

$\begin{array}{lll}4.5 & \text { Instroom van schoolverlaters } & 70\end{array}$

$\begin{array}{lll}4.6 & \text { Toekomstig arbeidsmarktperspectief } & 71\end{array}$ 
5 Conclusies en aanbevelingen $\quad 73$

5.1 Conclusies arbeidsmarkt zorg- en welzijnssector 73

5.2 Mogelijkheden voor arbeidsmarktinformatiesysteem zorg- en welzijn 76

Bijlage 1 Relevante gegevensbronnen en literatuur 87

Bijlage 2 Overzicht kerncijfers per beroepsklasse en opleidingsrichting $\quad 89$

Bijlage 3 Samenstelling beroepsbevolking naar beroepsklassen, bedrijfsklassen en opleidingstypen

Bijlage 4 Indeling ROA-bedrijfsklassen, ROA-beroepsklassen en ROA-opleidingstypen

Bijlage 5 Overzicht van BVG-beroepsgroepen per beroependomein zorg- en welzijnssector

Bijlage 6 Overzicht van CBS-beroepen per beroependomein zorg- en welzijnssector 


\section{Voorwoord}

De stuurgroep van het Platform Kwalificatiebeleid Zorg en Welzijn heeft het Researchcentrum voor Onderwijs en Arbeidsmarkt (ROA) verzocht verslag te doen van de recente arbeidsmarktontwikkelingen voor de sociaal-agogische beroepsbeoefenaren in de sector zorg en welzijn. De arbeidsmarktverkenning levert beleidsrelevante kengetallen op met betrekking tot de actuele èn toekomstige ontwikkelingen in die sector. Hierbij komen arbeidsmarktindicatoren over zowel de vraagzijde (i.c. werkgevers) als aanbodzijde (i.c. - potentiële - werknemers) aan bod. Verder is het voor het platform van belang dat de gepresenteerde informatie zoveel mogelijk is gebaseerd op periodiek verzamelde en recente gegevens, die zowel in de tijd als met andere veelvuldig gebruikte databronnen goed vergelijkbaar zijn. De arbeidsmarktverkenning is in de eerste plaats bedoeld voor beleidsmakers die betrokken zijn bij het kwalificatiebeleid in de zorg- en welzijnssector.

De in dit rapport weergegeven informatie is grotendeels ontleend aan actuele gegevens en middellange termijn prognoses (tot 2000) uit het informatiesysteem onderwijs-arbeidsmarkt, een systeem dat het ROA de afgelopen jaren heeft ontwikkeld en uitgebouwd. Dit informatiesysteem genereert actuele arbeidsmarktgegevens, trends en toekomstige arbeidsmarktperspectieven voor inmiddels ruim 90 beroepsklassen en bijna 80 opleidingstypen die tezamen de gehele Nederlandse arbeidsmarkt beslaan. Het informatiesysteem bevat aan de ene kant door het ROA bewerkte gegevens uit de Enquête Beroepsbevolking van het Centraal Bureau voor de Statistiek (CBS) en de meerjarenramingen van het Centraal Planbureau (CPB) en de referentieramingen van het Ministerie van Onderwijs, Cultuur en Wetenschappen. Aan de andere kant zijn in het informatiesysteem ook de resultaten opgenomen van grootschalige schoolverlatersonderzoeken, die het ROA al enkele jaren zelf uitvoert.

De arbeidsmarktverkenning betreft de beroepsklasse van maatschappelijk en cultureel werkers. Het platform is hierbij in het bijzonder geïnteresseerd in arbeidsmarktinformatie over de beroepsgroep van sociaal-pedagogisch werkers. Zij heeft het ROA dan ook verzocht om daarover beschikbare informatie in dit rapport weer te geven, en voor zover dat niet mogelijk is, aan te geven welke stappen nodig zijn om in de toekomst wel in deze informatiebehoefte te kunnen voorzien. Het motto hierbij is: "van grof naar fijn, op termijn".

Het onderzoek is uitgevoerd in opdracht van de stuurgroep van het Platform Kwalificatiebeleid Zorg en Welzijn te Rijswijk door drs. P.J.E. van de Loo, onder leiding van dr. R.K.W. van der Velden. Bij de verwerking van de gegevens hebben 
drs. R.J.P. Dekker, A. Dikmans, drs. A.G.M. Matheewsen, H.W. Stegeman en B. Weerkamp assistentie verleend.

Verder wordt een woord van dank gericht aan de leden van de voor dit onderzoek samengestelde begeleidingscommissie, te weten:

De heer dr. P.A.M. van den Bogaardt, Platform Kwalificatiebeleid Zorg en Welzijn te Rijswijk;

Mevrouw drs. F.M. Alsem, de heer drs. H. Bijker, mevrouw drs. L. Heikoop, Vereniging van Ondernemeningen in de Gepremieerde en Gesubsidieerde Sector (VOG) te Rijswijk;

De heer drs. H.A.M. Hens, de heer drs. J.M.A. de Smet, Nederlands Instituut voor Zorg en Welzijn (NIZW) te Utrecht;

De heer J.P.N. Timmerman, Federatie van Werkgeversverenigingen (FW) te Rijswijk.

Maastricht, december 1995 


\section{Inleiding}

\subsection{Achtergrond}

Adequate dienstverlening in de sector zorg en welzijn is pas mogelijk als toereikende aantallen en goed gekwalificeerde beroepsbeoefenaren ingezet kunnen worden. De zorg en hulpverlening is immers mensenwerk. De missie van de bedrijfstak zorg en welzijn luidt daarbij als volgt: de bedrijfstak zorg en welzijn verleent op professionele wijze diensten die er op gericht zijn het persoonlijk en maatschappelijk functioneren van mensen te bevorderen en belemmeringen die daarbij optreden op te heffen (NIZW, Proeve van een beroepenstructuur voor zorg en welzijn, 1992). Het kwalificatiebeleid heeft tot doel om via de gezamenlijke inspanning van de actoren in de sector, de sociale partners, regionale en landelijke overheden en de beroepsopleidingen, de aansluiting tussen het onderwijs en de beroepspraktijk te verbeteren. De kwalificaties van de beroepsbeoefenaren in de zorg- en welzijnssector moeten op het vereiste niveau gebracht en gehouden worden. De dynamiek van de arbeidsmarkt is daarbij een gegeven. Maatschappelijke en arbeidsmarktontwikkelingen dienen helder in beeld gebracht te zijn, alvorens de actoren over de aanpak naar aanleiding van de gevolgen van deze ontwikkelingen voor de beroepspraktijk nieuw beleid en afspraken kunnen maken. Uiteindelijk gaat het erom de (ver)nieuwde kwalificatie-eisen van het werkveld te vertalen in de eindtermen en leerplannen van de beroepsopleidingen. Voortdurende innovatie staat daarbij centraal (Platform Kwalificatiebeleid Zorg en Welzijn, Informatiebulletin 3, oktober 1994).

De stuurgroep van het Platform Kwalificatiebeleid Zorg en Welzijn heeft in haar werkprogramma een aantal thema's centraal gesteld. Een daarvan betreft het opstellen van een bedrijfstakverkenning, welke opgevat kan worden als een reeks van thematische verkenningen die ofwel de gehele sector, ofwel een deel van deze sector betreffen. Deze bedrijfstakverkenning zou in ieder geval de arbeidsmarktsituatie moeten omvatten. Hierbij is beter zicht gewenst op de actuele en toekomstige vooruitzichten voor de beroepsbeoefenaren in de zorg- en welzijnssector, evenals op de perspectieven voor de afgestudeerden van de diverse sociaal-agogische beroepsopleidingen. Het platform heeft daarbinnen behoefte aan meer toegespitste informatie over een specifiek beroependomein, i.c. de beroepsgroep van sociaal-pedagogisch werkers. De stuurgroep van het platform heeft het ROA gevraagd het onderdeel met betrekking tot de arbeidsmarktverkenning voor de sector zorg en welzijn invulling te geven, voornamelijk op basis van de informatie die is opgenomen in het informatiesysteem onderwijs-arbeidsmarkt van het ROA. 


\subsection{Opzet arbeidsmarktverkenning}

Het doel van dit pilot-onderzoek is meerledig. In de eerste plaats is het ROA verzocht om de bij haar beschikbare informatie over de sociaal-agogen in de zorgen welzijnssector op overzichtelijke en samenhangende wijze te presenteren. In de tweede plaats is het ROA nagegaan welke mogelijkheden er zijn om de arbeidsmarktinformatie in de toekomst nog beter aan te laten sluiten op de informatiebehoefte van het platform. Al bij de start van dit pilot-onderzoek was namelijk bekend dat op dit moment geen landelijk en periodiek verzamelde arbeidsmarktgegevens voorhanden zijn die geheel in de informatiebehoeften van het platform kunnen voorzien. De discrepantie tussen de door het platform gewenste en beschikbare informatie betreft met name het aggregatieniveau van de arbeidsmarktgegevens (zie ook hoofdstuk 2). Er is weliswaar veel informatie over de arbeidsmarktsituatie in de zorg en welzijnssector voor handen, maar bij elkaar vormt dit wel een soort 'lappendeken' die bovendien te 'grof' is wat betreft de gehanteerde indelingen.

Om een goed inzicht te krijgen in de bruikbaarheid van de beschikbare gegevens is besloten deze informatie eerst eens goed op een rijtje te zetten, alvorens aan te geven op welke punten de informatievoorziening verbeterd dient te worden om - op termijn - beter in de informatiebehoefte te kunnen voorzien.

Het informatiesysteem onderwijs-arbeidsmarkt bevat veel arbeidsmarktinformatie, onderverdeeld naar een veelheid van sectoren, beroepsklassen en opleidingstypen, die tezamen de gehele Nederlandse beroepsbevolking betreffen. Daarnaast beschikt het ROA over informatie met betrekking tot de arbeidsmarktpositie van schoolverlaters. Bij zowel het informatiesysteem als het schoolverlatersonderzoek vormen de resultaten over de sector zorg- en welzijn een klein onderdeel uit een groter geheel dat in de eerste plaats is gericht op het beschrijven van algemene arbeidsmarktprocessen.

Het doel van deze arbeidsmarktverkenning is nu net om de focus op de sociaalagogische beroepsbeoefenaren in de sector zorg en welzijn zèlf te richten, waarbij iedere keer een arbeidsmarktindicator voor de sociaal-agogische beroepen en opleidingen wordt behandeld. De informatie uit het informatiesysteem en de schoolverlatersonderzoeken wordt daarbij aangevuld met gegevens uit het panelonderzoek dat het ROA onder de Noord-Nederlandse werkgevers uit specifiek de zorg- en welzijnssector heeft uitgevoerd. Op deze wijze kan een overzichtelijke en samenhangende beschrijving van de arbeidsmarktpositie van de beroepsbeoefenaren in de zorg- en welzijnssector worden samengesteld. 
Wanneer alleen de informatie die wat betreft aggregatieniveau, definities, en afbakening geheel zou aansluiten op de wensen daarover bij het platform, zou er bijzonder weinig over de arbeidsmarktontwikkelingen in de zorg- en welzijnssector gerapporteerd kunnen worden. Deze dusdanig gedesaggregeerde en geclassificeerde informatie is namelijk niet of nauwelijks voorhanden of (voor onderzoek) beschikbaar en bruikbaar.

Om toch een goed, doch globaal, inzicht te krijgen in de arbeidsmarktprocessen in de sector zijn in deze verkenning een aantal indicatoren opgenomen die een helder beeld geven van de actuele en toekomstige arbeidsmarktsituatie van beroepsbeoefenaren in de zorg-en welzijnssector. Er is in deze verkenning bewust een groot aantal arbeidsmarktindicatoren opgenomen, steeds voorzien van een inhoudelijke en methodisch-technische toelichting. Wanneer op termijn de arbeidsmarktgegevens wat betreft definities, classifaties en afbakening beter aansluiten bij de wensen hierover van het platform, kan zo een goed onderbouwde keuze worden gemaakt voor het opnemen van kerncijfers in een (toekomstige) bedrijfstak- of arbeidsmarktverkenning over de arbeidsmarktsituatie voor de beroepsbeoefenaren in de sector zorg en welzijn.

De informatieve waarde van de arbeidsmarktgegevens die nu in de hoofdstukken 3 en 4 zijn opgenomen is weliswaar niet optimaal, maar zeker bruikbaar voor het formuleren van kwalificatie-, en daarmee samenhangend onderwijs-, scholings- en arbeidsmarktbeleid voor de zorg- en welzijnssector. In feite is gekozen voor een systematiek en proces dat men kort en bondig zou kunnen aanduiden met het motto: "van grof naar fijn, op termijn".

Met het oog op het verbeteren van de informatieve waarde van de arbeidsmarktinformatie voor de sector, wordt daarom in hoofdstuk 2 ruim aandacht besteed aan de eventuele discrepanties tussen de benodigde en beschikbare informatie op dit moment. Nadat in de daarop volgende hoofdstukken de actuele en toekomstige arbeidsmarktsituatie voor de zorg- en welzijnssector is besproken, worden in hoofdstuk 5 aanbevelingen gedaan voor een verbeterde informatievoorziening voor het in beeld brengen van de sectorale arbeidsmarktontwikkelingen.

In hoofdstuk 5 worden uiteraard ook een aantal inhoudelijke conclusies ten aanzien van de ontwikkelingen op de arbeidsmarkt van deze sector zelf aangegeven, op basis van het in hoofdstuk 3 en 4 geschetste beeld.

In hoofdstuk 3 komt de actuele arbeidsmarktsituatie in de zorg en welzijnssector aan bod, evenals de recente ontwikkelingen daarin. In paragraaf 3.1 wordt eerst een overzicht gegeven van de omvang en samenstelling van de beroepsbevolking die in de zorg- en welzijnssector werkzaam is. In deze paragraaf wordt bijvoorbeeld 
de man-/vrouwverhouding in de beroepsklasse van maatschappelijk en cultureel werkers aangegeven, evenals de opleidingsachtergrond van de beroepsbeoefenaren en het aandeel van part-timers in deze beroepsklasse. Bovendien komt de samenhang tussen een groot aantal deelsectoren in de zorg- en welzijnssector en de onderscheiden beroepsklassen aan bod. De situatie in de zorgen welzijnssector wordt daarbij steeds vergeleken met het landelijke beeld. Paragraaf 3.2 behandelt de mogelijke knelpunten in de zorg-en welzijnssector op het arbeidsmarktterrein. Het gaat hierbij niet alleen om kwantitatieve vraagstukken, zoals de instroom van schoolverlaters in het werkveld (het potentiële aanbod), de vacatures, werkloosheid en conjunctuurgevoeligheid, maar tevens om indicatoren die eventuele kwalitatieve knelpunten aan het licht brengen. Hierbij gaat het ondermeer om de uitwijkmogelijkheden van beroepsbeoefenaren op de arbeidsmarkt, de werving-, selectie- en functie-eisen door werkgevers, alsmede de arbeidsvoorwaarden voor werk in de zorg- en welzijnssector, het ziekteverzuim en mogelijk - personeelsverloop in de instellingen.

In hoofdstuk 4 staat het toekomstig arbeidsmarktperspectief in de zorg- en welzijnssector centraal. Het gaat hier om de periode 1995-2000. Na een inleiding in de eerste paragraaf, wordt in de tweede paragraaf van dit hoofdstuk nagegaan hoe de werkgelegenheidssituatie zich (kwantitatief) zal ontwikkelen: het gaat hier om de vraag in hoeverre de werkgelegenheid zich de komende jaren zal uitbreiden. Vervolgens komt in paragraaf 4.3 de vervangingsvraag aan de orde. De kansen voor nieuwkomers (en herintreders) op de arbeidsmarkt zijn namelijk niet alleen afhankelijk van nieuw geschapen banen, maar vooral ook van het kunnen vervangen van mensen die uit het werkveld vertrekken en/of de arbeidsmarkt (tijdelijk of deels) gaan verlaten in verband met pensionering, gezinstaken, arbeidsongeschiktheid e.d. In paragraaf 4.4 wordt een overzicht gegeven van de optelsom van deze uitbreidings- en vervangingsvraag: de baanopeningen. Dit voor zover de toekomstverwachtingen ten aanzien van de vraagzijde in de sector zorgen welzijn. Vervolgens wordt in paragraaf 4.5 een inschatting gegeven van de ontwikkelingen aan de aanbodzijde van de arbeidsmarkt in deze sector. Het betreft hier de instroom van schoolverlaters uit de sociaal-agogische beroepsopleidingen. Vervolgens worden in paragraaf 4.6 de ontwikkelingen aan de vraagzijde van de arbeidsmarkt geconfronteerd met de ontwikkelingen aan de aanbodzijde van de arbeidsmarkt, waaruit dan het toekomstperspectief voor schoolverlaters uit de betreffende beroepsopleidingen kan worden afgeleid. 


\section{Arbeidsmarktinformatie: behoefte en beschikbaarheid}

\subsection{Informatiebehoefte}

\section{Gebruikersgroepen en gebruiksmogelijkheden}

De gegevens zouden in de eerste plaats informatie moeten opleveren voor beleidsmakers in dienst van de sociale partners, (landelijke) overheid, het georganiseerde onderwijsveld, de arbeidsvoorziening e.a. intermediairs op het terrein van onderwijs en arbeid, voor zover het de zorg- en welzijnssector betreft. Bij deze arbeidsmarktverkenning is uitdrukkelijk de nadruk gelegd op het landelijk beleidskader. Deze gebruikers in het zorg- en welzijnsveld kunnen de arbeidsmarktgegevens benutten bij het kwalificatiebeleid, en het daarmee samenhangende onderwijs-, scholings- en arbeidsmarktbeleid.

In een tijd dat het kwalificatiebeleid en de daaraan gekoppelde kwaliteitszorg in alle werk- en onderwijsinstellingen meer en meer gemeengoed gaat worden, ligt het voor de hand om - op termijn - ook voor deze individuele instellingen in de zorg- en welzijnssector arbeidsmarktinformatie te genereren (zie verder hoofdstuk 5). Deze informatie zou enerzijds goed moeten aansluiten op de (personeels)informatiesystemen van de instellingen zelf, en anderzijds kengetallen moeten opleveren die op regionaal en landelijk niveau met de gegevens van de eigen instelling vergeleken kunnen worden. Een soort 'human accounting' dus (zie ook Van de Loo en Van der Velden, 1993). Goede branche-afspraken en een centrale regie omtrent inrichting, gebruik en beheer van de door de werkgevers gebruikte (personeels)informatiesystemen, welke vaak een onderdeel vormen van de salarisen ziekteverzuimsystemen, zijn hierbij een eerste vereiste. Om te komen tot een voor arbeidsmarktonderzoek bruikbare set van kengetallen is hierbij tevens onderzoeksexpertise noodzakelijk.

\section{Inhoud informatie}

De informatie zou kengetallen moeten opleveren met betrekking tot de actuele en toekomstige stromen op de arbeidsmarkt in de zorg- en welzijnssector. Dit om ook toekomstige knelpunten in de sector in kaart te kunnen brengen. De informatie zou zowel de vraag- als aanbodzijde moeten belichten, en naast indicatoren over de kwantitatieve arbeidsmarktdiscrepanties ook kengetallen omtrent de kwalitatieve aansluiting op de arbeidsmarkt moeten bevatten. De informatie uit de zorg- en welzijnssector zou daarbij steeds vergeleken moeten worden met het landelijke beeld met betrekking tot het betreffende onderdeel van de arbeidsmarktsituatie. 
De meest volledige (en overzichtelijke) beschrijving van de actuele en toekomstige arbeidsmarktsituatie wordt verkregen aan de hand van een zogenaamd 'stroommodel'. Bovendien vormt een stroommodel een goede basis voor een periodieke - eventueel geautomatiseerde - arbeidsmarktverkenning, welke uiteraard iedere keer aangevuld kan worden met een specifiek beleidsrelevant thema dat op een bepaald moment actueel is. In een stroommodel worden niet alleen de aantallen werkzame en werkloze personen op een bepaald moment in kaart gebracht (via zogenaamde 'standcijfers'), maar wordt ook de dynamiek van de arbeidsmarkt weergegeven voor de onderscheiden periode. Binnen de zorg- en welzijnssector bestaan de stromen in een dergelijk model uit:

* De instroom op de arbeidsmarkt in de zorg- en welzijnssector, uitgesplitst in:

- schoolverlaters;

- werklozen;

- herintreders van buiten de arbeidsmarkt;

- baan-baan mobiliteit vanuit functies buiten de zorg- en welzijnssector.

* De doorstroom binnen de zorg- en welzijnssector, doordat personen binnen deze sector een ander beroep gaan uitoefenen of minder uren gaan werken (ook doorstroom naar andere werkgevers binnen deze sector valt hieronder).

* De uitstroom uit de arbeidsmarkt, onderverdeeld naar:

- uitstroom als gevolg van overlijden, VUT/pensioen, arbeidsongeschiktheid e.d.;

- uitstroom als gevolg van - onvrijwillige - werkloosheid;

- baan-baan mobiliteit naar functies buiten de zorg- en welzijnssector.

\section{Afbakening en aggregatieniveau informatie}

Het werkterrein van de sector zorg en welzijn is zeer breed en diffuus, waardoor iedere definitie en afbakening van deze sector al op voorhand discutabel is. Volgens het platform zou de indeling betrekking moeten hebben op de sector zorg en welzijn, zoals afgebakend in de daarvoor relevante CAO's. Het betreft hier de CAO's voor de bejaardentehuizen, de dagverblijven en tehuizen voor gehandicapten, de thuiszorg, de jeugdhulpverlening, en voor het welzijnswerk. Hierbij wordt opgemerkt dat een deel van de sociaal-agogische beroepsbeoefenaren bij werkgevers werkzaam is die niet tot deze vijf CAO's behoren. Zo zijn er maatschappelijk werkers en sociaal-pedagogen in het ziekenhuiswezen of bij justitie werkzaam. Voor een goed inzicht in de arbeidsmarktontwikkelingen in de sociaalagogische beroepssectoren is het derhalve van belang dat ook de ontwikkelingen buiten de zorg- en welzijnssector in strikte zin in kaart worden gebracht. De bedrijfstakindeling van het CBS, waaraan het ROA haar gegevens voor het 
informatiesysteem aan ontleent komt overigens niet geheel overeen met de branche-indeling op basis van de CAO's.

Pas sinds kort zijn op landelijk niveau voor de zorg- en welzijnssector op basis van de in de sector gehanteerde functienamen en functieomschrijvingen een drietal op elkaar aansluitende profielen voor beroependomeinen geformuleerd (zie Hens e.a., 1994, 1995). Het gaat hier om de domeinen sociaal-pedagogisch werk, maatschappelijk werk en dienstverlening en sociaal-cultureel werk. Daarnaast zijn de domeinen verpleging en verzorging in dit werkveld - in brede zin - relevant. Voor de afbakening van deze laatste twee domeinen zijn in de sector zorg en welzijn nog geen landelijke kaders geformuleerd. De stuurgroep is hierbij - voor zover voorhanden - speciaal geïnteresseerd in arbeidsinformatie over beroepsbeoefenaren in het domein 'sociaal-pedagogisch werk'.

Met het formuleren van deze in totaal vijf beroependomeinen probeert men binnen en buiten de sector een eenduidige afbakening van het beroepenveld voor de sector zorg en welzijn tot stand te brengen. Nu nog komt het nog zeer regelmatig voor dat functies in zowel het sociaal-pedagogische als sociaal-culturele of verzorgende domein onder het beroep 'groepsleider' worden gerangschikt. Dit komt niet alleen voor in beroepenclassificaties van bijvoorbeeld het CBS, maar ook in registraties van bijvoorbeeld de BVG ten behoeve van het bijhouden van het ziekteverzuim of bij de personeels- en salarissystemen van RAET. Ook in de personeelsinformatie-systemen van de werkgevers in de zorg- en welzijnssector zelf worden functies uit de verschillende domeinen nogal eens onder dezelfde beroepscategorie gerangschikt.

In dit verband is het goed om nog eens te wijzen op het verschil tussen (beroeps)domeinen, beroepen en functies, zoals ook Hover (1995) voor de zorg en welzijnssector heeft aangegeven. Een (beroeps)domein heeft betrekking op een deelgebied van de sector zorg en welzijn en bestaat uit een geheel van verwante diensten, hoofd-, deel- en neventaken en functies. Een taak is hierbij een gerubriceerde opsomming van de verschillende activiteiten die iemand in het kader van zijn functie moet verrichten. Een functie is een geheel van taken die in een bepaalde organisatie in principe door één persoon wordt verricht. Een functie is organisatiegebonden vorm van beroepsarbeid. De sector zorg en welzijn kent ongeveer 150 verschillende (sociaal-agogische) functiebenamingen en beschrijvingen. Een beroep betreft een geheel van met elkaar samenhangende (kern)taken en verantwoordelijkheden, op basis van gemeenschappelijke ethische en kenmerkende theoretische uitgangspunten en beroepsmethodieken, waarvan de aard en de onderlinge samenhang onafhankelijk zijn van de concrete werksituatie. 


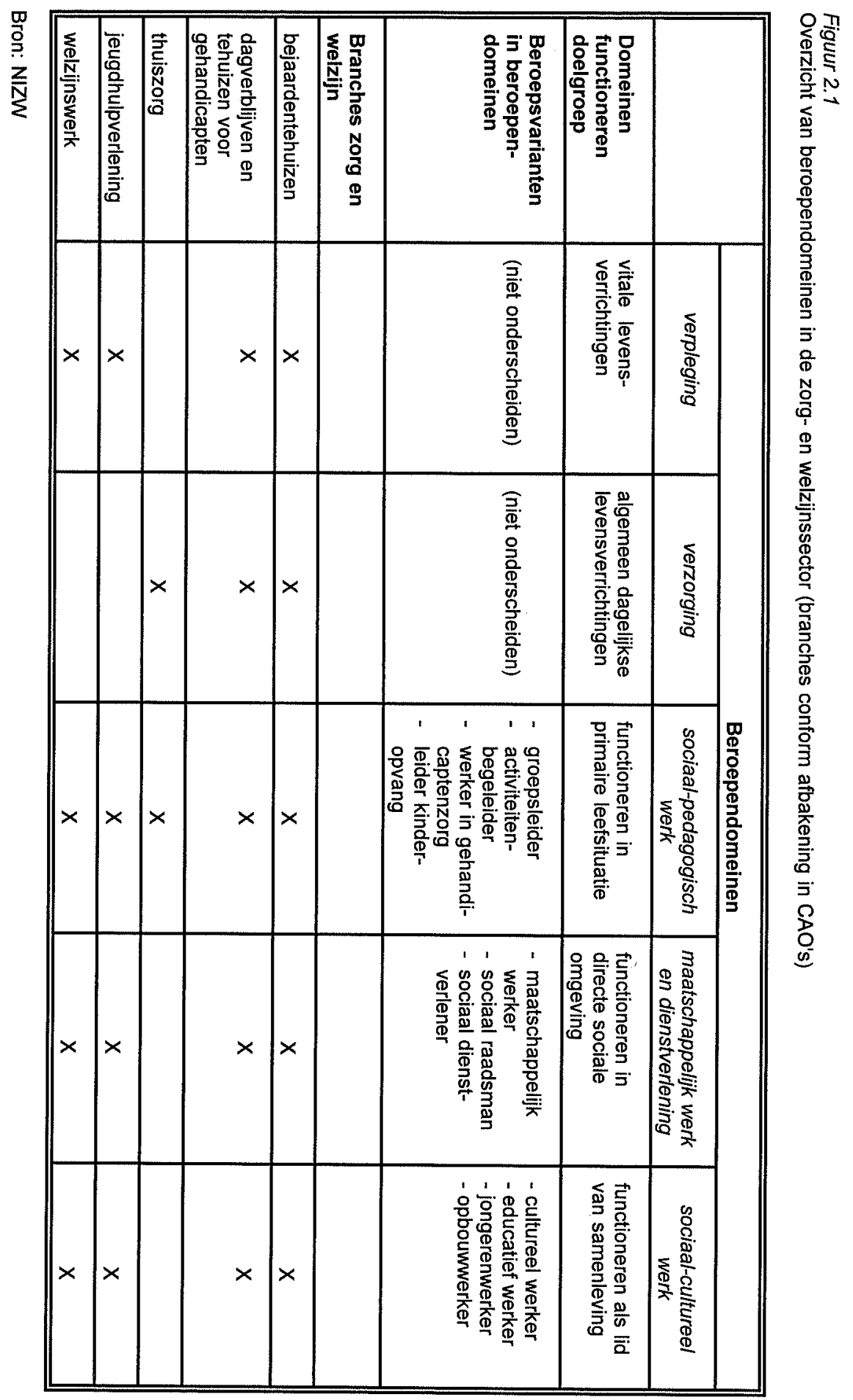


Bij deze indeling in vijf domeinen speelt verder mee dat met name de domeinen verpleging en verzorging niet alleen voor de sector zorg en welzijn, afgebakend volgens de daarvoor geldende CAO's, relevant zijn, maar dat deze domeinen ook andere branches betreffen zoals de gezondheidszorg. Voor een optimaal gebruik van deze domeinindeling in arbeidsmarktonderzoek is het van groot belang dat ook de beroepen in de andere sectoren waarvoor deze domeinen relevant zijn conform dit domeinprincipe ingedeeld zijn (of kunnen worden).

In figuur 2.1 is een overzicht van deze beroependomeinen en branches opgenomen, waarbij men in één oogopslag kan waarnemen welke beroependomeinen in welke branches relevant zijn. Ook is in dit overzicht aangegeven op welke handelingsdomeinen van de betreffende doelgroepen de (sociaal-agogische) beroepsbeoefenaren zich richten. Deze beroependomeinen bevatten een groot aantal beroepen, waaronder op hun beurt weer een groot aantal functiebenamingen en functieomschrijvingen worden gerangschikt.

\section{Representativiteit en vergelijkbaarheid}

De in de arbeidsmarktverkenning opgenomen - anonieme - arbeidsmarktgegevens dienen niet alleen valide, betrouwbaar en consistent te zijn, maar tevens representatief voor de totale populatie in het betreffende beroep, opleidingstype en de sector.

De verzamelde en verwerkte gegevens dienen zodanig geordend en ingedeeld te zijn dat de resultaten uit de' diverse bronnen onderling - intern - goed vergelijkbaar zijn, terwijl ook een goede vergelijking mogelijk is met externe vaak, binnen en buiten de sector, geraadpleegde databronnen.

\section{Actualiteit en periodiciteit}

Vanwege de snelle ontwikkelingen op de arbeidsmarkt en het door beleidsmakers optimaal kunnen reageren op deze dynamische ontwikkelingen, is het van belang dat gegevens over de processen op de arbeidsmarkt snel beschikbaar zijn. Dit geldt in versterkte mate voor indicatoren die de conjuncturele arbeidsmarktontwikkelingen in kaart brengen, zoals informatie over vacatures en werkloosheid.

Informatie over structurele ontwikkelingen op de arbeidsmarkt is minder snel verouderd. Voor het in kaart brengen van trends en structurele processen op de arbeidsmarkt is het van belang dat het geen eenmalige, doch periodieke (bijvoorbeeld jaarlijkse) gegevens betreft. Zo kunnen tijdreeksanalyses worden uitgevoerd, die de basis vormen van (middel)lange termijn arbeidsmarktprognoses. 


\section{Presentatievormen}

De informatie in de verkenning dient snel inzichtelijk te zijn. Doorgaans zijn grafieken inzichtelijker en beklijft de daarin opgenomen informatie beter dan bij tabellen het geval is. Het voordeel van tabellen is evenwel de bondige wijze waarop meerdere indicatoren kunnen worden samengevat.

Gegeven de huidige doelgroep van beleidsmakers is het van belang dat het rapport zowel een inhoudelijke beschrijving geeft van de arbeidsmarktontwikkelingen die zich in de sector zorg en welzijn (zullen gaan) voordoen, als een sterk beknopte methodisch-technische toelichting op de gehanteerde definities en classificaties bevat. Mocht men op termijn de doelgroep willen verbreden waarvoor deze arbeidsmarktinformatie wordt samengesteld, dan ligt het voor de hand om ook de presentatievormen daarop verder aan te passen.

\subsection{Beschikbare informatie}

Zoals gezegd was al bij de start van dit pilot-onderzoek bekend dat op dit moment geen landelijke en periodiek verzamelde arbeidsmarktgegevens voorhanden zijn die geheel in de informatiebehoeften van het platform kunnen voorzien. Zo is op het lage aggregatieniveau van de sociaal-pedagogische werkers en opleidingen alleen informatie beschikbaar voor de starters op de arbeidsmarkt (de schoolverlaters) en niet voor de gehele beroepsbevolking. Daarnaast zijn de resultaten van het werkgeversonderzoek in de sociaal-agogische sector alleen beschikbaar uit een eenmalig onderzoek dat in 1991 in Noord-Nederland heeft plaatsgevonden. Alles bij elkaar genomen zijn er weliswaar veel gegevens over de arbeidsmarktsituatie in de zorg en welzijnssector, maar vormt het tezamen een 'te grove lappendeken'.

Om de bruikbaarheid van deze arbeidsmarktgegevens te bepalen, is besloten om de beschikbare informatie in deze arbeidsmarktverkenning op overzichtelijke en samenhangende wijze te presenteren, om vervolgens aan te kunnen geven op welke punten de informatievoorziening verbeterd dient te worden om - op termijn beter in de informatiebehoefte te kunnen voorzien.

De volgende drie gegevensbronnen vormen de basis van deze arbeidsmarktverkenning:

- informatiesysteem onderwijs-arbeidsmarkt;

- Schoolverlatersonderzoeken RUBS en HBO-Monitor;

- Panelonderzoek onder werkgevers in de zorg- en welzijnssector in NoordNederland. 
Informatiesysteem ondenwijs-arbeidsmarkt

Het informatiesysteem onderwijs-arbeidsmarkt is door het ROA een aantal jaren geleden als een zogenaamd stroommodel ontwikkeld en wordt nu verder uitgebouwd. Het systeem heeft tot doel aan de hand van jaarlijkse kengetallen, trends en prognoses, inzicht te verschaffen in de huidige en toekomstige positie van beroepsbeoefenaren, onderscheiden naar 13 sectoren, 93 beroepsklassen en 79 opleidingstypen. De prognoses in het informatiesysteem hebben betrekking op de verwachte arbeidsmarktontwikkelingen op de middellange termijn (vijjarige prognoseperiode van 1995 tot het jaar 2000), terwijl de actuele arbeidsmarktgegevens de periode 1990 - 1994 betreffen.

Het systeem wordt gevoed door verder bewerkte gegevens uit bestaande databronnen. $\mathrm{Er}$ is hierbij in belangrijke mate gebruik gemaakt van de informatie over de werkzame beroepsbevolking uit Enquête Beroepsbevolking (EBB) van het Centraal Bureau voor de Statistiek (CBS). Bovendien zijn de prognoses consistent met de prognoses die het Centraal Planbureau (CPB) voor de verschillende bedrijfssectoren heeft opgesteld met betrekking tot de werkgelegenheidsontwikkeling op de middellange termijn, en met de Referentieramingen van het Ministerie van Onderwijs, Cultuur en Wetenschappen over de in de toekomst verwachte uitstroom uit het initiële onderwijs.

Vanwege het gebruik van EBB-gegevens voor het informatiesysteem is de gehanteerde ROA-Beroepenclassificatie gebaseerd op de CBS Beroepenclassificatie 1984, waarbij een clusteranalyse op de ruim 300 CBS-beroepsgroepen heeft geresulteerd in 93 ROA-beroepsklassen. Deze 93 ROA-beroepsklassen sluiten beter aan op de huidige arbeidsmarktsegmentatie dan de 82 CBSberoepsklassen.

Bij aanvang van dit pilot-onderzoek is met de stuurgroep afgesproken in de arbeidsmarktverkenning alleen informatie op te nemen over de ROA-beroepsklasse van maatschappelijk en cultureel werkers (7033), waarvan het resultaat steeds wordt vergeleken met het resultaat over het totaal van alle beroepsbeoefenaren. Van alle ROA-beroepsklassen sluit deze namelijk het beste aan bij het domein van de sociaal-pedagogisch werkers in de zorg- en welzijnssector (zie ook paragraaf 3.1 en bijlage 3 en 4). Het gaat hier overigens nog altijd over een breed samengestelde groep beroepsbeoefenaren, waarin de in hoofdstuk 1 onderscheiden beroependomeinen 'sociaal-pedagogisch werk', 'maatschappelijk werk en dienstverlening' en 'sociaal-cultureel werk' alle drie zijn vertegenwoordigd. De beroependomeinen 'verpleging' en 'verzorging' vindt men met name in de ROAberoepsklassen van de verpleegkundigen (5021) en van de leerling- 
verpleegkundigen, zieken- en kraamverzorgenden (5022), evenals van de kinder-, gezins- en bejaardenverzorgenden (8212) terug. ${ }^{1}$

Zoals gezegd, hecht de stuurgroep er aan dat de arbeidsmarktinformatie - op termijn - tot op het niveau van deze vijf beroependomeinen kan worden verstrekt. In het bijzonder zou het hierbij dan gaan om degenen die in de sociaal-pedagogische hulpverlening werkzaam zijn, welke is gericht op de verzorging en begeleiding van mensen ten behoeve van het beter functioneren van mensen in de primaire leefsituatie. Het betreft hier een nieuw samengestelde groep van beroepen en functies waarin onder andere (coördinerende) groeps- en unitleiders, activiteiten(bege)leiders, pedagogisch medewerkers, hulpverleners in opvangcentra en inrichtingswerkers opgenomen zijn.

De arbeidsmarktgegevens uit het informatiesysteem worden ook onderscheiden naar zo'n tachtig opleidingstypen. Het gaat hier om informatie over beroepsbeoefenaren die met een bepaalde opleidingsachtergrond werkzaam (willen) zijn op de arbeidsmarkt. Ook bij deze arbeidsmarkt-informatie dient het ROA, vanwege het gebruik van de EBB-gegevens, uit te gaan van de indeling die het CBS hiervoor hanteert, in casu de Standaard Onderwijs Indeling (SOI; zie ook bijlage 3 en 4). Het gaat hier om het hoogst genoten onderwijs van de betreffende beroepsbeoefenaren. Voor dit pilot-onderzoek zijn de volgende categorieën relevant: MBO sociaal-cultureel, $\mathrm{MBO}^{2}$ verzorgend en $\mathrm{HBO}$ sociaal-cultureel. De sociaalpedagogische opleidingen vormen een (substantieel) onderdeel binnen deze sociaal-culturele opleidingen.

\section{Schoolverlatersonderzoeken}

De arbeidsmarktverkenning bevat ook de gegevens van de grootschalige jaarlijkse schoolverlatersonderzoeken die het ROA sinds enkele jaren zelf uitvoert. Deze onderzoeken geven voor het betreffende moment inzicht in de vraaglaanbodverhouding voor starters op de arbeidsmarkt, en betreffen dus niet alleen de ontwikkelingen aan de aanbodzijde van de arbeidsmarkt, zoals nog wel eens wordt verondersteld.

1. Voor uitgebreide arbeidsmarktinformatie over de beroepsklassen van verpleegkundigen, leerlingverpleegkundigen en verzorgenden (inclusief zwakzinnigenverzorgenden, gediplomeerd en in opleiding) wordt $u$ verwezen naar (de statistische bijlage van) het rapport 'De arbeidsmarkt naar opleiding en beroep tot 2000' (1995) en het rapport 'Toekomstverkenning arbeidsmarkt zorgsector' (1994).

2. Het opleidingstype MBO verzorgend bevat niet alleen gegevens over beroepsbeoefenaren die een initiële MBO-opleiding hebben (als hoogste opleiding) voltooid maar ook over degenen die in één van de verzorgende inservice-opleidingen het diploma hebben behaald. 
Het betreft enkele grootschalige schoolverlatersonderzoeken die het ROA jaarlijks uitvoert. Bij het project RUBS (Registratie van de Uitstroom en Bestemming van Schoolverlaters) gaat het om het onderzoek dat medio 1994 heeft plaatsgevonden onder de schoolverlaters van het algemeen voortgezet onderwijs en het voorbereidend, middelbaar en beroepsbegeleidend onderwijs, welke een jaar daarvoor het diploma hebben behaald (studiejaar 1992/1993). Daarnaast is eind 1994 / begin 1995 de HBO-Monitor uitgevoerd, een vergelijkbaar onderzoek onder de afgestudeerden van het hoger beroepsonderwijs die circa anderhalf jaar daarvoor zijn afgestudeerd (eveneens studiejaar 1992/1993). In beide onderzoeken gaat het in feite om de starters op de arbeidsmarkt. Overigens wel een groep waarbij nieuwe arbeidsmarkt- en beleidsontwikkelingen doorgaans als eerste waarneembaar zijn.

De beroepen-, branche- en opleidingenclassificaties die het ROA voor deze schoolverlatersonderzoeken hanteert is weliswaar gebaseerd op de beroepenclassificaties die het CBS hanteert, maar deze zijn wel verder verfijnd en kunnen naar verhouding gemakkelijk worden aangepast. Hierdoor is arbeidsmarktinformatie mogelijk op een lager, gedetailleerder, aggregatieniveau en kan beter worden aangesloten bij beter herkenbare beroependomeinen. De beroepenindeling zoals die voor het onderzoek onder de afgestudeerden van het HBO wordt gehanteerd onderscheidt de beroepen zelfs op een gedesaggregeerder niveau dan de in hoofdstuk 1 aangegeven vijf beroependomeinen in de zorg- en welzijnssector.

De arbeidsmarktinformatie over de voor deze sector relevante opleidingen betreft de sociaal-agogische opleidingen op MBO- en HBO-niveau, die mensen opleiden voor onder andere het beroep van sociaal-pedagogisch werker. Op MBO-niveau betreft het de $\mathrm{MDGO}^{3}$-opleidingen agogisch werk, activiteitenbegeleiding, verzorging en sociale arbeid. Op HBO-niveau gaat het zowel om gegevens over het totale hoger sociaal-agogisch onderwijs (HSAO) als om de opleiding sociaal-pedagogische hulpverlening (SPH) daarbinnen, welke is ontstaan uit de voormalige HBOopleidingen inrichtingswerk, jeugdwelzijnswerk en (een deel van) creatief-educatief werk.

\section{Werkgeversonderzoek zorg- en welzijnssector Noord-Nederland}

In dit pilot-onderzoek zijn ook gegevens opgenomen uit een in 1991 (tot op heden eenmalig uitgevoerd) onderzoek onder werkgevers in de zorg-en welzijnssector in Noord-Nederland. Dit onderzoek gaf voor iedere deelnemende werkgever in deze

3. MDGO staat voor Middelbaar Dienstverlenend Gezondheidszorg Onderwijs. 
sector inzicht in de in-, door- en uitstroom van sociaal-agogische beroepsbeoefenaren, waardoor het personeelsverloop (en daarmee de bruto vervangingsvraag), evenals de werkgelegenheidsontwikkeling in deze organisaties in dat jaar kon worden vastgesteld. Het werkgeversonderzoek gaf verder een beeld van het wervings-, selectie, en scholingsbeleid van de onderzochte werkgevers, onderverdeeld naar zorg- en welzijnswerkinstellingen, en kenmerken zoals de grootte van de instelling e.d.

Het gaat hier om een zogenaamd panelonderzoek. Hierbij wordt een representatieve groep werkgevers periodiek benaderd. Doordat steeds dezelfde groep wordt geënquêteerd ontstaat er een continue informatiestroom die een goed inzicht kan bieden in de werkgelegenheidsontwikkeling in de betreffende instellingen. Bij cross-sectioneel onderzoek, waarbij steeds een nieuwe groep werkgevers wordt benaderd, kan men niet zien of de geconstateerde veranderingen zijn toe te schrijven aan een bepaalde trendmatige ontwikkeling of een gevolg zijn van het feit dat bij herhaalde metingen de de steekproef van werkgevers steeds anders is.

De beroepen-, branche- en opleidingenindeling die voor dit werkgeversonderzoek is gehanteerd sluit redelijk tot goed aan bij de eerder in hoofdstuk 1 genoemde vijf beroependomeinen, waarbij de sociaal-pedagogisch hulpverleners, maatschappelijk werkers en leidinggevenden in de zorg- en welzijnssector ieder afzonderlijk zijn onderscheiden. Het totaal van sociaal-agogisch personeel omvatte in dit werkgeversonderzoek eveneens de beroepscategorieën cultureel werkers, beleidsmedewerkers en personeelswerkers voor zover in de zorg- en welzijnssector werkzaam.

\section{Gehanteerde beroeps- en opleidingscategorieën}

In concreto betekent bovenstaande voor de in deze pilot-verkenning te presenteren arbeidsmarktinformatie het volgende (zie tabel 2.2 en 3.1c). Op het niveau van de totale werkzame Nederlandse beroepsbevolking wordt steeds voor de volgende beroeps- en opleidingscategorieën arbeidsmarktinformatie verstrekt. In tabel $2.2 \mathrm{a}$ staat het absoluut aantal beroepsbeoefenaren dat tot bepaalde beroepslopleidingscategorie behoort. De tabellen en grafieken in hoofdstuk 3 en 4 over de totale beroepsbevolking hebben steeds op deze zogenaamde $\mathrm{N}$-aantallen betrekking. 
Tabel 2.2a

Absoluut aantal beroepsbeoefenaren in de totale Nederlandse beroepsbevolking naar sociaalagogische beroeps-/opleidingscategorieën (gemiddelde 1993/1994; afgerond op 500-tallen)

Aantal in werkzame

beroepsbevolking

Beroeps-/opleidingscategorie

Totaal beroepsbeoefenaren

- w.v. maatschappelijk en cultureel werkers

5.885 .500

68.000

- w.v. met MBO-opleiding

- w.v. met verzorgende opleiding

- w.v. met sociaal-culturele opleiding

- w.v. met HBO-opleiding

- w.v. met sociaal-culturele opleiding

285.500

212.000

52.500

1.022 .000

118.000

Bron: CBS (EBB) / ROA

Op het niveau van de (werkende) starters op de arbeidsmarkt (in casu de Nederlandse schoolverlaters), wordt steeds, per sociaal-agogische opleidingscategorie, over de volgende aantallen gediplomeerden arbeidsmarktinformatie verstrekt.

Tabel $2.2 b$

Absoluut aantal (werkende) gediplomeerden van MBO en HBO naar sociaal-agogische opleidingscategorieën (studiejaar 1992/1993; afgerond op 10-tallen)

\begin{tabular}{|c|c|c|c|}
\hline & $\begin{array}{l}\text { Populatie } \\
\text { Aantal } \\
\text { gedipl. }\end{array}$ & $\begin{array}{l}\text { Onderzoek } \\
\text { Aantal } \\
\text { gedipl. }\end{array}$ & $\begin{array}{l}\text { Aantal } \\
\text { werkenden }\end{array}$ \\
\hline \multicolumn{4}{|l|}{ Opleidingscategorie } \\
\hline $\begin{array}{l}\text { Totaal met MBO } \\
\text { - } \quad \text { w.v. met MDGO } \\
\text { - } \text { w.v. met agogisch werk } \\
\text { - } \text { w.v. met verzorging } \\
\text { - } \quad \text { w.v. met activiteitenbegeleiding } \\
\text { - } \quad \text { w.v. met sociale arbeid }\end{array}$ & $\begin{array}{r}55.890 \\
14.720 \\
3.540 \\
3.120 \\
890 \\
660\end{array}$ & $\begin{array}{r}9.620 \\
3.780 \\
1.040 \\
860 \\
250 \\
140\end{array}$ & $\begin{array}{r}4.780 \\
2.290 \\
520 \\
680 \\
160 \\
40\end{array}$ \\
\hline $\begin{array}{l}\text { Totaal met HBO } \\
-\quad \text { w.v. met HSAO } \\
-\quad \text { w.v. met sociaal-pedagogische } \\
\quad \text { hulpverlening }\end{array}$ & $\begin{array}{r}42.240 \\
5.700 \\
1.800\end{array}$ & $\begin{array}{r}12.810 \\
1.750 \\
580\end{array}$ & $\begin{array}{r}9.340 \\
1.410 \\
490\end{array}$ \\
\hline
\end{tabular}

Bron: Min. OCW (ILT \& CRIHO) / ROA (RUBS / HBO-Monitor)

In tabel 2.2b wordt eerst het totaal aantal gediplomeerden genoemd dat in het studiejaar 1992/1993 in Nederland het diploma heeft behaald. Deze gegevens over het aantal gediplomeerden uit de diverse opleidingscategorieën zijn ontleend aan gegevens van het Ministerie van Onderwijs, Cultuur en Wetenschappen. Voor het 
MBO betrof dit de Integrale Leerlingtelling (ILT) en voor het HBO het Centraal Register Inschrijvingen Hoger Onderwijs (CRIHO). Het betreft hier de populatie waarop zowel RUBS als HBO-Monitor 1994 betrekking hebben. Vervolgens is in de tweede kolom van tabel $2.2 \mathrm{~b}$ het absoluut aantal gediplomeerden van MBO en HBO vermeld dat heeft deelgenomen aan het schoolverlatersonderzoek. In de laatste kolom staat het absoluut aantal schoolverlaters dat in het onderzoek heeft aangegeven minimaal 12 uur per week betaald werk te verrichten.

Voor de zorg- en welzijnsinstellingen in Noord-Nederland wordt arbeidsmarktinformatie gepresenteerd over de volgende absolute aantallen beroepsbeoefenaren, onderverdeeld naar enkele relevante beroepscategorieën.

Tabel $2.2 c$

Absoluut aantal sociaal-agogisch personeel dat bij werkgevers in zorg-en welzijnssector in Noord-Nederland werkzaam was (voor zover deelname werkgever aan onderzoek), per beroepscategorie, eind 1991 (afgerond op 10-tallen)

Aantal beroepsbeoefenaren in onderzoek

\section{Beroepscategorie}

Totaal sociaal-agogisch personeel

- w.v. sociaal-pedagogisch hulpverleners

- w.v. maatschappelijk werkers

1.420

w.v. leidinggevenden zorg/welzijn

Bron: ROA

Het gaat hier om het totaal aantal sociaal-agogische beroepsbeoefenaren in de onderzochte zorg- en welzijnsorganisaties in Noord-Nederland zoals deze organisaties in dit werkgeversonderzoek voor eind 1991 hebben aangegeven. De aantallen betreffen alleen de onderzoekseenheden. Het was niet goed mogelijk deze aantallen terug te rekenen naar de totale populatie van sociaal-agogisch personeel in de zorg-en welzijnssector in Noord-Nederland.

De percentages in de grafieken en tabellen in hoofdstuk 3 en 4 zijn zo goed als altijd op de in tabel 2.2 genoemde aantallen werkenden gebaseerd ${ }^{4}$. Om de

4. Exclusief de zogenaamde 'user missing values'. Het gaat hier om personen die weliswaar tot de betreffende categorie behoren, maar die geen informatie hebben verschaft met betrekking tot een bepaalde arbeidsmarktindicator. Daarnaast zijn de gegevens over het potentiële aanbod (paragraaf 3.2.1) en over de werkloosheid (paragraaf 3.2.3) onder de schoolverlaters op een bredere groep gebaseerd. Zo zijn de werkloosheidspercentages berekend op de schoolverlaters die zich hebben aangeboden op de arbeidsmarkt: de beroepsbevolking. 
informatie in de grafieken en tabellen zo overzichtelijk mogelijk te presenteren zijn deze zogenaamde $\mathrm{N}$-aantallen, waarbij de verschillen voor de betreffende categorie werkenden slechts marginaal zijn, in de rest van het rapport achterwege gelaten.

\subsection{Mismatch benodigde en beschikbare informatie}

In deze paragraaf wordt uiteengezet op welke punten discrepantie bestaat tussen de benodigde en beschikbare informatiebronnen. In het laatste hoofdstuk, na presentatie van de momenteel beschikbare arbeidsmarktinformatie, worden voorstellen geformuleerd om de databronnen beter toe te snijden op de informatie die door beleidsmakers in de zorg en welzijnssector nodig wordt geacht bij het formuleren van het kwalificatie-, onderwijs-, scholings- en arbeidsmarktbeleid.

Zoals in paragraaf 2.1 reeds aangegeven, wordt de meest volledige (en overzichtelijke) beschrijving van de actuele en toekomstige arbeidsmarktsituatie verkregen aan de hand van een zogenaamd 'stroommodel' van de in-, door- en uitstroom op de arbeidsmarkt in de zorg- en welzijnssector.

In een dergelijk stroommodel worden niet alleen de aantallen werkzame en werkloze personen op een bepaald moment in kaart gebracht (via zogenaamde 'standcijfers'), maar wordt ook de dynamiek van de arbeidsmarkt weergegeven voor de onderscheiden periode. Ook het informatiesysteem onderwijs-arbeidsmarkt van het ROA is conform de methodiek van een stroommodel opgezet. De gegevens in hoofdstuk 3 en 4 zijn, met uitzondering van de informatie uit de schoolverlatersonderzoeken, eveneens aan dit informatiesysteem ontleend en betreffen derhalve eveneens stroomcijfers.

Verder dient het informatiemodel over de arbeidsmarkt in de zorg-en welzijnssector (idealiter) aan de volgende eisen te voldoen (zie ook paragraaf 2.1):

- beleidsmatige informatie genererend voor sociale partners, koepelorganisaties, (landelijke) overheden en arbeidsvoorziening en het georganiseerde onderwijsveld;

- informatie heeft betrekking op de actuele en toekomstige stromen op de arbeidsmarkt in de zorg- en welzijnssector. Kwantitatieve en kwalitatieve indicatoren betreffen zowel de vraag- als aanbodzijde;

- informatie is representatief voor gehele Nederlandse (werkende) beroepsbevolking, onderscheiden naar de relevante categorieën;

- sectorindeling sluit aan op de afbakening van de CAO's, en de beroepenindeling op de indeling van beroependomeinen die het platform hanteert; de beroepscategorie van sociaal-pedagogisch werkers moet afzonderlijk onderscheiden (kunnen) worden; 
- informatie dient gebaseerd te zijn op bestaande, actuele en jaarlijkse/periodieke gegevensbronnen, waarbij interne en externe vergelijkbaarheid is gewaarborgd;

- heldere en duidelijke presentatie gegevens, zodat de geboden informatie inzichtelijk is.

Wanneer de tot op heden (bij het ROA) beschikbare gegevens worden vergeleken met de hierboven geschetste informatiebehoefte van het platform, blijkt dat er weliswaar veel informatie over de arbeidsmarktsituatie in de zorg en welzijnssector voor handen is, maar bij elkaar een soort 'lappendeken' vormt. De crux zit hem in de juiste combinatie van gehanteerde definties en classificaties, de afgebakende populatie, het eenmalige of periodieke karakter van het onderzoek, de inhoud en tijdshorizon van de kengetallen, indicatoren en prognoses en 'last but not least' het gehanteerde aggregatieniveau.

Indien landelijke representativiteit en actualiteit harde randvoorwaarden zijn, en de gegevens de gehele Nederlandse (werkzame) beroepsbevolking dienen te betreffen, zoals bij het ROA-informatiesysteem het geval is, dan voldoet de op dit momemt beschikbare informatie met name niet op het punt van het gewenste aggregatieniveau. De beschikbare informatie is te grofmazig. En in een aantal gevallen komt de afbakening niet overeen met de door het platform gewenste afbakening van sectoren en beroepscategorieën.

Voor het bepalen van de actuele en toekomstige stromen in de zorg- en welzijnssector is bij het ROA-informatiesysteem voor een belangrijk deel gebruik gemaakt van de EBB-gegevens (CBS) over de werkzame beroepsbevolking. Voordeel van het gebruik van de EBB voor het in kaart brengen van deze arbeidsmarktstromen is dat deze de gehele arbeidsmarkt en beroepsbevolking betreft. Nadeel is echter dat met name de gehanteerde indelingen voor bedrijfstakken, beroepen en opleidingen niet aansluiten bij de indelingen zoals deze voor het platform het beste bruikbaar zijn.

Mismatch informatiesysteem t.a.v. branches zorg- en welzijnssector

Voor de weergave van arbeidsmarktgegevens naar sector maakt het ROA gebruik van de standaard bedrijfsindeling (SBI) van het $\mathrm{CBS}$ en de bedrijfstakkenindeling van het $\mathrm{CPB}$. Beide indelingen sluiten niet geheel aan op de indeling van de voor de zorg- en welzijnssector relevante CAO's (zie o.a. Heikoop, 1996). Het CBS beschikt overigens wel over statistische branche-informatie op een zeer laag aggregatieniveau, zodat het in principe mogelijk is de CBS-gegevens in belangrijke mate te koppelen aan de betreffende CAO-indeling. Aangezien het aantal beroepsbeoefenaren dat onder de betreffende CAO's werkt voldoende groot is, 
wordt ook tegemoet gekomen aan de door het CBS gestelde ondergrens van circa $2.500-5.000$ beroepsbeoefenaren voor het verkrijgen van arbeidsmarktinformatie.

\section{Mismatch informatiesysteem t.a.v. sociaal-agogische beroepen}

Zo is de arbeidsmarktsituatie voor het beroependomein van sociaal-pedagogisch werkers niet afzonderlijk in kaart te brengen. De beroepeninformatie uit de EBB is in de eerste plaats op een te hoog niveau geaggregeerd om voor het platform optimale informatie te kunnen genereren. Dit heeft in de eerste plaats te maken met het feit dat de EBB een steekproeffractie kent van $1 \%$, hetgeen te laag is om de informatie op een zeer laag aggregatieniveau te kunnen weergeven. Het CBS hanteert hiervoor een ondergrens van circa $2.500-5.000$ beroepsbeoefenaren voor het presenteren van informatie. Toch is het dat niet alleen, de beroepsklasse van maatschappelijk en cultureel werkers is met 68.000 beroepsbeoefenaren namelijk groot genoeg om verder uit te splitsen in bijvoorbeeld de domeinen sociaalpedagogisch werk, maatschappelijk werk en dienstverlening en sociaal-cultureel werk zoals door het NIZW (in opdracht van het platform) is voorgesteld.

Echter de beroepenclassificatie van het CBS is ook op het laagste aggregatieniveau hiervoor niet voldoende gedetailleerd. Het is ook bijzonder spijtig dat het CBS bij het opstellen van haar nieuwe beroepenclassificatie geen rekening heeft gehouden met de indeling zoals deze in de sector zelf wordt gehanteerd. Het resultaat is nu dat de nieuwe beroepenclassificatie van het $\mathrm{CBS}$, de SBC'92, ondanks een aanzienlijke verfijning voor het sociaal-agogisch personeel, desondanks niet goed is toegesneden op een voor het werkveld herkenbare indeling (zie ook de CBO-notitie uit 1994 van $F$. Peters over een vergelijking van de Beroepenstructuur en de Standaard Beroepenclassificatie 1992). In bijlage 6 is voor de vijf beroependomeinen zoals door het NIZW onderscheiden aangegeven welke CBSberoepen daartoe gerekend kunnen worden. Dit overzicht wordt zowel voor de CBS-classificatie uit 1984 gepresenteerd als voor de SBC'92.

Mismatch informatiesysteem t.a.v. sociaal-agogische opleidingen

Voor het weergeven van arbeidsmarktinformatie naar de opleidingsachtergrond van de werkende beroepsbevolking, maakt het ROA gebruik van de standaard onderwijsindeling (SOI) van het CBS. Sinds kort is het voor het ROA mogelijk om, mede in combinatie met de gegevens uit de schoolverlatersonderzoeken, de arbeidsmarktinformatie uitgesplitst naar opleidingstypen op een aanzienlijk lager 
aggregatieniveau te presenteren. Het afgelopen jaar zijn met name de technische en economische opleidings-richtingen verder uitgesplitst. ${ }^{5}$

Naast bovengenoemd landelijk representatief informatiesysteem over de totale Nederlandse (werkzame) beroepsbevolking, zijn er een aantal gegevensbronnen die - op een laag aggregatieniveau - informatie bieden over arbeidsmarktontwikkelingen in de zorg- en welzijnssector.

\section{Mismatch schoolverlatersonderzoeken}

Op dit moment bestrijken de hierboven genoemde schoolverlatersonderzoeken momenteel nog niet de volle breedte van het opleidingen- en beroepenveld. Dit heeft tot gevolg dat de arbeidsmarktinformatie uit deze schoolverlatersonderzoeken nog niet onderscheiden kan worden naar beroep. De beroepsgroep van bijvoorbeeld bedrijfsmaatschappelijk werkers bevat namelijk niet degenen die met een academische opleiding in deze beroepsgroep terecht zijn gekomen, omdat in de schoolverlatersonderzoeken deze afgestudeerden nog niet zijn vertegenwoordigd. Wanneer binnenkort de WO-Monitor op landelijke schaal toegepast gaat worden, is het wel mogelijk de (actuele) vraag-/aanbodverhouding voor het totale beroepenveld in kaart te brengen. Op dat moment is de arbeidsmarktinformatie uit de schoolverlatersonderzoeken niet alleen representatief voor alle middelbare en hogere voortgezette opleidingen in Nederland, maar kan de arbeidsmarktinformatie ook zinvol worden onderscheiden naar beroepscategorie, op ieder gewenst aggregatieniveau. Echter, zo lang loopbaanmetingen niet structureel worden verricht, gaat het dan nog steeds om de marktpositie van schoolverlaters, in casu de starters op de arbeidsmarkt.

\section{Mismatch werkgeversonderzoek}

Het panelonderzoek dat het ROA in 1991 heeft uitgevoerd onder de werkgevers in de zorg- en welzijnssector in de drie noordelijke provincies, heeft waardevolle informatie opgeleverd over het personeelsverloop van sociaal-agogisch personeel op micro-niveau. Verder heeft dit panelonderzoek veel informatie opgeleverd over enkele structuurkenmerken van de branche, evenals informatie over de werving en selectie van sociaal-agogisch personeel en het scholings- en loopbaanbeleid ten opzichte van deze categorie werknemers. Ook de in dit onderzoek gehanteerde

5. Terwijl het informatiesysteem vorig jaar bijvoorbeeld nog uitging van één opleidingstype MBO technisch wordt deze nu onderverdeeld in een elftal opleidingsrichtingen zoals bouwkunde, metaalkunde, elektrotechniek en consumptieve techniek. Een dusdanig gedesaggregeerde opleidingsindeling is in principe ook voor het sociaal-agogisch onderwijs mogelijk. 
indelingen sloten goed aan bij de indelingen die voor het werkveld herkenbaar en goed hanteerbaar zijn. Deze gehanteerde beroepen- en branche-indelingen waren dan ook opgesteld in nauwe samenspraak met vertegenwoordigers van werkgeversverenigingen, onderwijsinstellingen, het Ministerie van Volkgezondheid, Welzijn en Sport (WWS) e.d. Het werkgeversonderzoek dat als een soort panelonderzoek was opgezet, om nu net de ontwikkelingen aan de vraagzijde van de arbeidsmarkt in kaart te brengen, is vooralsnog echter éénmalig uitgevoerd en laat alleen de ontwikkelingen aan de vraagzijde van de arbeidsmarkt zien.

\section{Resumé}

Op dit moment zijn de door het ROA gehanteerde - externe - gegevensbronnen voor haar informatiesysteem dat de totale beroepsbevolking omvat niet voldoende gedesaggregeerd in vergelijking met de informatiebehoefte van het platform. Bovendien komt de afbakening van branches en beroepen niet altijd overeen met de wensen hierover van het platform. Desondanks levert dit informatiesysteem, in combinatie met de gegevens uit andere informatiebronnen zoals de jaarlijks uitgevoerde schoolverlatersonderzoeken en het eenmalig uitgevoerde werkgeversonderzoek voor de zorg- en welzijnssector bruikbare kengetallen op voor het kwalificatie- en aanpalende onderwijs-, scholings- en arbeidsmarktbeleid.

Voor de beroepscategorie van sociaal-pedagogisch werkers wordt het volgende opgemerkt. Aan de ene kant is de arbeidsmarktinformatie over deze beroepscategeorie ondergebracht in de breed samengestelde groep van de maatschappelijk en cultureel werkers tezamen. Aan de andere kant is gedetailleerde arbeidsmarktinformatie over deze groep 'verpakt' aanwezig in de gegevens over met name de starters op de arbeidsmarkt die de opleiding MDGO agogisch of activiteitenbegeleiding of een HBO-opleiding sociaal-pedagogische hulpverlening hebben genoten.

Bij het verder ontwikkelen van een standaard arbeidsmarktverkenning voor de sector zorg en welzijn, kan het beste een strategie "van grof naar fijn" worden gehanteerd. Hierbij gaat het niet in de eerste plaats om het aanvullen van de huidige arbeidsmarktinformatie door het toevoegen van nieuwe indicatoren die een aspect van de arbeidsmarktsituatie in de zorg- en welzijnssector belichten. Veeleer gaat het om het invullen van de bestaande arbeidsmarktinformatie, zodat de kengetallen op een gedetailleerder en voor de sector herkenbaarder aggregatieniveau kunnen worden gepresenteerd. 



\section{Actuele arbeidsmarktsituatie zorg- en welzijnssector}

\subsection{Omvang en samenstelling beroepsbevolking}

\subsubsection{Omvang naar beroeps-en bedrijfsklasse}

In tabel 3.1a is voor een aantal ROA-beroepsklassen het percentage beroepsbeoefenaren weergegeven dat in de zorg- en welzijnssector werkzaam is, wanneer de sector zoveel als mogelijk is ingedeeld conform de in de sector geldende CAO's. Uit tabel 3.1a blijkt dat het met name de maatschappelijk werkers en de kinder-, gezins- en bejaardenverzorgenden zijn, die een functie binnen de zorg- en welzijnssector vervullen.

Tabel 3.1a

Procentuele omvang werkzame beroepsbevolking naar sociaal-agogische, verzorgende en verpleegkundige beroepsklassen en bedrijfsklassen binnen en buiten zorg- en welzijnssector (1994)

\begin{tabular}{ll}
\multicolumn{2}{c}{ Percentage werkenden } \\
$\begin{array}{ll}\text { Binnen } & \text { Buiten } \\
\text { zorg-/welzijn } & \text { zorg-/welzijn }\end{array} \quad$ Totaal
\end{tabular}

\section{Beroepsklassen}

Maatschappelijk en cultureel werkers Kinder-/gezins-/bejaardenverzorgenden

Gediplomeerd verpleegkundigen

Leerling-verpleegkundigen, zwakzinnigen-

zieken- en kraamverzorgenden

Overige beroepsbeoefenaren

$\begin{array}{rrr}58 \% & 42 \% & 100 \% \\ 77 \% & 23 \% & 100 \% \\ 6 \% & 94 \% & 100 \% \\ 19 \% & 81 \% & 100 \% \\ 4 \% & 96 \% & 100 \% \\ 5 \% & 95 \% & 100 \%\end{array}$

$\begin{array}{llll}\text { Totaal beroepsbeoefenaren } & 5 \% & 95 \% & 100 \%\end{array}$

Bron: CBS/ROA

6. Gegeven de afbakening van de CAO's in de zorg- en welzijnssector worden de volgende CBS-bedrijfsgroepen voor dit pilot-onderzoek tot de sector zorg en welzijn gerekend: bejaardentehuizen (SBI 941), tehuizen en dagverblijven voor gehandicapten (geen medische behandeling; SBI 943), kindertehuizen, sociale tehuizen e.d. voor nietgehandicapten (SBI 942), sociaal-medische, sociaal-psychologische en pedagogische diensten (SBI 944), maatschappelijke organisaties (SBI 945), gezinsverzorging en -hulp (946), kinderdagverblijven en crèches (voor gezonde kinderen; SBI 947), buurt- en clubhuiswerk en samenlevingsopbouwwerk (SBI 951) en jeugd- en jongerenwerk (SBI 952); zie ook bijlagen 3 en 4 . In verband met kleine aantallen waarnemingen $(<=2.500$ ) kon soms de verdeling naar beroepsklasse en bedrijfssubgroep niet worden gemaakt, waardoor een lichte onderschatting van het percentage werkenden in de zorg- en welzijnssector mogelijk is. 
Tabel $3.1 b$

Overzicht van relatie tussen subsectoren zorg- en welzijnssector en de beroepsklassen van maatschappelijk en cultureel werkers en kinder-, gezins- en bejaardenverzorgenden (beroepsbevolking, 1994)

\begin{tabular}{cccc}
\multicolumn{3}{c}{ Procentueel aandeel } \\
Maatschappelijk/ & Kinder-/gezins- \\
Maltureel werkers & \multicolumn{2}{c}{ bej.verzorgenden } \\
culver & rij & kolom r rij \\
kolom & rij & $\%$ & $\%$ \\
$\%$ & $\%$ & $\%$
\end{tabular}

\section{Branches}

\section{Zorg en welzijnssector:}

Bejaardentehuizen

Kinder-/sociale tehuizen niet-gehandic.

Tehuizen/dagverblijven gehandicapten

Sociaal-med./-psychol./pedag. diensten

Maatschappelijke organisaties

Gezinsverzorging en gezinshulp

Kinderdagverblijven, crèches

Buurt- en clubhuis- en opbouwwerk

Jeugd-/jongerenwerk

Overige branches:

\begin{tabular}{rrrr}
$5 \%$ & & $21 \%$ & $31 \%$ \\
$6 \%$ & $4 \%$ & $3 \%$ & - \\
$5 \%$ & $28 \%$ & - & $\times$ \\
$5 \%$ & $10 \%$ & $x$ & - \\
$16 \%$ & $20 \%$ & - & $71 \%$ \\
$7 \%$ & $45 \%$ & $38 \%$ & $81 \%$ \\
- & $8 \%$ & $15 \%$ & - \\
$8 \%$ & - & - & $\times$ \\
- & $37 \%$ & & $0 \%$ \\
$46 \%$ & & & \\
\hline $100 \%$ & $1 \%$ & & $2 \%$ \\
\hline
\end{tabular}

Kolomtotaal

Rijtotaal

-: te weinig waarnemingen voor presentatie getal

$x$ : geen waarnemingen in betreffende categorie;

$0 \%$ : wel waarnemingen in categorie, echter afgerond $0 \%$

Bron: CBS/CPB/ROA

De verpleegkundigen en ziekenverzorgenden (inclusief zwakzinnigenverzorgenden) werken slechts voor een klein deel in de op deze wijze afgebakende sector ${ }^{7}$ (zie verder bijlagen 3 en 4).

Tabel $3.1 \mathrm{~b}$ geeft voor de totale beroepsbevolking aan in welke specifieke subsectoren van de zorg- en welzijnssector de maatschappelijk en cultureel werkers

7. Wanneer ook de zwakzinnigeninrichtingen en de verpleeghuizen tot de sector gerekend zouden worden werkt ruim tweederde van de leerling-verpleegkundigen en ziekenzwakzinnigen- en kraamverzorgenden in de zorg- en welzijnssector. 
en de kinder-, gezins- en bejaardenverzorgenden werkzaam zijn (zie kolompercentage), en omgekeerd welk aandeel de maatschappelijk werkers en verzorgenden binnen deze specifieke subsectoren in de zorg-en welzijnssector hebben (zie rijpercentage).

Van de kinder-/gezins- en bejaardenverzorgenden is weliswaar een belangrijk deel in de zorg- en welzijnssector werkzaam, doch het merendeel werkt hier in de verzorgende domeinen, zoals die in de bejaardenzorg en de gezinszorg opgeld doen. Slechts een klein deel van de kinder- en gezinsverzorgenden is werkzaam in subsectoren waar (veel) sociaal-pedagogisch werk voorkomt. Van de maatschappelijk werkers die in de zorg- en welzijnssector werkzaam zijn, werkt het merendeel in subsectoren die kenmerkend zijn voor het sociaal-pedagogisch werk.

Deze relatie ziet men ook in omgekeerde zin terug. De instellingen die zijn gericht op verzorgende taken voor - van oudsher - algemene (niet specifiekproblematische) doelgroepen bieden met name werk voor kinder-, gezins- en bejaardenverzorgenden. Instellingen die sociaal-pedagogische dan wel verzorgende taken hebben ten aanzien van cliënten met een (enkelvoudige of meervoudige) handicap, of sociaal-medische of sociaal-psychologische problemen recruteren hiervoor vaker maatschappelijk en cultureel werkers. Dit laatste geldt ook voor het buurt- en clubhuis- en opbouwwerk (en jeugd- en jongerenwerk).

Tabel $3.1 \mathrm{c}$

Aantal werkenden in werkzame beroepsbevolking, per beroepsklasse (aantal: gemiddelde 1993-1994, trend: ontwikkeling 1990-1994) en per opleidingstype (aantal: gemiddelde 19931994, trend: ontwikkeling 1992-1994)

\begin{tabular}{lrc}
\hline Beroepsbevolking naar beroep en opleiding & $\begin{array}{r}\text { Aantal } \\
\text { werkenden }\end{array}$ & Trend \\
\hline Totaal beroepsbevolking & 5.885 .500 & \\
Naar beroep & & \\
Maatschappelijk en cultureel werkers & 68.000 & stijgend \\
Naar opleiding & & \\
Totaal MBO & 2.285 .500 & stijgend \\
MBO sociaal-cultureel & 52.500 & constant \\
MBO verzorgend & 212.500 & constant \\
Totaal HBO & 1.022 .000 & 118.000 \\
HBO sociaal-cultureel & & \\
\hline Bron: CBS/ROA & &
\end{tabular}

Aangezien het platform met name in de arbeidmarktsituatie van de beroepsbeoefenaren in het sociaal-pedagogisch werk is geïnteresseerd, zal bij de beschrijving van de arbeidsmarkt-ontwikkelingen naar beroepsklasse alleen de situatie voor 
de beroepsklasse van de maatschappelijk en cultureel werkers worden aangegeven.

In Nederland zijn er gemiddeld over de jaren 1993 en 199468.000 beroepsbeoefenaren als maatschappelijk of cultureel werker werkzaam. Dit betekent dat $1,15 \%$ van de totale werkende beroepsbevolking van bijna 6 miljoen personen een beroep als maatschappelijk of cultureel werker vervult. Deze beroepsklasse kan daarmee middelgroot worden genoemd: circa driekwart van de ruim 90 onderscheiden beroepsklassen zijn wat betreft omvang kleiner dan de klasse van maatschappelijk en cultureel werkers. Gegevens uit de Enquête Beroepsbevolking (EBB) laten verder zien dat het aantal maatschappelijk en cultureel werkers de afgelopen jaren (1990-1994) is gestegen en dat het belang van de groep maatschappelijk en cultureel werkers in de werkgelegenheid eveneens is toegenomen (zie tabel 3.1c).

De resultaten van de EBB tonen aan dat gemiddeld in 1993 en 1994383.000 werkenden een sociaal-culturele (170.500) of verzorgende (212.500) opleidingsachtergrond hebben: 265.000 op MBO-niveau en 118.000 op HBOniveau. Het gaat hier om de hoogste opleiding waarvoor de werkende het diploma heeft behaald. Deze groep vormt $6,5 \%$ van de totale werkende beroepsbevolking. Zowel bij de werkende MBO'ers als HBO'ers heeft bijna $12 \%$ een sociaal-culturele of verzorgende opleiding gehad. Met uitzondering van de relatief kleine en stijgende groep werkenden met een sociaal-culturele opleidingsachtergrond op MBO-niveau, blijkt het aantal met een verzorgende MBO-opleiding of een sociaal-culturele $\mathrm{HBO}$ opleiding de afgelopen jaren constant te zijn.

\subsubsection{Man-/vrouwverhouding}

In tegenstelling tot de totale beroepsbevolking, waarbij $63 \%$ uit mannen bestaat, vormen vrouwen bij de maatschappelijk en cultureel werkers met $67 \%$ de meerderheid. Gemeten naar de opleidingsachtergrond van de werkenden kan op MBO-niveau eenzelfde beeld worden geconstateerd. Terwijl van alle werkenden met een MBO-opleiding slechts $37 \%$ vrouw is, is bij degenen die een sociaal-culturele of verzorgende $\mathrm{MBO}$-opleiding hebben behaald respectievelijk $68 \%$ en $81 \%$ vrouw. Op HBO-niveau is de man-/vrouwverhouding minder scheef. Van alle werkenden met een HBO-diploma is $42 \%$ vrouw, terwijl van degenen die een sociaal-culturele HBOopleiding hebben afgerond $58 \%$ van het vrouwelijk geslacht is.

De vraag is in hoeverre deze man-/vrouwverdeling voor de beroepsbevolking zich heeft ontwikkeld. Uit de EBB blijkt dat het aandeel vrouwen tussen 1990 en 1994 niet alleen is is toegenomen in de totale beroepsbevolking, maar eveneens in de beroepsklasse van de maatschappelijk en cultureel werkers. De beroepssegregatie tussen beide sexen is toegenomen. Een vergelijkbare trend geldt ook voor de 
beroepsbeoefenaren met een sociaal-culturele opleidingsachtergrond op HBOniveau.

Figuur 3.2a

Aandeel mannen en vrouwen in werkzame beroepsbevolking, per beroepsklasse (aandeel: gemiddelde 1993-1994, trend: 1990-1994) en opleidingstype (aandeel: gemiddelde 1993-1994, trend: 1992-1994)

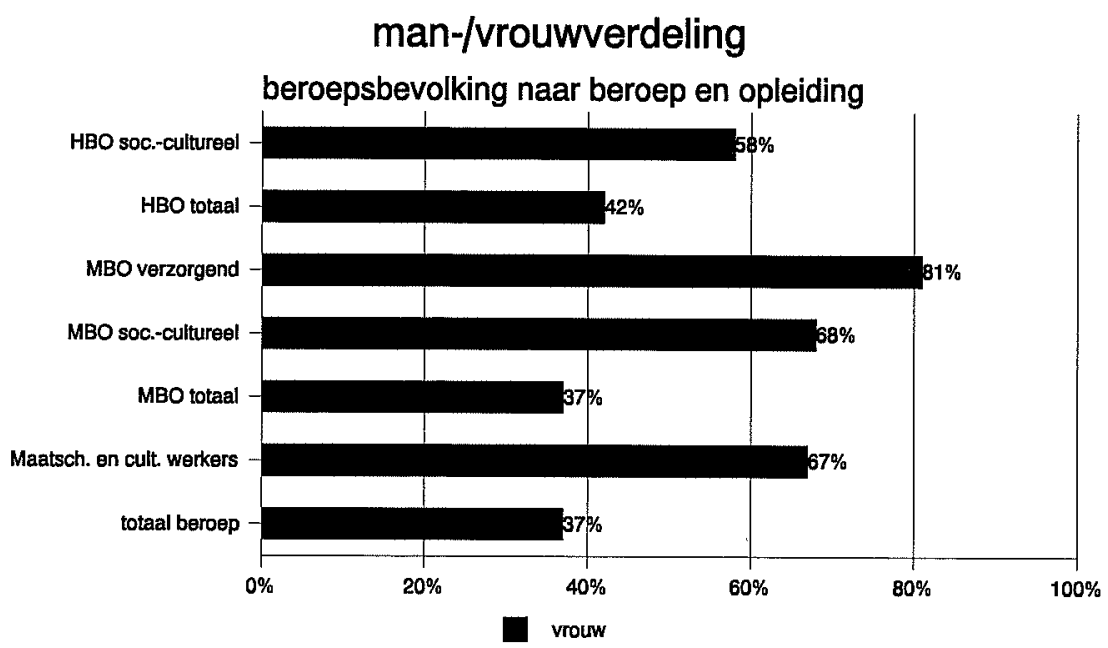

Bron: CBS/ROA

Verder is nagegaan in hoeverre de man-/vrouwverdeling voor de totale beroepsbevolking overeenkomt met deze verdeling onder schoolverlaters. De gegevens, ontleend aan de schoolverlatersonderzoeken RUBS en HBO-Monitor 1994, laten zien dat de (gediplomeerde) uitstroom uit de sociaal-culturele en verzorgende opleidingen op MBO- en HBO-niveau voornamelijk uit vrouwen bestaat. Met name op MBO-niveau is het aandeel mannen met percentages van $1 \%$ tot $17 \%$ extreem laag. Hoewel het aandeel vrouwen in de totale beroepsbevolking de laatste decennia snel is gestegen en vrouwen hun onderwijsachterstand ook ruimschoots hebben ingehaald, is de studiekeuze (en daarmee de beroepskeuze-mogelijkheden) nog steeds traditioneel.

In hoeverre de man-/vrouwverhouding voor de totale beroepsbevolking in de toekomst zal wijzigen, is de vraag. Immers, een deel van deze schoolverlaters zal, na al dan niet enige jaren gewerkt te hebben, in verband met gezinstaken geheel of gedeeltelijk uit het arbeidsproces verdwijnen. Tot op heden zijn het voornamelijk vrouwen die als gevolg van het hebben van kinderen de arbeidsmarkt (deels) verlaten. Dit verklaart tevens waarom het aandeel vrouwen met een sociaalculturele opleidingsachtergrond in de totale beroepsbevolking lager is dan onder de schoolverlaters. 
Figuur $3.2 b$

Aandeel mannen en vrouwen onder uitstroom MBO'ers en HBO'ers uit het studiejaar $1992 / 1993$

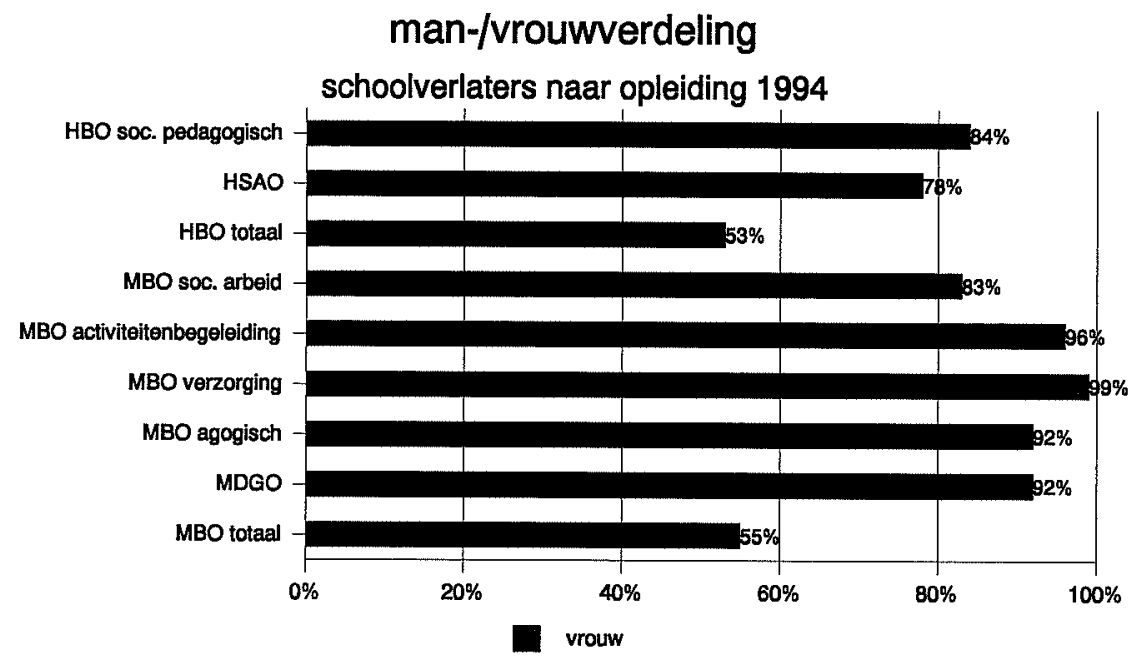

Bron: ROA (RUBS/HBO-Monitor)

\subsubsection{Full-time en part-time arbeid}

Dit brengt ons op de vraag of de maatschappelijk en cultureel werkers vaker in deeltijd werken dan de andere beroepsbeoefenaren. Dit blijkt inderdaad het geval te zijn. Van de maatschappelijk en cultureel werkers heeft $57 \%$ een deeltijdbaan (van maximaal 32 uur per week), terwijl onder de totale beroepsbevolking nog niet de helft daarvan, namelijk $25 \%$ in deeltijd werkzaam is. Gemeten naar de opleidingsachtergrond van de werkenden worden vergelijkbare cijfers aangetroffen. Van alle MBO'ers (44\%) en HBO'ers (42\%) met een sociaal-culturele opleidingsachtergrond werkt een relatief groot aandeel in een part-time functie.

Kan dit verschil in deeltijd-werk nu geheel worden toegeschreven aan het feit dat de in de beroepen en opleidingen van maatschappelijk en cultureel werkers de vrouwen zo sterk zijn oververtegenwoordigd? Het antwoord luidt: 'nee, slechts gedeeltelijk'. Hoewel mannen in alle sectoren vaker een full-time baan hebben dan vrouwen, zijn er wel degelijk verschillen tussen mannen (en vrouwen) uit verschillende beroepen-, bedrijfs- en opleidingssectoren. Zo hebben mannen met een hogere sociaal-agogische opleidingsachtergrond vaker een deeltijd-functie dan mannen met een andere HBO-opleiding. Vergelijkbare verschillen worden onder vrouwen aangetroffen. Ook daar hebben vrouwen met een economische of technische opleidingsachtergrond vaker een full-time functie in vergelijking met vrouwen met een sociaal-agogisch, verpleegkundig of paramedisch HBO-diploma. 
Figuur 3.3

Percentage in deeltijd en in voltijd werkenden in werkzame beroepsbevolking, per beroepsklasse (gemiddelde 1993-1994)

\section{deeltijdarbeid \\ beroepsbevolking naar beroep}
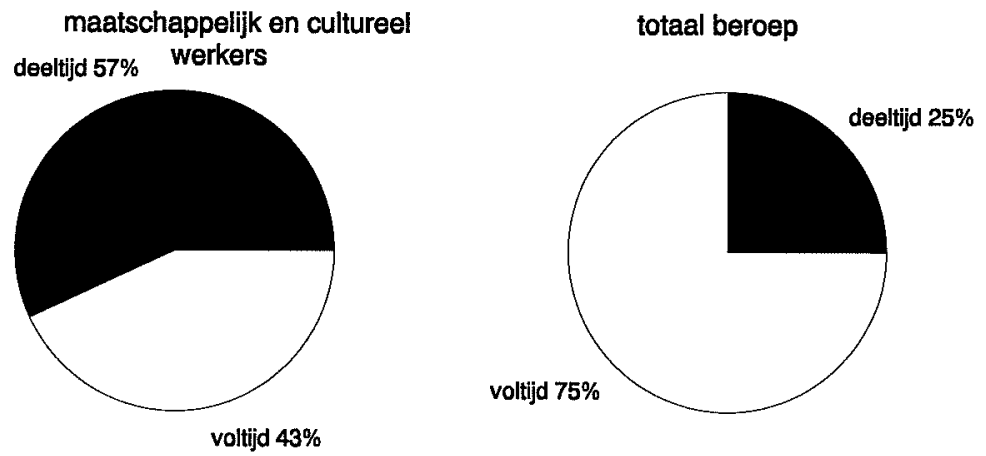

Bron: CBS/ROA

Het ligt voor de hand om aan te nemen dat een traditionele dan wel progressieve studiekeuze ook doorwerkt in keuzen in het arbeidsproces. Bovendien worden deze keuzen versterkt door de omgeving waarin deze keuzen worden gemaakt. Zowel tijdens de opleiding als in de functie en in de organisatie waarin men werkzaam is. Beeldvorming, over beide sexen en over het goed functioneren in bepaalde branches en beroepen, speelt hierbij een belangrijke en wederkerige rol.

\subsubsection{Leeftijdsopbouw}

Bijna driekwart van de maatschappelijk en cultureel werkers is tussen de 30 en 50 jaar oud. Ook in vergelijking met de leeftijdsopbouw in de totale beroepsbevolking is de groep van middelbare leeftijd in de beroepsklasse van maatschappelijk en cultureel werkers sterk oververtegenwoordigd. Jongeren (tussen de 15 en 30 jaar) en ouderen (tussen de 50 en 65 jaar) vormen tezamen slechts een ruime kwart van de groep maatschappelijk en cultureel werkers, terwijl zij $44 \%$ van de totale beroepsbevolking uitmaken. In vergelijking met de leeftijdsopbouw in de totale beroepsbevolking zijn de jongeren sterk ondervertegenwoordigd in deze beroepsklasse. Het lage aandeel jongeren heeft onder andere te maken met het relatief hoge gemiddelde opleidingsniveau van de beroepsbeoefenaren in deze beroepsklasse. Dit effect op de gemiddelde leeftijd wordt ook nog eens versterkt doordat een relatief groot aantal mensen pas op vrij late leeftijd aan een (hogere) sociaal-culturele (deeltijd)opleiding begint. 
Het lage aandeel ouderen kan verschillende oorzaken hebben, die met arbeidsmobiliteit samenhangen. Aan de ene kant kan er sprake zijn van beroepsmobiliteit naar andere beroepsklassen, waardoor de betreffende mensen niet meer in deze beroepscategorie zichtbaar zijn. Aan de andere kant wordt het lage aandeel van ouderen in deze beroepsklasse veroorzaakt door uitstroom uit het arbeidsproces als gevolg van arbeidsongeschiktheid en vrijwillige - vervroegde uittrede (bijv. VUT).

Figuur 3.4

Percentage werkenden in werkzame beroepsbevolking naar leeftijdsklasse, per beroepsklasse (gemiddelde 1993-1994)

\section{leeftijdsopbouw}

beroepsbevolking naar beroep
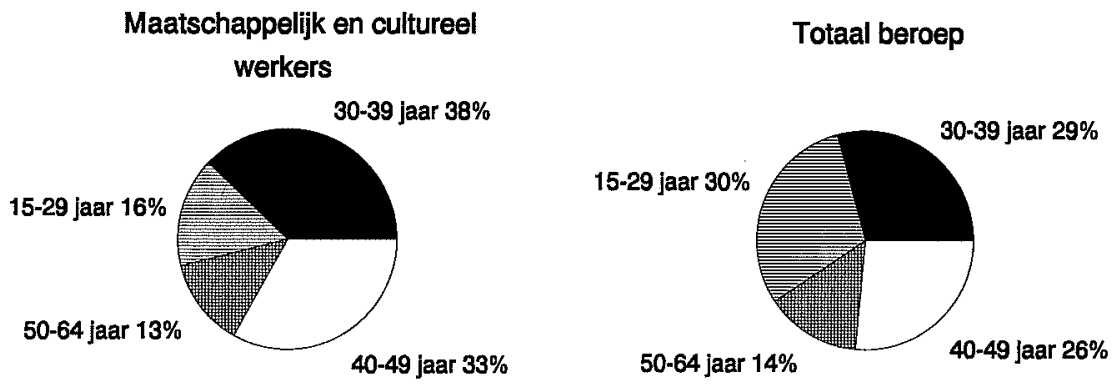

Bron: CBS/ROA

\subsubsection{Opleidingsachtergrond}

Ruim de helft (52\%) van de maatschappelijk en cultureel werkers heeft een opleiding op HBO-niveau genoten, $14 \%$ een universitaire opleiding en $27 \%$ heeft een MBO-diploma behaald. De overige $7 \%$ heeft ten hoogste een lagere beroepsopleiding (VBO) of algemeen voortgezette opleiding (MAVO, HAVO of WWO) afgerond. In vergelijking met de gehele beroepsbevolking is bij deze beroepsklasse sprake van een hoge en beroepsspecifieke opleidingsgraad: twee op de drie maatschappelijk werkers heeft hoger onderwijs genoten, tegenover nog geen kwart van de totale beroepsbevolking. Omgekeerd heeft bijna $37 \%$ van alle beroepsbeoefenaren hooguit lager (beroeps)onderwijs of algemeen voortgezet onderwijs gevolgd. Uit de EBB's over de voorafgaande jaren blijkt dat het aandeel MBO'ers in de beroepsklasse van de maatschappelijk en cultureel werkers de afgelopen jaren behoorlijk is toegenomen, ten koste van degenen die op HBO- of universitair niveau zijn geschoold. 
Figuur 3.5a

Percentage werkenden in werkzame beroepsbevolking naar opleidingsniveau, per beroepsklasse (gemiddelde 1993-1994)

\section{opleidingsachtergrond}

beroepsbevolking naar beroep

maatschappelijk en

cultureel werkers

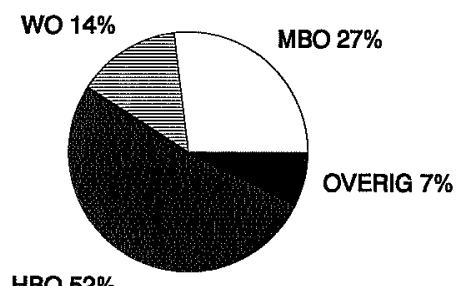

HBO 52\% totaal beroep

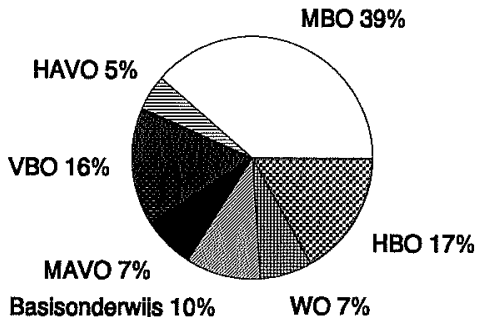

Bron: CBS/ROA

Tabel 3.5b

Belangrijkste opleidingstypen in beroepsklasse van maatschappelijk en cultureel werkers (aandeel: gemiddelde 1993-1994, trend: 1992-1994)

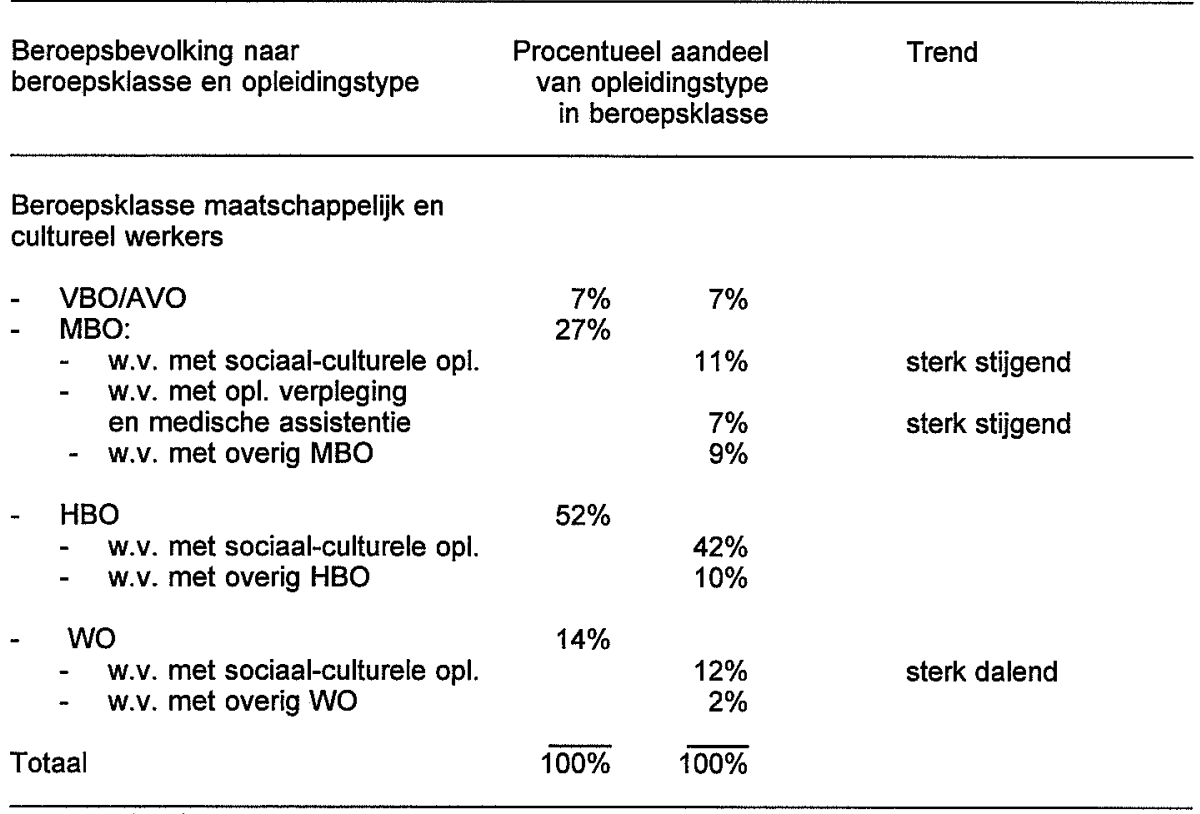

Bron: CBS/ROA 
Voor de beroepsklasse van maatschappelijk en cultureel werkers is niet alleen het niveau, maar tevens de genoten opleidingsrichting in kaart gebracht. Bijna twee op de drie $(65 \%)$ maatschappelijk en cultureel werkers heeft een sociaal-culturele opleidingsachtergrond, en $7 \%$ heeft een verplegende opleidingsrichting gevolgd. Uit tabel $3.5 \mathrm{~b}$ blijkt verder dat $21 \%$ van de maatschappelijk en cultureel werkers die een middelbare of hogere opleiding hebben genoten, een andere opleidingsrichting hebben genoten. Hoewel de sociaal-culturele opleidingen de belangrijkste zijn waaruit werkgevers hun kandidaten selecteren, blijken daarnaast ook anders geschoolden voor deze beroepsklasse te worden geworven. Op deze wijze kunnen werkgevers multidisciplinaire teams samenstellen, waarbij optimaal gebruik kan worden gemaakt van een breed scala aan deskundigheden.

\subsection{Knelpunten op de arbeidsmarkt}

\subsubsection{Het potentiële aanbod}

Gegevens over het aantal gediplomeerden van voor het werkveld relevante beroepsopleidingen zijn niet voldoende om de instroom in de sociaal-agogische beroepen in de zorg- en welzijnssector weer te geven. In de eerste plaats stroomt een deel van de gediplomeerden door naar het vervolgonderwijs. Een belangrijk deel hiervan kiest overigens wel een vervolgstudie in een vergelijkbare richting, zodat zij op een later tijdstip alsnog beschikbaar komen voor de arbeidsmarkt in de zorg- en welzijnssector. Echter wel gericht op een voor een deel ander beroependomein.

In de tweede plaats gaat een deel van de afgestudeerden naar een werkkring buiten de zorg- en welzijnssector en/of vervult naar de studie een niet sociaalagogisch beroep. Ten slotte zal een aantal gediplomeerden zich helemaal niet aanbieden op de arbeidsmarkt, hoewel (gedeeltelijke) uittrede als gevolg van gezinstaken vaak pas na enkele jaren plaatsvindt.

Tabel 3.6 geeft een beeld van de belangrijkste bezigheid op het moment van enquête van de gediplomeerden van de onderscheiden MBO- en HBO-opleidingen. Voor de MBO'ers betreft het de situatie circa één jaar na het behalen van het diploma, terwijl het bij de HBO'ers om de situatie na ongeveer anderhalf jaar na afstuderen gaat. In beide gevallen betreft het de afgestudeerden uit het studiejaar $1992 / 1993$.

Doorgaans is de helft tot tweederde van de afgestudeerden van de voor dit werkveld relevante MBO-opleidingen toegetreden tot de arbeidsmarkt. Slechts een klein percentage hiervan noemt zich op het moment van enquêteren werkzoekend. Toch komt maar één tot tweevijfde deel van de schoolverlaters direct terecht in een 
functie die zowel qua niveau als richting goed aansluit bij het eigen opleidingsniveau. Voor MBO sociale arbeid is dit slechts $12 \%$. Met uitzondering van MBO sociale arbeid, gaan bij de sociaal-agogische en verzorgende MBO- en HBOopleidingen veel schoolverlaters na de opleiding direct in het eigen werkveld werken. Er wordt echter wel geconstateerd dat een belangrijk deel weliswaar in de eigen richting werkzaam is, maar vaak niet op het eigen opleidingsniveau: er kan dan sprake zijn van onderbenutting van de kwalificaties van afgestudeerden.

Tabel 3.6

Bestemming van gediplomeerde schoolverlaters naar opleiding, 1994

\begin{tabular}{|c|c|c|c|c|c|c|c|}
\hline & \multicolumn{7}{|c|}{ Bestemming } \\
\hline & $\begin{array}{l}\text { Werk } \\
\text { eigen } \\
\text { domein }\end{array}$ & $\begin{array}{l}\text { Werk } \\
\text { eigen } \\
\text { richting }\end{array}$ & $\begin{array}{l}\text { Werk } \\
\text { overig }\end{array}$ & $\begin{array}{l}\text { Werk- } \\
\text { zoekend }\end{array}$ & Studie & Dienst & Anders \\
\hline \multicolumn{8}{|l|}{ Opleiding } \\
\hline $\begin{array}{l}\text { Totaal MBO } \\
\text { MDGO } \\
\text { MBO agogisch werk } \\
\text { MBO verzorging } \\
\text { MBO activiteiten- }\end{array}$ & $\begin{array}{l}19 \% \\
23 \% \\
24 \% \\
30 \%\end{array}$ & $\begin{array}{r}6 \% \\
13 \% \\
6 \% \\
27 \%\end{array}$ & $\begin{array}{l}23 \% \\
22 \% \\
22 \% \\
28 \%\end{array}$ & $\begin{array}{l}5 \% \\
4 \% \\
4 \% \\
3 \%\end{array}$ & $\begin{array}{l}39 \% \\
35 \% \\
41 \% \\
11 \%\end{array}$ & $\begin{array}{l}7 \% \\
3 \% \\
1 \% \\
0 \%\end{array}$ & $\begin{array}{l}1 \% \\
2 \% \\
3 \% \\
1 \%\end{array}$ \\
\hline $\begin{array}{l}\text { begeleiding } \\
\text { MBO sociale arbeid }\end{array}$ & $\begin{array}{l}38 \% \\
12 \%\end{array}$ & $\begin{array}{r}10 \% \\
1 \%\end{array}$ & $\begin{array}{l}18 \% \\
15 \%\end{array}$ & $\begin{array}{l}3 \% \\
9 \%\end{array}$ & $\begin{array}{l}27 \% \\
62 \%\end{array}$ & $\begin{array}{l}0 \% \\
1 \%\end{array}$ & $\begin{array}{l}2 \% \\
2 \%\end{array}$ \\
\hline $\begin{array}{l}\text { Totaal HBO } \\
\text { HSAO } \\
\text { HBO sociaal-pedagogisch }\end{array}$ & $\begin{array}{l}51 \% \\
48 \% \\
36 \%\end{array}$ & $\begin{array}{l}11 \% \\
30 \% \\
41 \%\end{array}$ & $\begin{array}{r}14 \% \\
5 \% \\
10 \%\end{array}$ & $\begin{array}{l}7 \% \\
5 \% \\
4 \%\end{array}$ & $\begin{array}{r}13 \% \\
7 \% \\
6 \%\end{array}$ & $\begin{array}{l}1 \% \\
0 \% \\
0 \%\end{array}$ & $\begin{array}{l}3 \% \\
2 \% \\
3 \%\end{array}$ \\
\hline
\end{tabular}

Bron: CBS/ROA

Tussen de gediplomeerden van de MBO-opleidingen bestaan grote verschillen in het percentage dat naar het vervolgonderwijs is gegaan. Het percentage dat na de studie heeft gekozen voor een vervolgopleiding loopt uiteen van $11 \%$ voor MBO verzorging tot $62 \%$ voor MBO sociale arbeid. Zoals gezegd komt een groot gedeelte van deze verder studerenden op een later momemt op de arbeidsmarkt voor de sociaal-agogen, vaak wel met de bedoeling een functie op een hoger niveau te verwerven.

$\mathrm{Bij}$ het $\mathrm{HBO}$ is het percentage dat verder gaat studeren met $13 \%$ fors lager, zeker bij het HSAO (inclusief sociaal-pedagogische hulpverlening). Bijna alle afgestudeerden van het $\mathrm{HBO}$ bieden zich na de opleiding aan op de arbeidsmarkt, waarvan slechts een klein gedeelte op het moment van enquêteren werkzoekend is. Van de afgestudeerden van het HBO komt wel een groter gedeelte terecht in het eigen beroependomein dan van de schoolverlaters van het $\mathrm{MBO}$, al is dit percentage bij het HSAO in het algemeen en bij sociaal-pedagogische hulpverlening in het 
bijzonder minder het geval. Weliswaar werken de meeste HSAO'ers en SPH'ers in een functie die aansluit bij de eigen richting, maar een relatief groot percentage is werkzaam in een functie onder HBO-niveau. Met name binnen het werkveld van de sociaal-pedagogische hulpverlening zijn er functies waarvoor zowel sociaal-agogen op MBO- en HBO-niveau worden aangenomen (zoals bijvoorbeeld bij de groepsleiders). De op HBO-niveau geschoolden lopen in dergelijke functies snel het risico in hun kwalificaties te worden onderbenut.

De vraag bij deze resultaten is uiteraard of deze voortvloeien uit de eigen keuze die de afgestudeerden na de opleiding hebben gemaakt, of dat deze worden veroorzaakt door de arbeidsmarktpositie van de afgestudeerden in het eigen beroependomein. Met andere woorden in hoeverre zijn de resultaten aanbod- of vraagbepaald. Uit nadere analyses van de schoolverlatersonderzoeken van de afgelopen jaren blijkt dat de schoolverlaters in tijden van economische recessie vaker kiezen voor een vervolgstudie (of het dan al vervullen van de dienstplicht) of gedwongen worden een baan onder het eigen niveau te accepteren. Op het moment dat de werkgelegenheid in het eigen beroependomein weer toeneemt, kiezen de schoolverlaters weer vaker voor het dan al toetreden tot de arbeidsmarkt. Op zo'n moment is het natuurlijk voor de werkgevers van belang dat zij de vacatures in hun sector opnieuw gemakkelijk kunnen vervullen.

\subsubsection{Vacatures}

Knelpunten in de personeelsvoorziening kunnen onder andere aan de hand van het percentage moeilijk vervulbare vacatures worden afgemeten. Tabel 3.7 geeft een overzicht van het percentage moeilijk vervulbare vacatures in het totaal aantal vacatures $^{8}$ voor de beroepsklasse van maatschappelijk en cultureel werkers (Centraal Bureau voor de Statistiek, Vacature-enquête september 1994). De beoordeling of een vacature moeilijk vervulbaar is heeft het CBS aan de responderende organisaties zelf overgelaten. In het algemeen blijkt één op de vijf vacatures in Nederland moeilijk vervulbaar te zijn, terwijl dit bij de maatschappelijk en cultureel werkers voor circa één op de tien vacatures geldt. De personeelsvoorziening voor de maatschappelijk en cultureel werkers was daarmee medio 1994 minder moeizaam dan gemiddeld voor de andere vacatures het geval was.

Ongeveer één op de vier à vijf vacatures voor maatschappelijk en cultureel werkers betrof een baan voor een schoolverlater. Dit aandeel in het totaal aantal vacatures

8. Exclusief vacatures bij overheid, onderwijs, sociale werkplaatsen, uitzendbureaus en uitleenbedrijven. 
voor deze beroepsklasse is lager dan voor de totale beroepsbevolking geldt. Bovendien had in 1994 twee op de drie vacatures betrekking op een full-time of grote deeltijdbaan. De vacatures voor maatschappelijk en cultureel werkers betroffen naar verhouding vaker (kleine) deeltijdbanen.

Tabel 3.7

Vacatures in Nederland, naar beroepsklasse, september 1994 (afgerond op 100-tallen)

\begin{tabular}{lcc}
\hline & $\begin{array}{c}\text { Maatschappelijk \& } \\
\text { cultureel werkers } \\
\text { absoluut }\end{array}$ & $\begin{array}{l}\text { Totaal } \\
\text { beroeps- } \\
\text { bevolking } \\
\text { absoluut }\end{array}$ \\
\hline Totaal aantal vacatures & 900 & 39.400 \\
w.v. voor schoolverlaters & 200 & 11.800 \\
W.v. voor minimaal 20 uur per week & 600 & 30.600 \\
w.v. moeilijk vervulbaar & 100 & 7.900 \\
\hline
\end{tabular}

Bron: CBS (Vacature-enquête 1994)

\subsubsection{Werkloosheid}

\section{Werkzoeken tijdens intredeperiode}

Werkloosheid tijdens de arbeidsmarktintrede geeft een indicatie voor de mate waarin de intrede op de arbeidsmarkt minder succesvol verloopt. Het gaat hier om schoolverlaters die gedurende de periode dat zij zich hebben aangeboden op de arbeidsmarkt op zoek zijn geweest naar een betaalde werkkring. De schoolverlaters van zowel het MDGO als het MBO totaal die zich hebben aangeboden op de arbeidsmarkt, zijn in ongeveer $15 \%$ van de gevallen meer dan drie maanden werkzoekend geweest gedurende de intredeperiode. Bij de MBO-richtingen agogisch werk en sociale arbeid gaat het zelfs om $21 \%$ van de intreders op de arbeidsmarkt. Op HBO-niveau blijkt het percentage afgestudeerden dat gedurende de intredeperiode voor meer dan drie maanden op zoek is geweest naar betaald werk voor zowel het gehele hoger sociaal-agogisch onderwijs als sociaalpedagogische hulpverlening lager dan gemiddeld voor het totale HBO geldt.

\section{Werkloosheid op enquêtemoment}

Momenteel zijn er in Nederland nog geen (betrouwbare) werkloosheidscijfers naar beroepsklasse voorhanden. Wel is de werkloosheid onder de schoolverlaters, conform de CBS-definitie van geregistreerde werkloosheid, gemeten. Onder de schoolverlaters van de MDGO-opleiding sociale arbeid is het werkloosheidspercentage relatief hoog, namelijk $19 \%$. Bij de andere sociaal-culturele MBOopleidingen varieert het werkloosheidspercentage van $5 \%$ tot $8 \%$, hetgeen 
vergelijkbaar is met het gemiddelde van $7 \%$ voor het totale MBO. Onder de afgestudeerden van het hoger sociaal-agogisch, waaronder het sociaal-pedagogisch onderwijs, is het percentage werklozen met zo'n $5 \%$ beduidend lager dan onder alle HBO'ers tezamen.

Figuur 3.8

Percentage langdurige werkzoekenden tijdens intredeperiode en werklozen op enquêtemoment onder uitstroom MBO'ers en HBO'ers uit het studiejaar 1992/1993

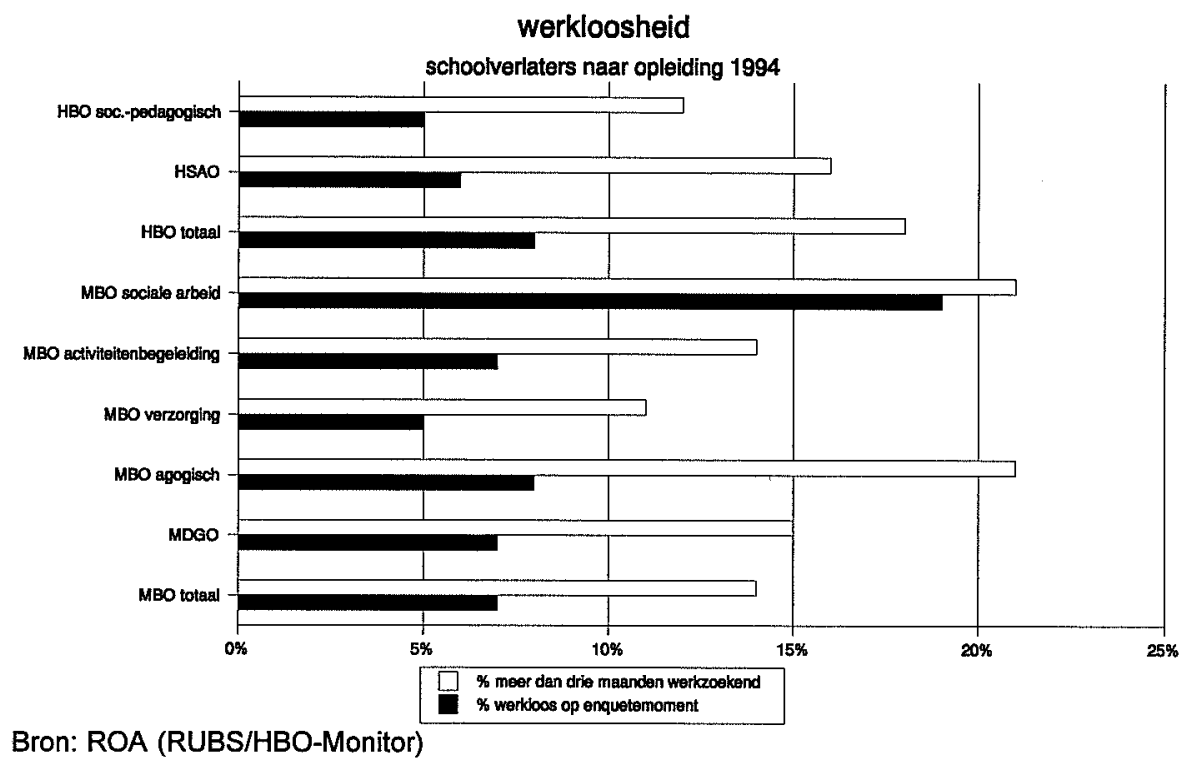

Bij het interpreteren van de resultaten van zowel de duur van de 'intredewerkloosheid' als het werkloosheidspercentage ten tijde van de meting, dient men zich te realiseren dat een gemiddeld relatief korte duur van de intredewerkloosheid niet altijd gepaard hoeft te gaan met een laag werkloosheidspercentage op het moment van enquêteren. Wanneer een schoolverlater relatief snel betaald werk vind, is dat immers nog geen garantie dat deze een jaar later nog steeds dit of ander werk heeft.

\subsubsection{Risico-indicatoren: conjunctuurgevoeligheid \& uitwijkmogelijkheden}

\section{Conjunctuurgevoeligheid}

Discrepanties tussen vraag en aanbod op de arbeidsmarkt kunnen voortkomen uit structurele veranderingen in de vraagontwikkeling maar er kan ook sprake zijn van tijdelijke aanpassingsproblemen vanwege conjuncturele schommelingen. In deze paragraaf wordt kort ingegaan op de conjunctuurgevoeligheid van de 
werkgelegenheid voor de sociaal-agogische beroepen in de sector zorg en welzijn en de opleidingen die voor deze sociaal-agogische beroepen opleiden.

Tabel 3.9

Conjunctuurgevoeligheid, per beroepsklasse en opleidingstype in de beroepsbevolking

\begin{tabular}{|c|c|c|}
\hline \multirow{2}{*}{$\begin{array}{l}\text { Beroepsbevolking } \\
\text { naar beroep en opleiding }\end{array}$} & \multicolumn{2}{|c|}{ Conjunctuurgevoeligheid } \\
\hline & index & typering \\
\hline \multicolumn{3}{|l|}{ Naar beroep } \\
\hline Maatschappelijk en cultureel werkers & 0,36 & laag \\
\hline \multicolumn{3}{|l|}{ Naar opleiding } \\
\hline MBO sociaal-cultureel & 0,51 & laag \\
\hline MBO verzorgend & 0,51 & laag \\
\hline HBO sociaal-cultureel & 0,49 & laag \\
\hline
\end{tabular}

Bron: CBS/ROA

Een hoge conjunctuurgevoeligheid vormt immers terdege een risicofactor voor schoolverlaters met een bepaalde opleidingsachtergrond, en vormt daarmee een keuze-element in de beslissing ten aanzien van de opleiding.

De sociaal-culturele beroepen en opleidingen blijken een lage conjunctuurgevoeligheid te hebben. (Het zijn met name technische beroepen en opleidingen die bijzonder conjunctuurgevoelig zijn.)

Op zichzelf is het gunstig dat de werkgelegenheidsontwikkeling in de sociaalculturele sector stabiel is. De arbeidsmarktsituatie kan echter door een eventuele plotselinge trendbreuk, als gevolg van bijvoorbeeld een sterke overheidsbezuiniging, wel ineens fors wijzigen. Wanneer er dan niet voldoende uitwijkmogelijkheden op de arbeidsmarkt zijn voor deze schoolverlaters, zal een sterke verandering in de werkgelegenheidsontwikkeling hard aankomen.

\section{Uitwijkmogelijkheden}

Deze paragraaf wordt daarom vervolgd met een korte uiteenzetting over eventuele uitwijkmogelijkheden op de arbeidsmarkt voor beroepsbeoefenaren met een sociaalculturele functie of opleidingsachtergrond. Het gaat hier om mogelijke substitutieprocessen als gevolg van vraag- en aanboddiscrepanties op de arbeidsmarkt. Vanuit de aanbodzijde bezien hebben de uitwijkmogelijkheden betrekking op de breedte van het beroependomein waarin men na de studie terecht kan komen. Vanuit de werkgever, de vraagzijde, bezien gaat het om de flexibiliteit om voor een specifiek beroep mensen met een verschillende opleidingsachtergrond 
te werven. Net zoals het voor aanbieders van arbeid gunstig is om niet afhankelijk te zijn van de vraag naar arbeid in een specifieke bedrijfsklasse of beroepsgroep, is het voor werkgevers in principe ook aantrekkelijk om bij de personeelswerving voor een bepaald beroep niet afhankelijk te zijn van het arbeidsaanbod met slechts één of enkele soort opleidingsachtergrond. In geval van aanbodtekorten bij de ene opleiding kan men dan immers zonder veel extra scholingsinspanningen personeel werven met een andere opleidingsachtergrond.

Figuur 3.10a

Uitwijkmogelijkheden naar bedrijfsklassen, per beroepsklasse en opleidingstype in de beroepsbevolking

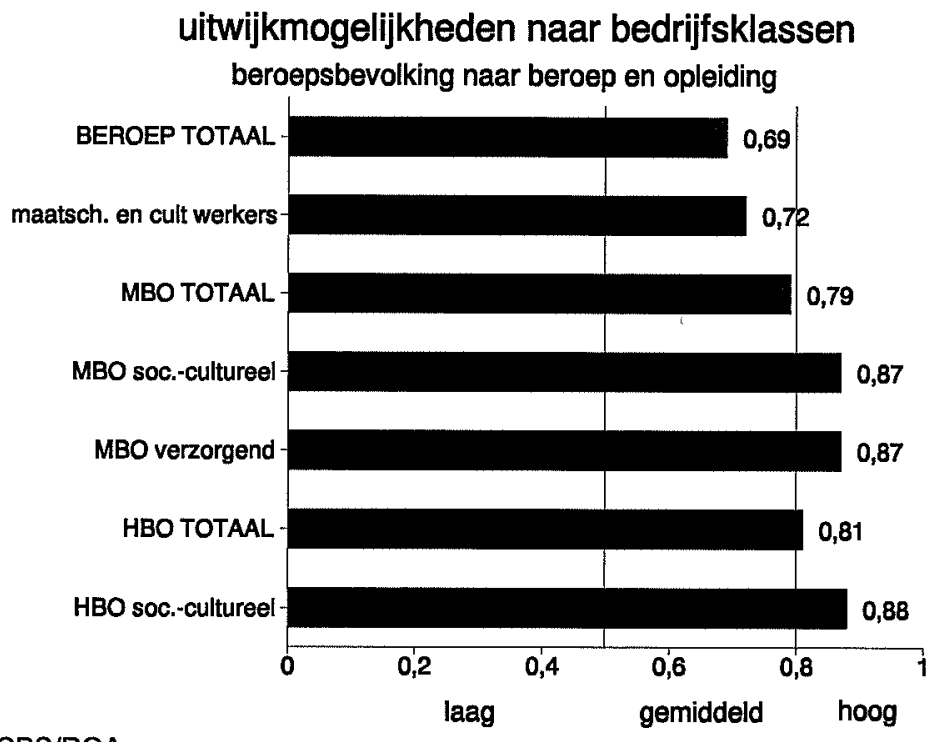

Bron: CBS/ROA

In figuur 3.10a worden de uitwijkmogelijkheden naar diverse bedrijfsklassen in beeld gebracht, terwijl figuur 3.10b de uitwijkmogelijkheden naar diverse beroepsgroepen belicht, voor zover het om uitwijkmogelijkheden gaat naar beroepen op een aansluitend of hoger functieniveau. De uitwijkmogelijkheden worden gemeten met de zogenaamde Gini-Hirschman-indicator.

Deze indicator, die is gebaseerd op de kans dat twee personen met eenzelfde opleidingsachtergrond in eenzelfde bedrijfsklasse of beroepsgroep werkzaam zijn, is minimaal 0 als de beroepsbeoefenaren met die opleidingsachtergrond inderdaad slechts in één bedrijfsklasse of beroepsgroep werkzaam zijn, en komt steeds dichter bij de waarde 1 naarmate de werkgelegenheid sterker is gespreid. 
Uit figuur 3.10a blijkt dat in vergelijking met andere beroepsklassen en opleidingstypen de maatschappelijk en cultureel werkers en de beroepsbeoefenaren met een sociaal-culturele of verzorgende opleidingsachtergrond veel uitwijkmogelijkheden naar diverse branches hebben. Ook de uitwijkmogelijkheden naar beroepsgroepen op een aansluitend of hoger functieniveau blijken voor hen gemiddeld genoemd te kunnen worden.

Figuur $3.10 b$

Uitwijkmogelijkheden naar beroepsklassen op aansluitend of hoger niveau, per beroepsklasse en opleidingstype in de beroepsbevolking

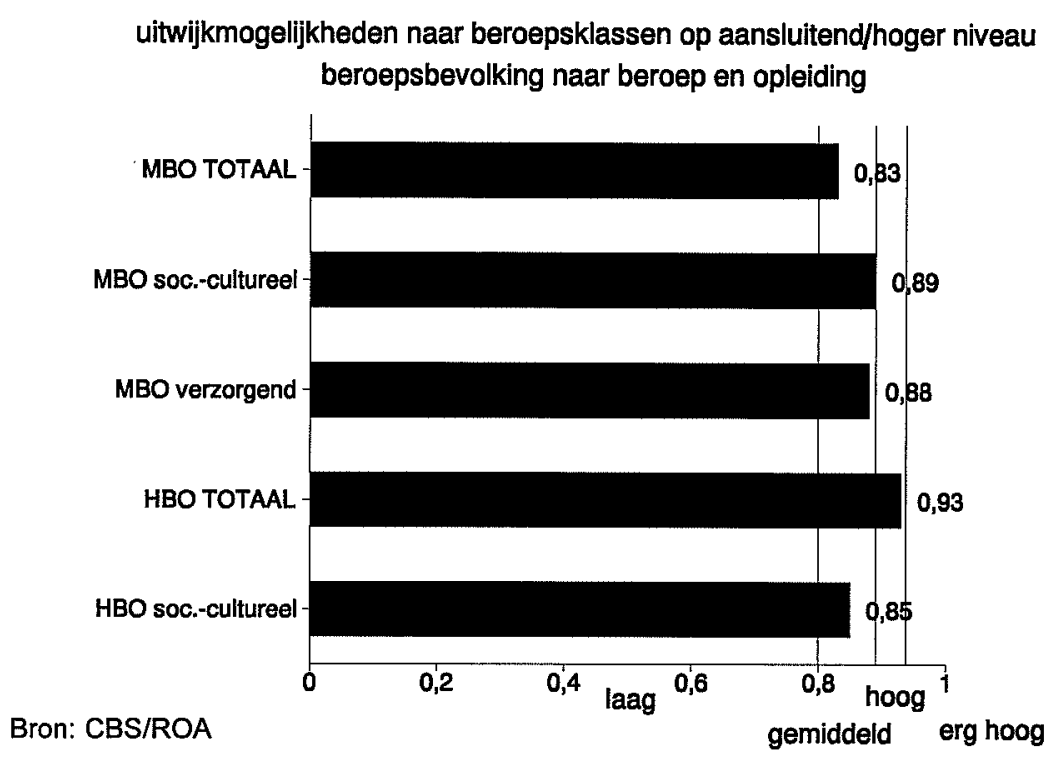

Deels zijn de gevonden resultaten echter het gevolg van de nogal diverse samenstelling van de onderscheiden sociaal-culturele beroepsklasse en opleidingstypen. Wanneer namelijk voor de schoolverlaters de uitwijkmogelijkheden op het niveau van de afzonderlijke studierichtingen in het MDGO of het HSAO in ogenschouw wordt genomen, dan blijken zij relatief weinig uitwijkmogelijkheden te hebben. Dit geldt overigens in sterkere mate voor de afgestudeerden van het HSAO dan voor het MDGO, en binnen het $H S A O$ zijn er vooral weining uitwijkmogelijkheden voor de afgestudeerden van sociaal-pedagogische hulpverlening, maatschappelijk werk en creatieve therapie.

Daarnaast kan het geconstateerde verschil in uitwijkmogelijkheden tussen de schoolverlaters en de totale beroepsbevolking een gevolg zijn van het feit dat aan het begin van de beroepsloopbaan minder uitwijkmogelijkheden voor de sociaal- 
agogisch geschoolden aanwezig zijn, terwijl er na verloop van tijd meerdere keuzemogelijkheden voor de afgestudeerden van deze opleidingen ontstaan.

\subsubsection{Concurrentie in arbeidsmarktsegmenten zorg- en welzijnssector}

De afgelopen jaren is de discussie op gang gekomen over de (kern)kwalificaties en opleidingsprofielen van beroepopleidingen, in het licht van de beroepsprofielen van deze opleidingen. Ook het Platform Kwalificatiebeleid Zorg en Welzijn heeft haar werkzaamheden op dit vraagstuk gericht. In het verlengde van deze discussie wordt momenteel eveneens de herstructurering van het hoger (beroeps)onderwijs aan de orde gesteld. In navolging van de aanbevelingen van de Commissie Brouwer, is nagegaan in hoeverre de (sociaal-agogische) beroepsopleidingen concurrerende dan wel complementaire beroependomeinen hebben.

De beroependomeinen van opleidingstypen kunnen een overlap vertonen. De concurrentie-index geeft aan hoe sterk de beroepenstructuur van verschillende opleidingen met elkaar overeenkomen (zie figuur 3.11). Bij een volledige overeenkomst van het beroependomein is deze index 1 , terwijl de concurrentieindex 0 is als er geen enkele beroepsgroep is waarin beide opleidingstypen voorkomen (Borghans, 1992).

Bij de discussie over het concurrerende dan wel complementaire karakter van de (beroepen)domeinen van de opleidingen, speelt de belangenafweging tussen 'brede' algemeen en 'smalle' specialistisch georiënteerde opleidingen een belangrijke rol. Om een zo goed mogelijke aansluiting tussen onderwijs en arbeidsmarkt te realiseren dient een afweging gemaakt te worden tussen specialisme en flexibiliteit. Door een (initiële) opleiding erg toe te spitsen op een specifiek beroep zijn de afgestudeerden optimaal voorbereid op de uitoefening van dit beroep en zal de produktiviteit meteen al erg hoog kunnen zijn. Wanneer bovendien slechts enkele opleidingen voor dit beroep opleiden is de concurrentie vanuit andere opleidingen in dit segment gering.

Opleidingen zijn in een dergelijke situatie complementair. Een nadeel van een specialistische invulling van het onderwijs is echter dat de betreffende afgestudeerden sterk afhankelijk zijn van de werkgelegenheids-ontwikkeling in dit specifieke beroep, waardoor zij bijzonder gevoelig zijn voor zogenaamde 'varkenscycli' op de arbeidsmarkt. Om flexibiliteit op de arbeidsmarkt en in de latere loopbaan te waarborgen is het daarom zinvol studenten breder op te leiden. Wanneer meerdere opleidingen voor dit bredere segment opleiden, is de concurrentie op dit segment wel groter. Tussen deze drie krachten, produktiviteit, flexibiliteit en concurrentie, dient een afweging gemaakt te worden. Hoe deze uitvalt 
is mede afhankelijk van de marktpositie van de beroepsbeoefenaren met een bepaalde opleidingsachtergrond.

Tabel 3.11

Overzicht van opleidingstypen waarvan op de arbeidsmarkt (sterke) concurrentie wordt ondervonden (totale beroepsbevolking)

Opleidingstype concurrentie index

\section{MBO sociaal-cultureel}

- HBO sociaal-cultureel

- MBO/LLW verzorging

- HAVONWO bovenbouw

rentie index

- MAVO, onderbouw HAVONWO

- MBO/LLW verpleging en medisch

- WO sociaal-cultureel

- VBO verzorging

MBO/LLW verzorging

- MBO sociaal-cultureel

- VBO verzorging

- MAVO, onderbouw HAVONWO

- VBO textiel- en ledertechniek

0,41

- MBO/LLW horeca en uiterlijke verzorging $\quad 0,38$

- HAVO/MWO bovenbouw

- MBO/LLW verpleging en medische assistentie

- Basisonderwijs

HBO sociaal-cultureel

- MBO sociaal-cultureel

- WO sociaal-cultureel

Bron: ROA

Uit tabel 3.11 blijkt dat de concurrentie in de arbeidsmarktsegmenten voor de beroepsbeoefenaren met een sociaal-agogische of verzorgende opleidingsachtergrond zich zowel naar opleidingsniveau als opleidingsrichting manifesteert. Het gaat dan doorgaans om een verwante opleidingsrichting, dan wel een naastliggend opleidingsniveau. Verder kan men constateren dat concurrentie bij de voor de verzorging opgeleide beroepsbeoefenaren meer tussen het lager en middelbaar niveau plaatsvindt, terwijl er bij het sociaal-cultureel segment meer concurrentie plaats heeft tussen de middelbaar en hoger opgeleiden.

Vervolgens komt dan uiteraard de vraag naar voren in welke segmenten de beroepsbeoefenaren en schoolverlaters nu eigenlijk terechtkomen (en in welke segmenten bovenstaande concurrentie zich dan manifesteert). Tabel $3.12 a$ toont voor de totale beroepsbevolking, onderscheiden naar opleidingtype, in welke beroepsklassen de beroepsbeoefenaren met een bepaalde opleidingsachtergrond werkzaam zijn. Daarnaaast wordt in Tabel 3.12a ook de trend aangegeven: daalt of stijgt het aandeel van een bepaalde beroepsklasse in de totale werkgelegenheid 
van beroepsbeoefenaren met een verzorgende of sociaal-culturele beroepsopleiding? Hoewel er in enige mate overlap geconstateerd wordt tussen de diverse opleidingen wat betreft het beroependomein, blijken de onderscheiden opleidingen zich ieder wel op een bepaald deel van de arbeidsmarkt te richten.

In sommige arbeidsmarktsegmenten is de concurrentie tussen de opleidingen overigens wel sterker dan in andere delen van de arbeidsmarkt. Zowel bij het MBO sociaal-cultureel als het $\mathrm{HBO}$ sociaal-cultureel is een relatief groot percentage werkzaam in de beroepsklasse van maatschappelijk werkers. Op het MBO-niveau gaat het met name om concurrentie op het vlak van de verzorgende functies.

Tabel 3.12a

Belangrijkste beroepsklassen in de totale beroepsbevolking per opleidingstype (minimum aandeel 5\%; gemiddelde 1993-1994; trend 1992-1994)

Aandeel beroepsklasse Trend

Beroepsklassen per opleidingstype

MBO sociaal-cultureel

- maatschappelijk werkers

- kinder-, gezins- en bejaardenverzorgenden

- leerling-verpleegkundigen,

zieken- en kraamverzorgenden

- expeditie- en administratief personeel

- bibliotheek en archiefmedewerkers

- overige beroepsklassen

Totaal

\section{MBO verzorging}

- kinder-, gezins- en bejaardenverzorgenden

- leerling-verpleegkundigen,

zieken- en kraamverzorgenden

- keuken- en serveerpersoneel

- kappers en schoonheidsspecialisten

- verkooppersoneel

- overige beroepsklassen

Totaal

HBO sociaal-cultureel

- maatschappelijk werkers

- arbeidsconsulenten en personeeisdeskundigen

- bibliothecarissen en archivarissen

- hogere leidinggevenden financiën, verkoop e.d.

- overige beroepsklassen

Totaal
$14 \%$

$13 \%$

$12 \%$

$9 \%$

$5 \%$

$47 \%$

$\overline{100 \%}$

stijgend

sterk stijgend

dalend

stijgend

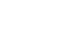

stijgend

stijgend

stijgend

sterk dalend

$5 \%$

$40 \%$

$\overline{100 \%}$

$24 \%$

$10 \%$

$7 \%$

$6 \%$

$53 \%$

$\overline{100 \%}$ constant sterk stijgend

-: te weinig waarnemingen voor presentatie trend Bron: CBS/ROA 
Tabel 3.12b

Belangrijkste branches werkende schoolverlaters, per opleiding, 1994 (minimum aandeel 5\%)

Branches MBO agogisch ${ }^{a}$

- kinderdagverblijven/crèches (gezonde kinderen)

- tehuizen voor geestelijk/dubbel gehandicapten

- overige branches

Branches MBO verzorging ${ }^{a}$

- bejaardentehuizen (geen psychogeriatrie) $24 \%$

- gezinsverzorging/bejaardenhulpinstellingen $14 \%$

- verpleeghuizen (psychisch) $12 \%$

- kraamcentra (geen klinieken, extramuraal) $11 \%$

- verpleeghuizen (somatisch) $\quad 11 \%$

- algemene ziekenhuizen (niet academisch) $\quad 8 \%$

$\begin{array}{ll}\text { - overige branches } & 20 \%\end{array}$

$\begin{array}{ll}\text { Totaal } & \overline{100 \%}\end{array}$

Branches MBO activiteitenbegeleiding ${ }^{a}$

- bejaardentehuizen (geen psychogeriatrie) $22 \%$

- verpleeghuizen (somatisch) $20 \%$

- verpleeghuizen (psychisch) $16 \%$

- tehuizen voor geestelijk/dubbel gehandicapten $13 \%$

- detailhandel levensmiddelen $6 \%$

- overige branches $23 \%$

$\begin{array}{ll}\text { Totaal } & \overline{100 \%}\end{array}$

Branches MBO sociale arbeid

- algemeen overheidsbestuur

- wettelijke sociale verzekeringsorganen

\begin{tabular}{lr} 
- algemene banken & $14 \%$ \\
\hline & $9 \%$
\end{tabular}

- uitzendbureau $\quad 9 \%$

- detailhandel levensmiddelen $\quad 6 \%$

- overige branches $\quad 41 \%$

$\begin{array}{ll}\text { Totaal } & \overline{100 \%}\end{array}$

$\begin{array}{ll}\text { Branches HBO sociaal-pedagogisch } & \\ \text { - zwakzinnigeninrichtingen } & 21 \%\end{array}$

- niet-medische dagverblijven $13 \%$

- opvangtehuizen $11 \%$

- psychiatrische ziekenhuizen $\quad 8 \%$

- kinderdagverblijven/peuterspeelzalen/buitenschoolse opvang $5 \%$

- overige branches $\quad 42 \%$

$\begin{array}{ll}\text { Totaal } & \overline{100 \%}\end{array}$

${ }^{a}$ : branche-indeling conform CBS standaard bedrijfsindeling (SBI), 1978

b: branche-indeling conform CBS standaard bedrijfsindeling (SBI), 1993

Bron: ROA (RUBS/HBO-Monitor) 
Tabel $3.12 c$

Belangrijkste beroepen werkende schoolverlaters, per opleiding, 1994 (minimum aandeel 5\%)

Beroepen MBO agogisch ${ }^{\mathrm{a}}$

- kinderverzorger crèche/particulier e.d.

- leerlingverpleegkundige $A / B / Z$

- zieken-/zwakzinnigenverzorger (van volwassenen)

- winkelbediende/verkoper detailhandel

- klasse-/onderwijsassistent

- overige beroepen

Totaal

Beroepen MBO verzorging

- bejaardenverzorger in tehuizen e.d.

- zieken-/zwakzinnigenverzorger (in opleiding)

- kraamverzorger (gediplomeerd) $16 \%$

- leerlingverpleegkundige $A / B / Z \quad 11 \%$

- gezinsverzorger (in dienst van maatsch. organisatie) $11 \%$

- zieken-/zwakzinnigenverzorger (van volwassenen) $\quad 5 \%$

- overige beroepen $14 \%$

$\begin{array}{ll}\text { Totaal } & \overline{100 \%}\end{array}$

Beroepen MBO activiteitenbegeleiding ${ }^{\mathrm{a}}$

- activiteitenbegeleider/spelleider

- winkelbediende/verkoper detailhandel

- overige beroepen

Totaal

Beroepen MBO sociale arbeid ${ }^{\mathrm{a}}$

- maatschappelijk werker, consulent sociale voorzieningen

- administratief/secretarieel medewerker

- personeelsadministratie-employé

- arbeidsbemiddelaar, intercedent

$7 \%$

- winkel-/theatercassière/kasjuffrouw $6 \%$

- verzekeringsemployé

$5 \%$

- overige beroepen

$37 \%$

Totaal

$\overline{100 \%}$

Beroepen HBO sociaal-pedagogisch ${ }^{\mathrm{b}}$

- groepsleider (hoger niveau)

- zwakzinnigenverzorger

- activiteitenbegeleider

- maatschappelijk/cultureel werker

$10 \%$

- groepsleider crèche/peuterspeelzaal $\quad 10 \%$

$\begin{array}{ll}\text { - overige beroepen } & 26 \%\end{array}$

Totaal

$\overline{100 \%}$

a: beroepenindeling conform CBS Beroepenclassificatie, 1984

: beroepenindeling conform CBS Standaard Beroepenclassificatie (SBC), 1992

Bron: ROA (RUBS/HBO-Monitor) 
Tabel 3.12b en 3.12c laten de belangrijkste branches (b) en beroepen (c) voor de werkende schoolverlaters zien. Bij het RUBS-project uit 1994 zijn de genoemde beroepen en branches conform de Beroepenclassificatie 1984 en de Standaard Bedrijfsindeling 1978 ingedeeld, terwijl hiervoor bij de HBO-Monitor 1994 reeds de nieuwe Standaard Beroepenclassificatie 1992 en de herziene Standaard Bedrijfsindeling 1993 zijn gehanteerd.

Een belangrijk deel van de werkende schoolverlaters met een sociaal-agogische opleidingsachtergrond komt terecht in de zorg- en welzijnssector en/of in een sociaal-agogisch beroep. Alleen bij het MBO sociale arbeid is het aandeel schoolverlaters dat in de zorg- en welzijnssector of een sociaal-agogisch beroep werkzaam is relatief gering. Bij MBO verzorging en MBO activiteitenbegeleiding is het aandeel dat in de voor hen bedoelde domeinen een baan vindt juist relatief hoog.

\subsubsection{Werving, selectie en functie-eisen}

Werving en selectie werkgevers Noord-Nederland

Welke opleidings- en werkervaringseisen stellen werkgevers nu aan kandidaten voor sociaal-agogische functies in de zorg- en welzijnssector? Deze vraag is voorgelegd aan werkgevers in de zorg- en welzijnssector in Noord-Nederland.

Figuur 3.13a

Vereiste opleidingsniveau bij werving en selectie voor sociaal-agogische functies door werkgevers in de sector zorg en welzijn in Noord-Nederland, 1991

werving en selectie/ opleidingsvereiste

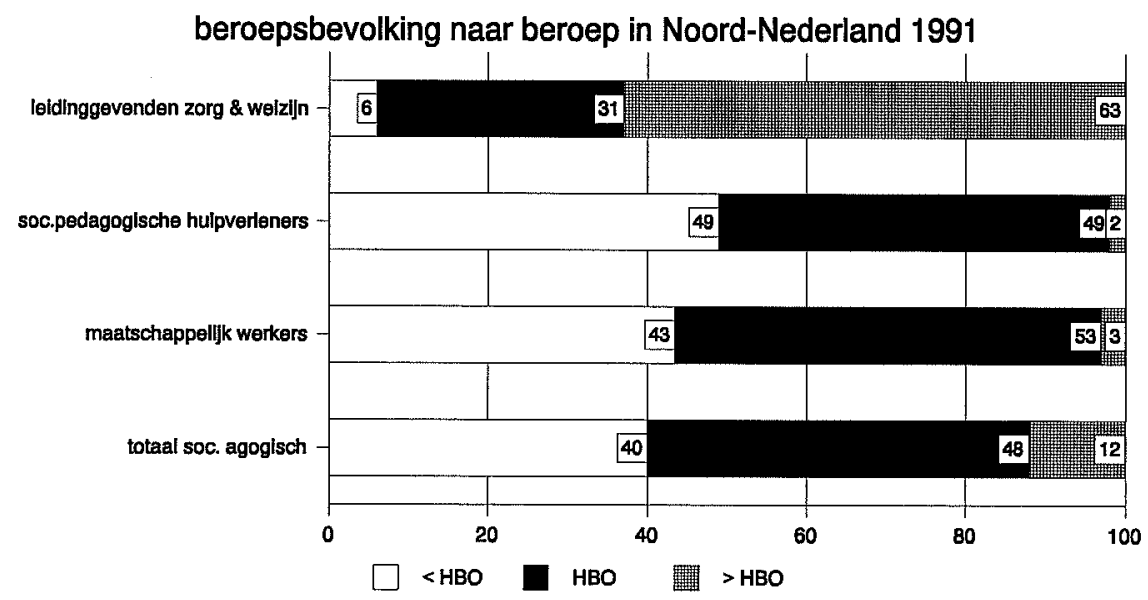

Bron: ROA 
De werkgevers hebben voor diverse sociaal-agogische beroepen het aantal personen aangegeven dat in 1991 met een bepaalde vooropleiding de organisatie is binnengekomen. Het gaat hier om de hoogst genoten voltooide opleiding van de werknemer. Door te vragen naar het opleidingsprofiel van de instroom ontstaat het beste inzicht in de selectie-eisen die tegenwoordig feitelijk aan bepaalde categorieën van sociaal-agogisch personeel worden gesteld.

Van het totale aantal dat in in 1991 (langs externe weg) bij de onderzochte werkgevers in Noord-Nederland in sociaal-agogische functies is ingestroomd heeft bijna de helft (48\%) een (meestal sociaal-agogische) initiële HBO-opleiding voltooid. De HBO'ers ondervinden in deze functies echter een geduchte concurrentie van afgestudeerde MBO'ers: twee op de vijf instromers heeft namelijk maximaal een (sociaal-culturele) MBO-opleiding gevolgd. $\mathrm{Bij}$ de sociaal-pedagogische hulpverleners worden zelfs evenveel MBO'ers als HBO'ers aangenomen (49\%). Uiteraard laat dit onverlet dat in de feitelijke beroepsuitoefening de HBO'ers wellicht vaker de banen krijgen met een grotere verantwoordelijkheid en meer doorgroeimogelijkheden. Doch ook hier lijkt een plafond te bestaan. Van degenen die in 1991 als leidinggevende zijn aangenomen had bijna tweederde (63\%) een universitaire of voortgezette HBO-opleiding afgerond, terwijl $31 \%$ een (sociaalagogische) opleiding op HBO-niveau had voltooid.

Uit het onderzoek onder de Noord-Nederlandse werkgevers in de zorg- en welzijnssector blijkt verder dat de kleine organisaties (tot 10 werknemers) naar verhouding veel sociaal-agogisch personeel met maximaal een MBO-diploma aangenomen te hebben. Middelgrote organisaties werven met name onder de afgestudeerden van het initiële HBO. Dit zou erop kunnen wijzen dat de kleine organisaties niet voldoende kunnen concurreren met de middelgrote organisaties, zodat zij genoegen moeten nemen met het minder gekwalificeerde aanbod.

Om enig inzicht te kunnen krijgen in hoeverre banen voor sociaal-agogische beroepen beschikbaar zijn voor pas afgestudeerden, is de werkgevers ook gevraagd het aantal personen aan te geven dat in 1991 met een bepaalde mate van werkervaring de organisatie is binnengekomen. Gemiddeld blijkt bijna de helft (49\%) van het aangenomen sociaal-agogisch personeel één $t / m$ vijf jaar werkervaring te hebben.

Een kwart (25\%) van de banen in de Noord-Nederlandse zorg-en welzijnssector kwam beschikbaar voor mensen met minder dan één jaar werkervaring, terwijl een kwart $(26 \%)$ van de vrijgekomen banen is ingevuld door werknemers die meer dan vijf jaar werkervaring hadden. Zoals wellicht verwacht kon worden heeft maar liefst $47 \%$ van de in 1991 ingestroomde leidinggevenden meer dan vijf jaar werkervaring. 
Bij de instroom van sociaal-pedagogische hulpverleners is met name het percentage met een middellange werkervaring met $61 \%$ relatief hoog.

De grote organisaties (met minimaal 50 werknemers) blijken naar verhouding vaker sociaal-agogisch personeel met minder dan een jaar werkervaring aangesteld te hebben, dan de kleine en middelgrote instellingen. In grotere organisaties kunnen mensen met weinig of geen werkervaring blijkbaar makkelijker worden ingepast, dan in kleinere organisaties, waarbij het nieuwe personeel vaker direct volledig inzetbaar moet kunnen zijn.

Ten slotte hebben de werkgevers voor ieder beroepencluster het aantal personen vermeld dat in 1991 intern dan wel extern is geworven. In 1991 is tweederde (66\%) van de vrijgekomen banen voor sociaal-agogisch personeel opgevuld door kandidaten buiten de eigen organisatie. De sociaal-pedagogische hulpverleners zijn daarentegen relatief vaak (42\%) binnen de eigen organisatie geworven. De in 1991 aangenomen maatschappelijk werkers en leidinggevenden in de zorg- en welzijnssector komen voor het grootste gedeelte via de externe arbeidsmarkt (respectievelijk $71 \%$ en $86 \%$ ).

Figuur 3.13b

Vereiste werkervaring bij werving en selectie voor sociaal-agogische functies door werkgevers in de sector zorg en welzijn in Noord-Nederland, 1991

\section{werving en selectie/ervaringsvereisten}

beroepsbevolking naar beroep in Noord-Nederland 1991

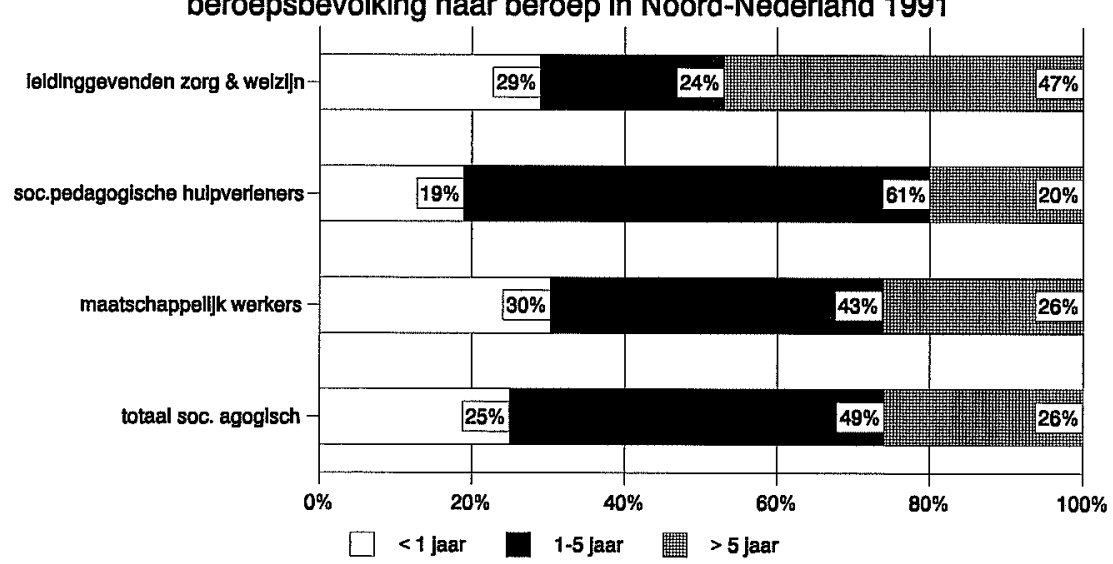

Bron: ROA 
Figuur $3.13 c$

Wervingskanaal bij werving en selectie voor sociaal-agogische functies door werkgevers in de sector zorg en welzijn in Noord-Nederland, 1991

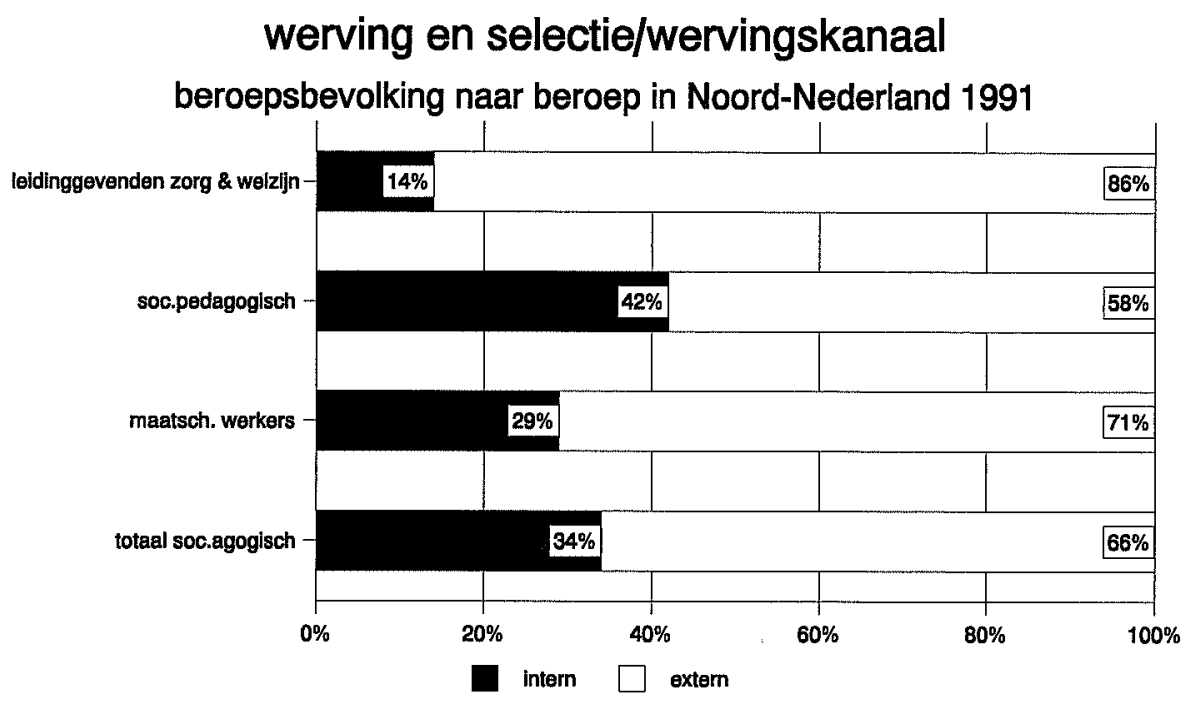

Bron: ROA

\subsubsection{Arbeidsvoorwaarden: werkweek, baanzekerheid, inkomen}

In deze paragraaf worden indicaties gegeven van de arbeidsvoorwaarden die midden jaren negentig voor nieuwkomers in de zorg- en welzijnssector gebruikelijk blijken te zijn. Achtereenvolgens komen de vraagstukken van deeltijdarbeid, baanzekerheid (geredeneerd vanuit de aanbodzijde) of flexibiliteit (geredeneerd vanuit de vraagzijde), evenals de verdiende lonen aan bod.

\section{Full-time versus part-time}

In vergelijking met de afgestudeerden van het MBO en $\mathrm{HBO}$ in totaal, werken de schoolverlaters van de sociaal-agogische beroepsopleidingen relatief vaak in deeltijd. Deeltijders betreffen degenen die minder dan 34 uur per week werkzaam zijn. Hierbij wordt geen onderscheid gemaakt tussen de grote en kleine deeltijdbaan. Binnen het MDGO varieert het percentage deeltijders (met een baan van maximaal 34 uur per week) van $39 \%$ voor de schoolverlaters van MBO sociale arbeid tot $67 \%$ voor de gediplomeerden van MBO activiteitenbegeleiding. Bij het HSAO is het percentage deeltijders met $52 \%$ relatief hoog, terwijl dit percentage voor de HBO-opleiding sociaal-pedagogische hulpverlening met $60 \%$ zelfs nog iets hoger ligt. 
Figuur 3.14

In voltijd- en deeltijd werkende schoolverlaters van het MBO en HBO uit het studiejaar $1992 / 1993$

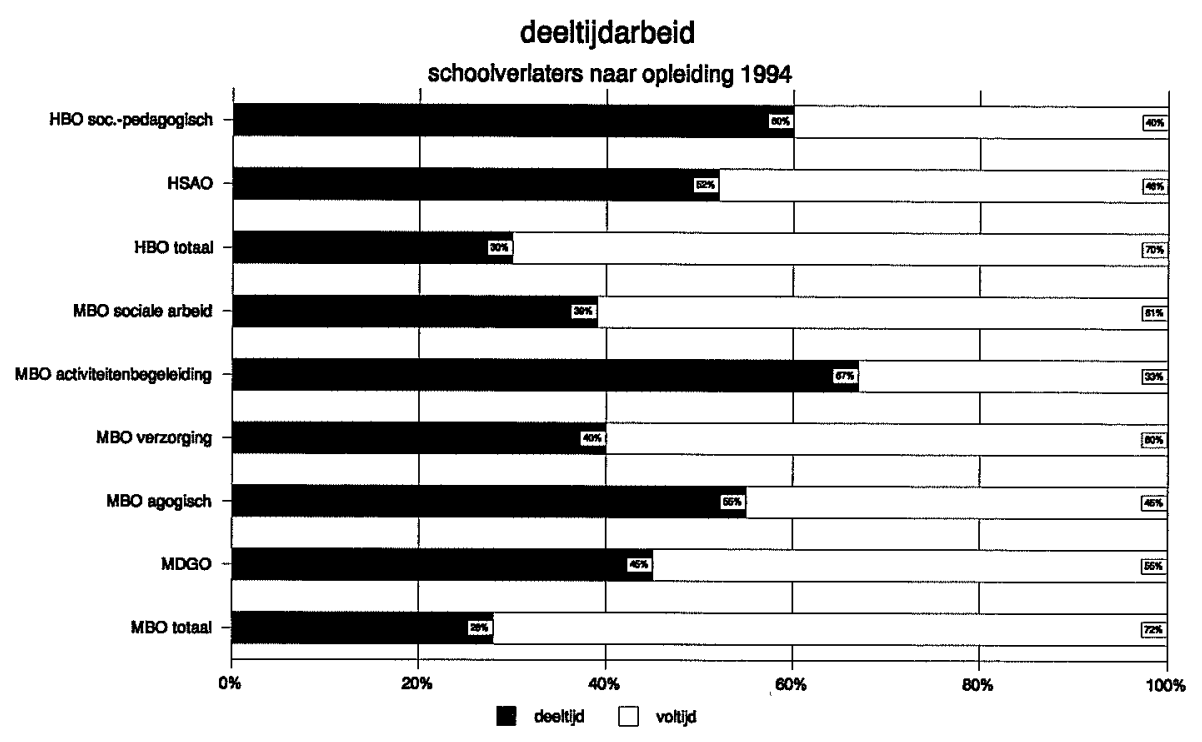

Bron: ROA (RUBS/HBO-Monitor)

Zoals eerder vermeld is het hoge percentage deeltijders bij de werkenden met een sociaal-culturele opleidingsachtergrond niet louter te verklaren uit het feit dat de vrouwen in deze opleidingssector sterk zijn oververtegenwoordigd. Ook de mannen met een dergelijke opleidingsachtergrond werken vaker in deeltijd dan mannen uit andere opleidingssectoren.

Er is sprake van een wisselwerking tussen sexe en de sector waarin men werkzaam is.

\section{Baanzekerheid / Flexibiliteit}

De afgelopen jaren is het aandeel schoolverlaters dat ruim een jaar na afstuderen reeds een vaste baan heeft, sterk gedaald. Vanuit het oogpunt van de werkgevers betekent dit dat op dit punt de arbeidsmarkt verder is geflexibiliseerd, voor de schoolverlaters is echter de baanzekerheid de laatste jaren afgenomen. Midden jaren negentig heeft ongeveer tweederde van de werkende schoolverlaters met een middelbare of hogere beroepsopleiding ongeveer een jaar na afstuderen een vaste baan. 
Figuur 3.15

Vaste en tijdelijke aanstellingen van werkende schoolverlaters van het MBO en $\mathrm{HBO}$ uit het studiejaar 1992/1993

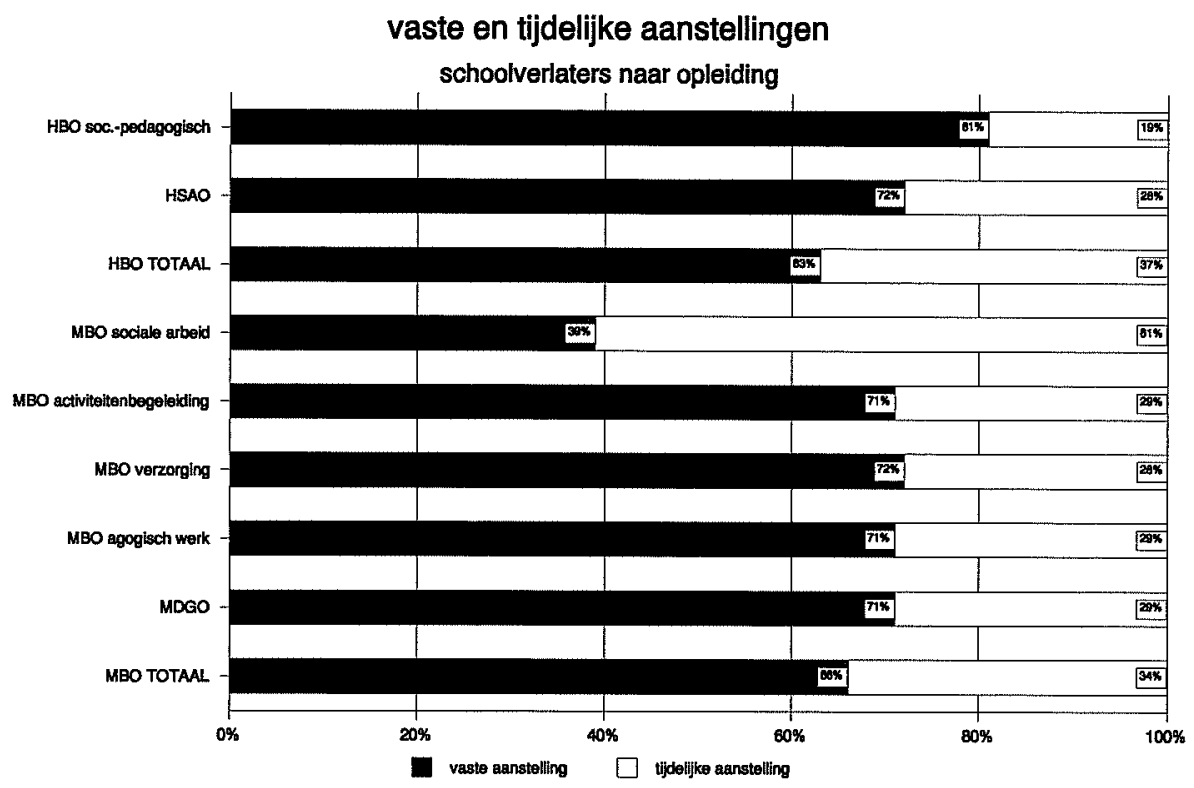

Bron: ROA (RUBS/HBO-Monitor)

Bij de sociaal-agogische opleidingen ligt het percentage schoolverlaters met een vaste aanstelling overigens bijna $10 \%$ hoger, op ruim $70 \%$. Bij de afgestudeerden van de $\mathrm{HBO}$-opleiding sociaal-pedagogische hulpverlening gaat het zelfs om $81 \%$ van de werkende afgestudeerden. Daarentegen heeft bij de MBO-opleiding sociale arbeid slechts $39 \%$ een vaste baan.

\section{Inkomen}

Ten slotte is nagegaan welk bruto maandsalaris en uurloon de schoolverlaters ruim een jaar na afstuderen met hun werkzaamheden verdienen.

In vergelijking met het totale MBO is het bruto maandsalaris (inclusief toeslagen voor onregelmatig werk, maar exclusief inkomsten voor overwerk) van de gediplomeerden van het MDGO laag. Binnen het MDGO varieert het gemiddeld bruto maandsalaris van 1610 gulden voor de afgestudeerden van MBO agogisch werk tot 1910 gulden van MBO sociale arbeid. Bij het $\mathrm{HBO}$ wordt geconstateerd dat de afgestudeerden van het HSAO een hoger maandsalaris hebben dan gemiddeld voor het totale $\mathrm{HBO}$ geldt. Binnen het HSAO zijn de maandelijkse verdiensten voor de afgestudeerden van sociaal-pedagogische hulpverlening echter fors lager. 
Figuur 3.16a

Gemiddeld bruto maandsalaris van werkende schoolverlaters van het MBO en HBO uit het studiejaar $1992 / 1993$

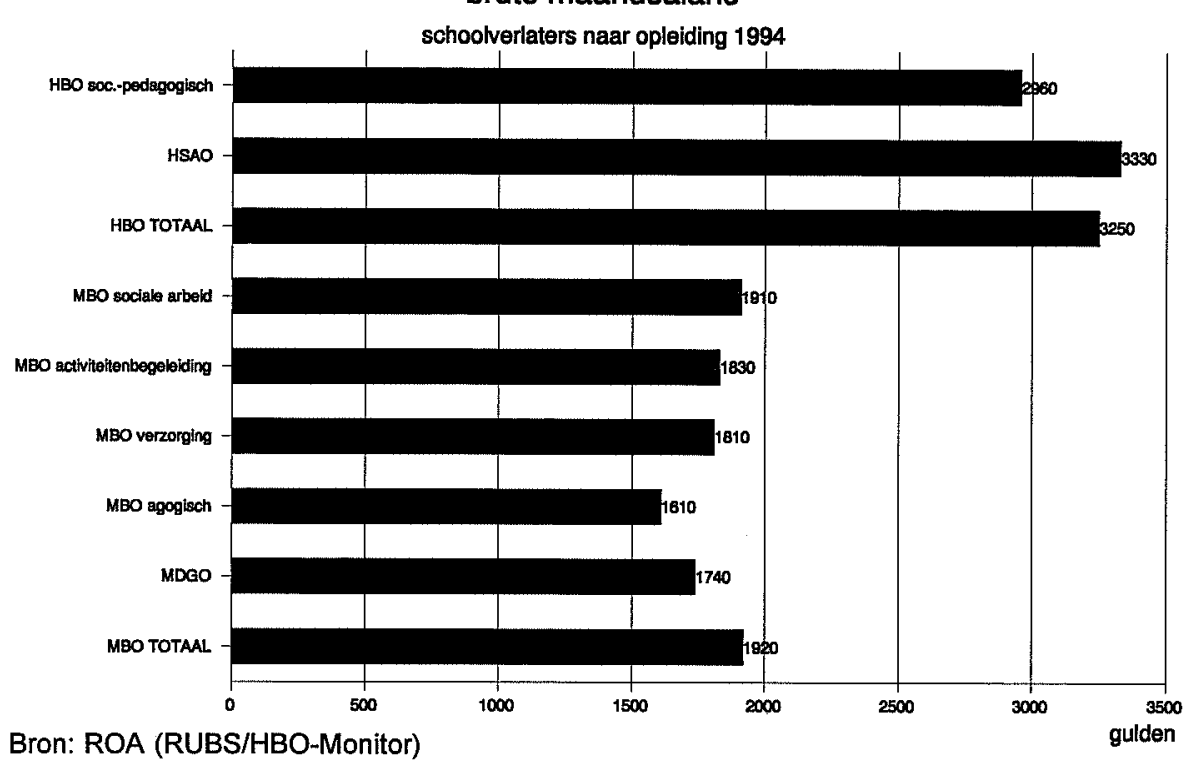

Een deel van de verschillen in maandsalaris kunnen worden toegeschreven aan de gemiddeld kortere werkweek van de afgestudeerden van het sociaal-agogisch onderwijs. Vandaar dat ook de bruto uurlonen zijn berekend. Echter ook dan blijken er nog behoorlijke loonverschillen te bestaan. Op MBO-niveau echter niet meer zozeer tussen de schoolverlaters van het MDGO en het MBO als totaal, maar juist binnen het MDGO zelf. De afgestudeerden van MBO activiteitenbegeleiding en sociale arbeid blijken een veel hoger uurloon te hebben dan de overige afgestudeerden van het MDGO (en het MBO).

Bij het HBO blijken de uurlonen voor de HSAO'ers eveneens relatief hoog te zijn. Ook teruggerekend naar het uurloon verdienen de afgestudeerden van de opleiding sociaal-pedagogische hulpverlening relatief weinig. Het verschil in inkomen tussen het HSAO en het HBO laat zich deels verklaren door het feit dat bij het HSAO het aandeel dat de opleiding in deeltijd heeft gevolgd veel hoger is dan bij het totale HBO het geval is. De voormalige deeltijd-studenten die vaak al langer (in het werkveld) werkzaam en doorgaans ook ouder zijn, verdienen per uur bijna 7,50 gulden meer dan de afgestudeerden van het voltijd-hbo. Het verschil in bruto uurloon tussen de afgestudeerden van het totale voltijd-hbo en het HSAO voltijd bedraagt namelijk maar 0,50 gulden (19,10 versus 19,60 bruto per uur). 
Figuur 3.16b

Gemiddeld bruto maandloon van werkende schoolverlaters van het MBO en HBO uit het studiejaar 1992/1993

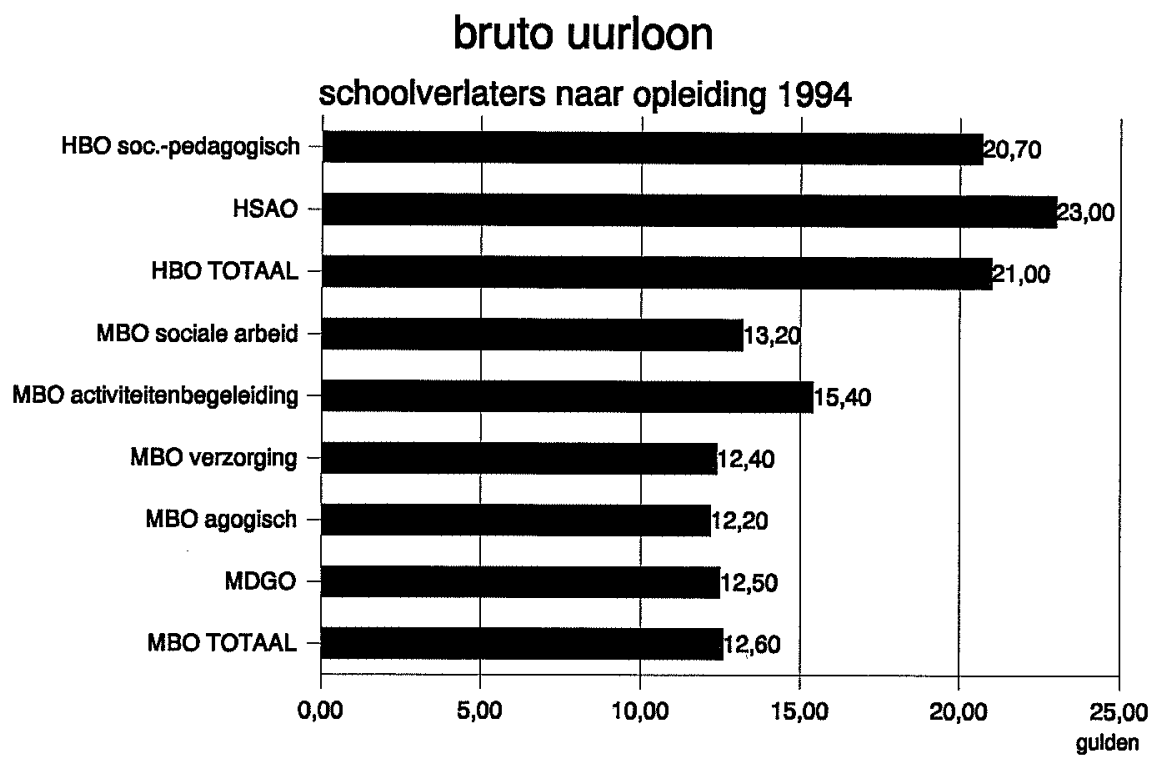

Bron: ROA (RUBS/HBO-Monitor)

\subsubsection{Ziekteverzuim}

De gegevens over het ziekteverzuim geven eveneens een indicatie van mogelijke knelpunten op de arbeidsmarkt in de zorg- en welzijnssector. Met name voor zover deze betrekking hebben op de kwaliteit en de zwaarte van het werk.

Uit figuur 3.17 blijkt dat het ziekteverzuim (inclusief bevallingsverlof) begin jaren negentig fors is gedaald. Deze ontwikkeling doet zich in alle sectoren voor, zowel bij de subsectoren van de maatschappelijke dienstverlening, als bij de sociaal-culturele instellingen en de intramurale gezondheidszorg. In 1994 varieerde het verzuimpercentage als gevolg van ziekte en bevalling tussen $5,5 \%$ voor de sector van de sociaal-culturele en culturele instellingen tot $9,5 \%$ voor de gezinsverzorging en de bejaardenhulpverlening. In de sector van de gezinszorg en de bejaardenhulpverlening is het ziekteverzuimpercentage naar verhouding licht afgenomen, zodat het verzuimpercentage van deze sector midden jaren negentig relatief gezien nog steeds bijzonder hoog is. In de andere sectoren is het verzuimpercentage begin jaren negentig namelijk sterker gedaald. 
Figuur 3.17

Verzuim wegens ziekte en bevalling per sector, 1990-1992-1994

\section{ziekteverzuim}

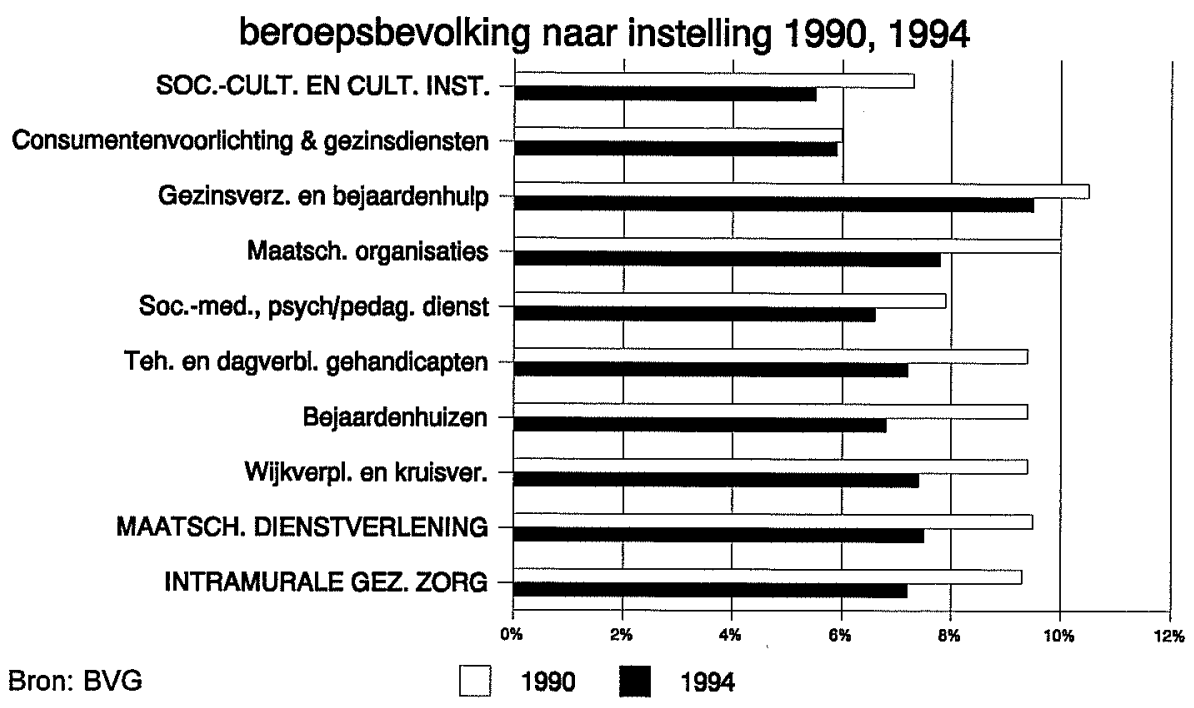

\subsubsection{Personeelsverloop}

Wanneer een verhoudingsgewijs hoog percentage nieuwkomers op een bepaald arbeidsmarktsegment op zoek is naar een andere betaalde baan, kan dit op instabiele arbeidsrelaties en mogelijk ook op relatief veel arbeidsonvrede duiden. Een laag percentage werkenden dat op zoek is naar een andere baan kan daarentegen op een relatief sterke arbeidsmarktpositie van deze werkenden wijzen en een grotere tevredenheid met de baan die men op dat moment heeft. Hierbij dient men zich overigens wel te realiseren dat de (potentiële) baanmobiliteit ook afhankelijk is van de mate waarin er uitwijkmogelijkheden bestaan voor de werknemers met een bepaalde beroepservaring of opleidingsachtergrond, en van de mate van variatie in arbeidsvoorwaarden in de sectoren waarin bepaalde beroepsbeoefenaren terecht kunnen komen.

Tabel 3.18 laat zien dat het met name de werkende schoolverlaters van de MBOopleidingen activiteitenbegeleiding en sociale arbeid zijn die het afgelopen half jaar relatief vaak activiteiten hebben ondernomen om een andere baan te vinden. Daarentegen zijn de afgestudeerden van de MBO-opleiding verzorging beduidend minder vaak op zoek geweest naar een nieuwe werkkring. Op HBO-niveau zijn er geen verschillen tussen het totaal HBO en de sociaal-agogische opleidingen wat 
betreft het aandeel dat het afgelopen half jaar op zoek is geweest naar een andere baan.

Tabel 3.18

Potentiële baanmobiliteit van werkende schoolverlaters van het MBO en HBO uit het studiejaar 1992/1993

\begin{tabular}{lll}
\hline & $\begin{array}{c}\text { Op zoek naar ander werk? } \\
\text { afgelopen } \\
\text { half jaar }\end{array}$ & $\begin{array}{c}\text { ook afgelopen } \\
\text { vier weken }\end{array}$ \\
\hline Opleiding & & \\
Totaal MBO & & $56 \%$ \\
MDGO & $41 \%$ & $53 \%$ \\
MBO agogisch werk & $36 \%$ & $51 \%$ \\
MBO verzorging & $41 \%$ & $49 \%$ \\
MBO activiteitenbegeleidig & $29 \%$ & $46 \%$ \\
MBO sociale arbeid & $51 \%$ & $54 \%$ \\
Totaal HBO & $58 \%$ & $54 \%$ \\
HSAO & $44 \%$ & $58 \%$ \\
HBO sociaal-pedagogisch & $45 \%$ & $58 \%$ \\
\hline Bron: CBS/ROA & $43 \%$ & \\
\hline
\end{tabular}

Bron: CBS/ROA

In tabel 3.18 staat ook het procentuele aandeel werkenden aangegeven dat de afgelopen vier weken nog steeds bezig was met het vinden van een nieuwe werkkring. Doorgaans gaat het hier om de helft van degenen die hebben gemeld het afgelopen half jaar op zoek te zijn geweest naar een andere betaalde baan. Tussen de opleidingen lopen de percentages slechts in geringe mate uiteen.

Met name in perioden van krapte op de arbeidsmarkt is een beheersing van het personeelsverloop voor de zorginstellingen van groot belang. Immers, voor ieder personeelslid dat vertrekt uit de instelling moet op de - dan al krappe - arbeidsmarkt weer een nieuwe beroepskracht worden geworven. Ook het feitelijke personeelsverloop kan worden opgevat als een indicatie voor de arbeidssatisfactie van de werkenden.

Pool e.a., (1992), geven aan dat er een samenhang bestaat tussen de omvang van het aantal moeilijk vervulbare vacatures, het ziekteverzuim en het personeelsverloop. In organisaties waar het werkklimaat niet goed is, is het ziekteverzuim en het personeelsverloop doorgaans hoog en is het vaak moeilijk om aan nieuw personeel te komen. 
Het moeilijk vervullen van de opengevallen plaatsen, versterkt de werkdruk op het blijvende personeel, zodat het ziekteverzuim en het verloop verder toeneemt; een zichzelf versterkend proces aldus.

Het panelonderzoek onder de werkgevers in de zorg- en welzijnssector in NoordNederland geeft inzicht in de feitelijke beroepsmobiliteit onder het sociaal-agogisch personeel. Voor ieder beroepencluster dat in de organisatie is vertegenwoordigd hebben de werkgevers het aantal mannelijke en vrouwelijke werknemers ingevuld dat in een bepaalde leeftijdsklasse ${ }^{9}$ voorkomt. Zij hebben deze aantallen zowel aangegeven voor het totaal dat eind 1991 in de organisatie werkzaam was, alsmede voor het betreffende aantal werknemers dat gedurende 1991 de organisatie heeft verlaten (= uitstroom), dan wel de organisatie in 1991 is binnengekomen ( $=$ instroom).

Met behulp van deze gegevens kan inzicht worden verkregen in de mobiliteit van bepaalde categorieën werknemers en kan de uitbreidings- en vervangingsvraag die de organisaties het afgelopen jaar hebben gekend worden berekend (zie ook hoofdstuk 3). Voor de overzichtelijkheid is het aantal leeftijdsklassen tot een drietal teruggebracht.

Uit de literatuur blijkt dat met name vrouwen rond hun dertigste (gedeeltelijk ${ }^{10}$ ) de arbeidsmarkt verlaten om meer tijd te kunnen besteden aan gezinsverzorgende taken. Tussen de 30 en 50 jaar blijt het percentage werkenden vrij stabiel, terwijl na het vijftigste levensjaar het aandeel dat via ondermeer de WAO of VUT de arbeidsmarkt verlaat snel toeneemt. De instroom is enerzijds groot bij de leeftijdsklasse onder de 30 jaar, aangezien schoolverlaters dan de arbeidsmarkt betreden. Vanuit het perspectief van de organisatie is er ook nog een behoorlijke instroom van mensen tussen de 30 en 50 jaar waarvan het merendeel al heeft gewerkt bij een andere organisatie. De instroom van 50-plussers is zeer gering. Vandaar dat deze drie leeftijdsklassen worden onderscheiden. In figuur $3.19 \mathrm{zijn}$ voor het totaal van het sociaal-agogisch personeel en de sociaal-pedagogische hulpverleners de uitstroom- en instroomgegevens weergegeven, evenals het aantal werknemers dat eind 1991 in een dergelijke functie werkzaam was. De gegevens zijn naar sexe en leeftijd onderverdeeld en gesommeerd over alle onderzochte organisaties.

9. Het ging hierbij om de volgende leeftijdsklassen: minder dan 20 jaar, 20-24 jaar, 25-29 jaar, 30-39 jaar, 40-49 jaar, 50-59 jaar en 60 jaar en ouder.

10. In dit onderzoek is alleen een volledige terugtrekking van een werknemer zichtbaar. Indien iemand van een voltijdse dienstbetrekking overschakelt op een deeltijdbaan is dit niet terug te vinden in de uitstroomgegevens. 
Aan het begin van 1991 waren er in de onderzochte zorg- en welzijnsorganisaties in Noord-Nederland $1380(=1415-151+116)$ werknemers in sociaal-agogische functies werkzaam. Het mobiliteitspercentage in 1991 bedroeg $8,4 \%$; van deze 1380 werknemers zijn namelijk 116 personen uitgestroomd uit de organisatie. Zij hebben òf een al dan niet vergelijkbare functie in een andere organisatie aanvaard, of zij zijn al dan niet vrijwillig uit het arbeidsproces getreden. Er blijkt geen noemenswaardig verschil in mobiliteit tussen mannen en vrouwen te bestaan $(8,5$ versus 8,3 procent).

Er bestaan wel grote mobiliteitsverschillen tussen de leeftijdsklassen. Terwijl in de jongste leeftijdsklasse het mobiliteitspercentage $12,3 \%$ en in de oudste klasse zelfs $14,5 \%$ bedraagt, is het percentage voor het sociaal-agogisch personeel tussen de 30 en 50 jaar slechts de helft hiervan: namelijk $6,4 \%$.

Het hoge percentage bij de ouderen duidt op een forse uittrede uit de arbeidsmarkt. De jongeren zijn daarentegen duidelijk nog op zoek naar een passende baan, waarbij niet uitgesloten moet worden dat dit een gevolg is van onvrijwillig 'jobhoppen' van de ene tijdelijke baan naar de andere tijdelijke baan. Ruim een kwart van de afgestudeerde HSAO'ers blijkt namelijk een tijdelijke baan te hebben. Bij driekwart hiervan gaat het om een contract dat maximaal één jaar duurt (zie Van de Loo, Ramaekers en Van der Velden, 1992).

De instroom van werknemers blijkt de uitstroom te overtreffen (151-116). De werkgelegenheid voor sociaal-agogische functies is in de organisaties met 35 werknemers gegroeid; dat is ten opzichte van het begin van 1991 een groei van ruim $2,5 \%$. In theorie zou het zo kunnen zijn dat het aantal formatieplaatsen echter gelijk is gebleven, omdat in de organisatie meer mensen in deeltijd zijn gaan werken $^{11}$. Hoewel dit wellicht ook een rol heeft gespeeld, lijkt deze groei van het personeelsbestand in de eerste plaats op een uitbreiding van de werkgelegenheid te duiden.

De overige 116 ingestroomde werknemers dienden ter vervanging van uitgestroomd sociaal-agogisch personeel. Deze component van de instroom was dus ruim drie maal zo groot als het deel dat de werkgelegenheidsgroei afdekte. In hoofdstuk 3 zal nader worden ingegaan op de toekomstige vervangingsvraag van sociaal-agogisch personeel.

11. Bij een jaarlijkse herhaling van het onderzoek kan worden nagegaan of het aantal formatieplaatsen al dan niet gelijk is gebleven. 
Een nadere beschouwing van tabel 3.19 laat zien dat de werkgelegenheidsgroei geheel is toe te schrijven aan een toename van de werkgelegenheid voor vrouwen. Het aantal vrouwen is in 1991 per saldo met 49 werknemers toegenomen, terwijl het aantal mannen in deze periode per saldo met 14 afnam. De vrouwen zijn hun achterstand de laatste jaren snel aan het inlopen, alhoewel (nog steeds) meer dan de helft $(55 \%)$ van het totale sociaal-agogisch personeel uit mannen bestaat. Uitgedrukt in formatieplaatsen zou het verschil tussen mannen en vrouwen nog groter kunnen zijn, aangezien vrouwen vaker in deeltijd werken dan mannen.

Tabel 3.19

Ontwikkelingen in omvang en samenstelling sociaal-agogische functies in 1991

\begin{tabular}{|c|c|c|c|c|}
\hline & \multicolumn{4}{|c|}{$\begin{array}{l}\text { Beroepencluster } \\
\text { Leeftijdsklassen }\end{array}$} \\
\hline & \multicolumn{4}{|c|}{ Totaal Sociaal-agogisch personeel } \\
\hline Uitstroom 1991 & $<30$ jaar & 30 tot 50 jaar & $\geq 50$ jaar & totaal \\
\hline $\begin{array}{l}\text { mannen } \\
\text { vrouwen } \\
\text { totaal }\end{array}$ & $\begin{array}{l}12 \\
23 \\
35\end{array}$ & $\begin{array}{l}40 \\
21 \\
61\end{array}$ & $\begin{array}{r}15 \\
5 \\
20\end{array}$ & $\begin{array}{r}67 \\
49 \\
116\end{array}$ \\
\hline $\begin{array}{l}\text { Instroom } 1991 \\
\text { mannen } \\
\text { vrouwen } \\
\text { totaal }\end{array}$ & $\begin{array}{l}20 \\
50 \\
70\end{array}$ & $\begin{array}{l}31 \\
47 \\
78\end{array}$ & $\begin{array}{l}2 \\
1 \\
3\end{array}$ & $\begin{array}{r}53 \\
98 \\
151\end{array}$ \\
\hline \multirow[t]{3}{*}{$\begin{array}{l}\text { Situatie eind } 1991 \\
\text { mannen } \\
\text { vrouwen } \\
\text { totaal }\end{array}$} & $\begin{array}{l}107 \\
213 \\
320\end{array}$ & $\begin{array}{l}570 \\
404 \\
974\end{array}$ & $\begin{array}{r}101 \\
20 \\
121\end{array}$ & $\begin{array}{r}778 \\
637 \\
1415\end{array}$ \\
\hline & \multicolumn{4}{|c|}{ Sociaal-pedagogische hulpverleners } \\
\hline & $<30$ jaar & 30 tot 50 jaar & $\geq 50$ jaar & totaal \\
\hline $\begin{array}{l}\text { Uitstroom } 1991 \\
\text { mannen } \\
\text { vrouwen } \\
\text { totaal }\end{array}$ & $\begin{array}{l}12 \\
16 \\
28\end{array}$ & $\begin{array}{l}19 \\
12 \\
31\end{array}$ & $\begin{array}{l}7 \\
1 \\
8\end{array}$ & $\begin{array}{l}38 \\
29 \\
67\end{array}$ \\
\hline $\begin{array}{l}\text { Instroom } 1991 \\
\text { mannen } \\
\text { vrouwen } \\
\text { totaal }\end{array}$ & $\begin{array}{l}18 \\
26 \\
44\end{array}$ & $\begin{array}{l}16 \\
22 \\
38\end{array}$ & $\begin{array}{l}2 \\
0 \\
2\end{array}$ & $\begin{array}{l}36 \\
48 \\
84\end{array}$ \\
\hline $\begin{array}{l}\text { Situatie eind } 1991 \\
\text { mannen } \\
\text { vrouwen } \\
\text { totaal }\end{array}$ & $\begin{array}{r}72 \\
146 \\
218\end{array}$ & $\begin{array}{l}219 \\
184 \\
403\end{array}$ & $\begin{array}{r}35 \\
4 \\
39\end{array}$ & $\begin{array}{l}326 \\
334 \\
660\end{array}$ \\
\hline
\end{tabular}

Bron: ROA 
Terwijl in de leeftijdsklasse van 50 jaar en ouder vrouwen nog geen $17 \%$ van het sociaal-agogisch personeel uitmaken, is het percentage vrouwen in de leeftijdsklasse van 30 tot 50 jaar ruim $41 \%$ en vormen vrouwen in de leeftijdsklasse tot 30 jaar met tweederde de meerderheid. Dit laatste komt overigens aardig overeen met de man-/vrouwverhouding bij de afgestudeerde HSAO'ers uit het studiejaar 1989/90; het percentage vrouwen bedraagt hier 71\% (zie Van de Loo, Ramaekers en Van der Velden, 1992). Hiermee lijkt de opmars van vrouwen in sociaal-agogische functies met name aanbodgestuurd; vrouwen bieden zich veel vaker op de arbeidsmarkt aan, dus is het logisch dat vrouwen vaker worden aangenomen.

Zoals verwacht wordt de - voornamelijk mannelijke - uitstroom in de leeftijdsklasse van 50 jaar en ouder nauwelijks gecompenseerd door instroom, zodat het verschil daar negatief is en de werkgelegenheid, gemeten in het aantal werknemers, in die klasse dus afneemt. Daarentegen neemt het aandeel jongeren tot 30 jaar sterk toe, terwijl in de leeftijdscategorie alleen het aantal vrouwen toeneemt.

De beroepsmobiliteit van het sociaal-agogisch personee ${ }^{12}$ is niet alleen voor het totaal van deze beroepsklasse onderzocht, maar ook voor de sociaal-pedagogische hulpverleners afzonderlijk. Het mobiliteitspercentage bedraagt voor deze groep $10,4 \%$, hetgeen $2 \%$ hoger ligt dan voor het het totale sociaal-agogisch personeel is berekend. In 1991 heeft de instroom de uitstroom van sociaal-pedagogisch hulpverleners overtroffen. Voorts geldt ook bij deze beroepsgroep dat alleen voor vrouwen het verschil tussen in- en uitstroom positief is. Ten slotte nog een opmerking over de leeftijdsopbouw van deze beroepsgroep. In vergelijking met de andere beroepsgroepen bij het sociaal-agogisch personeel zijn bij de sociaalpedagogisch hulpverleners de jongeren relatief sterk vertegenwoord: éénderde is namelijk jonger dan 30 jaar.

12. Binnen de beroepsklasse van sociaal-agogisch personeel vormen de sociaal-pedagogisch hulpverleners $(47 \%)$, maatschappelijk werkers $(33 \%)$ en de leidinggevenden zorg- en welzijn $(13 \%)$ de belangrijkste beroepsgroepen. De overige $7 \%$ bestaat uit cultureel werkers, beleidsmedewerkers en personeelswerkers voor zover deze laatste in de zorgen welzijnssector werkzaam zijn. 


\title{
4 Toekomstig arbeidsmarktperspectief zorg- en welzijnssector
}

\begin{abstract}
4.1 Inleiding
Terwijl in het vorige hoofdstuk de actuele arbeidsmarktpositie van de beroepsbeoefenaren is besproken, gaat het in dit hoofdstuk over de toekomstige arbeidsmarktontwikkelingen op de middellange termijn. ${ }^{13}$ De prognoses hebben betrekking op de periode 1995-2000. Zo kunnen mensen die nu op het punt staan hun studie- en beroepskeuze te maken, rekening houden met het arbeidsmarktperspectief op het moment dat zij deze studie afronden. Ook voor beleidsmakers, sociale partners, werk- en onderwijsveld zijn middellange termijn prognoses over een periode van viff jaar zinvol voor het afstemmen van het toekomstig beleid op de ingeschatte arbeidsmarktontwikkelingen.

De prognoses voor de arbeidsmarktontwikkelingen aan de vraag- en aanbodzijde op de arbeidsmarkt in de zorg-en welzijnssector zijn gebaseerd op de gegevens uit het informatiesysteem onderwijs-arbeidsmarkt dat het ROA de afgelopen jaren heeft ontwikkeld. Voor het informatiesysteem is bij het maken van de arbeidsmarktprognoses gekozen voor een stroomcijfer-aanpak. Bij deze aanpak worden prognoses gemaakt van de stromen van en naar de arbeidsmarkt in een bepaalde toekomstige periode (i.c. 1995-2000). Deze aanpak heeft als voordeel dat de processen in kaart worden gebracht die van belang zijn voor de ontwikkeling van vraag en aanbod op de arbeidsmarkt. De prognoses worden opgesteld voor in totaal 93 beroepsklassen en 79 opleidingstypen, gespreid over de volle breedte van de arbeidsmarkt.
\end{abstract}

Figuur 4.1 geeft een schematisch overzicht van het prognosemodel van het informatiesysteem onderwijs-arbeidsmarkt ${ }^{14}$. Een stroomgrootheid die van belang is voor de vraagzijde van de arbeidsmarkt is de uitbreidingsvraag, die de ontwikkeling weergeeft van de werkgelegenheid in een bepaalde beroepsklasse of voor een bepaald opleidingstype. De prognoses van de uitbreidingsvraag bouwen voort op de werkgelegenheidsprognoses voor bedrijfssectoren van het Centraal Planbureau. Omdat binnen een bedrijfssector bepaalde beroepsklassen zich sneller ontwikkelen dan andere, vertaalt het ROA deze bedrijfssectorontwikkelingen naar de uitbreidingsvraag per beroepsklasse. Vervolgens wordt bepaald welke implicaties de

13. ROA (1995), De arbeidsmarkt naar opleiding en beroep tot 2000, rapport (ROA-R-1995/3) en statistische bijlage (ROA-R-1995/3B).

14. Voor een uitgebreide toelichting wordt verwezen naar ROA, Methodiek van het Informatiesysteem Onderwijs-Arbeidsmarkt 1995, ROA-W-1995/3, Maastricht, 1995. 
voorspelde groei van de verschillende beroepsklassen heeft voor de uitbreidingsvraag per opleidingstype. Hierbij wordt rekening gehouden met het optreden van verschuivingen in de opleidingenstructuur van beroepsklassen. De uitbreidingsvraag per opleidingstype heeft betrekking op het aantal personen met een bepaalde opleidingsachtergrond, dat werkgevers zou willen aannemen. De feitelijke werkgelegenheidsontwikkeling per opleidingstype zal hier doorgaans van afwijken door de invloed van de ontwikkeling van het aanbod op de schaarsteverhoudingen en de als gevolg daarvan optredende substitutieprocessen.

Naast de uitbreidingsvraag is er op de arbeidsmarkt sprake van vervangingsvraag vanwege - al dan niet vervroegde - pensionering, arbeidsongeschiktheid, tijdelijke terugtreding van de arbeidsmarkt, beroepsmobiliteit e.d. Er wordt overigens alleen van vervangingsvraag gesproken voor zover het vertrek van een werknemer ook daadwerkelijk leidt tot een vacature voor een nieuwkomer. Als het vertrek van een arbeidskracht gebruikt wordt om een werkgelegenheidskrimp te effectueren, is er derhalve geen sprake van vervangingsvraag. Deze uitstroom is immers niet relevant voor nieuwkomers. Dit betekent dat niet de volledige arbeidsmarktuitstroom ook werkelijk leidt tot vervangingsvraag.

Bovendien bestaat er een belangrijk verschil tussen de vervangingsvraag per beroepsklasse en per opleidingstype. De beroepsmobiliteit is namelijk wel van invloed op de vervangingsvraag per beroepsklasse, maar heeft geen effect op de vervangingsvraag per opleidingstype. Het veranderen van beroep heeft immers geen gevolgen voor de opleidingsstructuur van de werkgelegenheid. Voorts is het van belang om te weten dat in de vervangingsvraag ook de herintrede van aanbieders op de arbeidsmarkt is begrepen. Deze kan echter niet afzonderlijk worden bepaald.

Bij een toename van de werkgelegenheid vormen de uitbreidingsvraag en de vervangingsvraag tezamen de baanopeningen voor nieuwkomers op de arbeidsmarkt. Bij een krimpende werkgelegenheid kan er alleen sprake zijn van baanopeningen uit hoofde van de vervangingsvraag.

Tegenover de totale vraag naar nieuwkomers staat het verwachte aanbod van nieuwkomers, bestaande uit de toekomstige instroom van schoolverlaters in de prognoseperiode en het nog boven de markt zwevende aanbod van kortdurig werklozen aan het begin van deze periode. Verondersteld wordt dat langdurig werklozen, die langer dan een jaar op zoek zijn naar werk, geen serieuze concurrentie voor schoolverlaters meer vormen. 
Figuur 4.1

Globale opzet prognosemodel ROA-informatiesysteem onderwijs-arbeidsmarkt

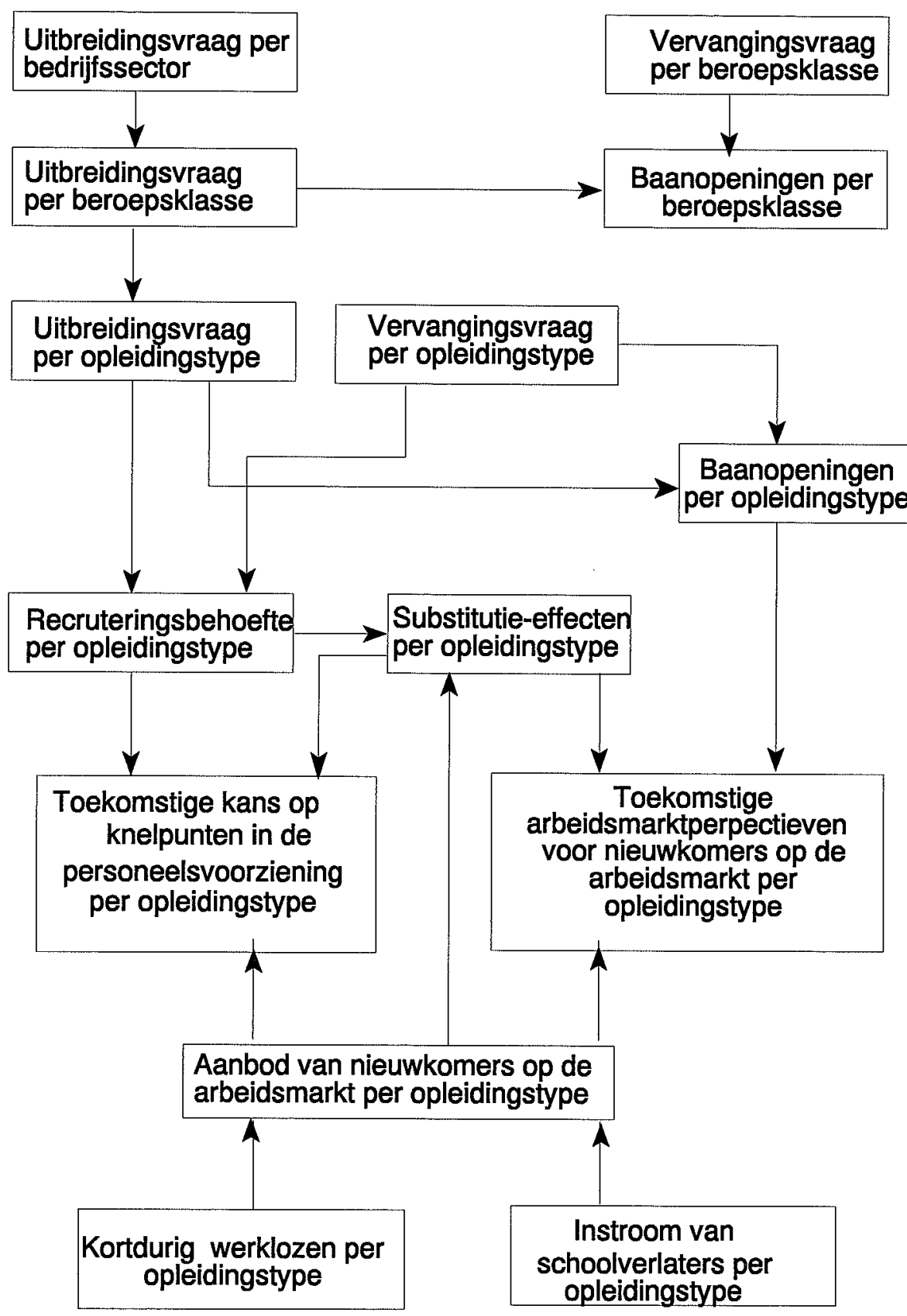


De prognoses van de instroom van schoolverlaters op de arbeidsmarkt corresponderen met de Referentieramingen 1995 van het Ministerie van Onderwijs, Cultuur en Wetenschappen voor het reguliere onderwijs. Door het ROA zijn deze prognoses nader verbijzonderd, en zijn op basis van aanvullende gegevens de effecten ingeschat van het niet-reguliere onderwijs op de opleidingsachtergrond van de instroom op de arbeidsmarkt. Tevens is rekening gehouden met de aanstaande afschaffing van de dienstplicht. Dit betekent dat in de prognoseperiode ongeveer 28.000 mannelijke schoolverlaters direct de arbeidsmarkt op stromen in plaats van eerst de dienstplicht te vervullen.

Door de verwachte vraag- en aanbodstromen met elkaar te confronteren wordt per opleidingstype een indicatie verkregen van de toekomstige arbeidsmarktperspectieven voor nieuwkomers op de arbeidsmarkt. Deze indicator geeft aan welke vraagaanbod-discrepantie er per opleidingstype te verwachten is. Een aanbodoverschot impliceert echter niet vanzelfsprekend dat de desbetreffende groep werkloos zal worden en een aanbodtekort betekent niet automatisch dat er sprake zal zijn van onvervulde vacatures.

In de praktijk blijkt dat schoolverlaters met een opleiding waarvoor het aanbod de vraag overtreft een verslechtering van hun positie ervaren, bijvoorbeeld doordat zij vaker beneden hun niveau moeten werken, een slechter contract krijgen, slechter beloond worden of vaker genoegen moeten nemen met part-time werk, terwijl men liever een full-time betrekking had ${ }^{15}$. In dat geval zullen werkgevers immers doorgaans hun eisen aanpassen en mensen aannemen met een hogere opleidingsachtergrond dan aanvankelijk gevraagd werd. Omgekeerd zal bij een tekortschietend aanbod de positie van schoolverlaters verbeteren. Deze nemen in dat geval geen genoegen met een functie op een lager niveau, een lagere beloning e.d.

Bij de opleidingstypen die door de opleidingen met een aanbodoverschot worden verdrongen, zal het aantal baanopeningen vanwege dit substitutieproces kleiner worden. Daarentegen zal er voor de opleidingen die verwant zijn aan de opleidingen met een tekortschietend aanbod juist sprake zijn van extra baanopeningen. Deze passieve substitie-effecten zijn derhalve van belang voor de arbeidsmarktperspectieven van de desbetreffende opleidingen.

De vraag-aanbod-confrontatie geeft eveneens voor elk opleidingstype een indicatie van de toekomstige kans op knelpunten in de personeelsvoorziening. Daarbij

15. M.H. Wieling en L. Borghans, Discrepancies between Demand and Supply and Adjustment Processes on the Labour Market. ROA-RM-1995/5E, Maastricht, 1995. 
bepalen de uitbreidings- en vervangingsvraag samen de recruteringsbehoefte per opleidingstype. Bij krimpende werkgelegenheid voor een bepaald opleidingstype wordt deze recruteringsbehoefte op een enigszins andere wijze berekend dan het aantal baanopeningen voor nieuwkomers op de arbeidsmarkt, omdat er vanuit het perspectief van de bedrijven immers de mogelijkheid bestaat om de krimp gedeeltelijk te realiseren door een verdere beperking van de instroom, waardoor de gedwongen uitstroom van het zittende personeel minder groot hoeft te zijn. Zeker wanneer bedrijven geconfronteerd worden met een krappe arbeidsmarkt voor een bepaald opleidingstype, zullen zij van deze mogelijkheid gebruik maken.

In dit hoofdstuk worden de verschillende vraag- en aanbodstromen besproken voor de beroepsklasse en opleidingstypen die relevant zijn voor de zorg- en welzijnssector. Daarbij wordt telkens een vergelijking gemaakt met de ontwikkeling voor de totale beroepsbevolking. Bovendien is de verwachte ontwikkelingen telkens voorzien van een kwalitatieve en relatieve typering, waarbij de resultaten voor de verschillende beroepsklassen en opleidingstypen ten opzichte van elkaar worden gepositioneerd. Deze typering maakt het mogelijk de relatieve omvang van de desbetreffende ontwikkeling snel te interpreteren, zonder al te veel gewicht te geven aan geringe verschillen tussen de exacte cijfers ${ }^{16}$.

Eerst zal voor zowel de maatschappelijk en cultureel werkers als de sociaalculturele en verzorgende opleidingstypen een beeld worden geschetst van de uitbreidingsvraag. Vervolgens wordt ingegaan op de verwachte vervangingsvraag naar beroepsklasse en opleidingstype. Daarna worden de prognoses van de arbeidsmarktinstroom van schoolverlaters gepresenteerd. Hierbij wordt logischerwijs alleen ingegaan op de prognoses per opleidingstype. Ten slotte wordt een overzicht gegeven van de verwachte arbeidsmarktperspectieven voor de voor deze sector relevante opleidingstypen. Hierbij komen ook indicaties voor de toekomstige kans op knelpunten in de personeelsvoorziening in de zorg- en welzijnssector aan bod. Bij de confrontatie tussen vraag en aanbod is ook rekening gehouden met het percentage kortdurig werklozen.

16. Met uitzondering van de indicator m.b.t. het arbeidsmarktperspectief zijn de meeste grenzen bepaald aan de hand van de symmetrische methode, waarbij op basis van het gemiddelde en de standaardafwijking van de betreffende variabele de beroepsklassen of opleidingstypen symmetrisch zijn verdeeld over de vijf typeringen erg laag, laag, gemiddeld, hoog, erg hoog. Daarnaast is in een aantal gevallen de kwantielenmethode gebruikt, waarbij de grenzen zodanig zijn bepaald dat $10 \%$ in de klasse erg laag valt, $20 \%$ in laag, $40 \%$ in gemiddeld, $20 \%$ in hoog en $10 \%$ in de klasse erg hoog. Zie voor de wijze waarop deze typeringen als ook de trendmatige ontwikkelingen zijn bepaald verder het werkdocument Methodiek van het informatiesysteem onderwijs-arbeidsmarkt 1995 (ROAW-1995/3). 


\subsection{Werkgelegenheidsontwikkeling}

De Nederlandse economie heeft vanaf 1994 een verdere versnelling van de groei laten zien. De economische opleving ging vorig jaar desondanks nog gepaard met een stagnerende werkgelegenheidsontwikkeling, maar dit jaar herstelt de werkgelegenheidsgroei zich over een breed front. Naar verwachting zal de groei na 1996 weer enigszins afzwakken. Uit de werkgelegenheidsramingen van het Centraal Planbureau (CPB) voor de sector kwartaire diensten blijkt dat de jaarlijkse werkgelegenheidsgroei voor deze sector op $2,0 \%$ wordt geschat voor de periode 1995-2000. Voor de totale beroepsbevolking is een jaarlijkse uitbreidingsvraag tot 2000 berekend van $0,8 \%$, hetgeen voor de totale periode $4 \%$ bedraagt. In de periode 1990-1994 betrof de werkgelegenheidsgroei voor de totale beroepsbevolking $1 \%$, terwijl deze voor de kwartaire diensten 1,4\% bedroeg.

Figuur $4.2 a$

Werkgelegenheidsontwikkeling 1995-2000, naar beroepsklasse

\section{werkgelegenheidsontwikkeling 1995-2000}

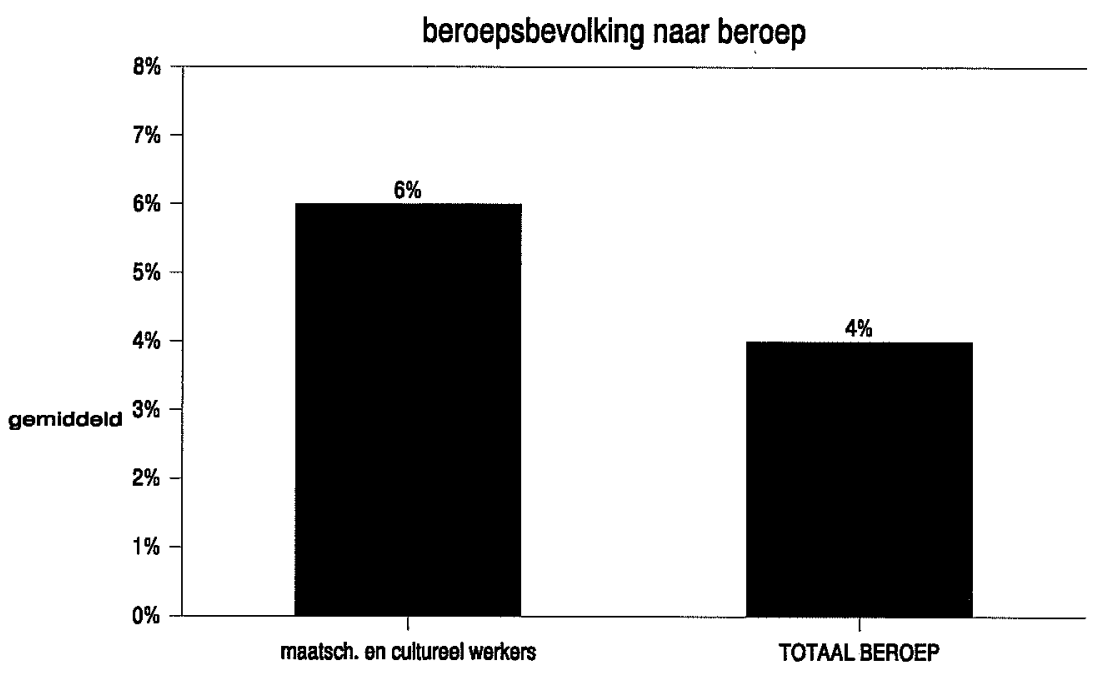

Bron: ROA

Echter, berekend voor de sociaal-culturele beroepen die voor een belangrijk deel in de kwartaire diensten werkzaam zijn (en waarvan de maatschappelijke en cultureel werkers een onderdeel uitmaken), was de werkgelegenheidsgroei met 3,0\% voor de periode 1990-1994 gunstiger dan voor de periode $1995-2000$ is voorspeld, namelijk $1,9 \%$. 
De verwachting hierbij is dat de schoolverlaters meer dan evenredig zullen profiteren van de voorspelde werkgelegenheidsgroei. Dit komt omdat de toename van het aanbod voor een belangrijk deel bestaat uit instroom van WAO'ers, herintreders en immigranten die doorgaans een zwakkere arbeidsmarktpositie hebben dan schoolverlaters.

Figuur 4.2a laat zien dat er tussen 1995 en 2000 voor de maatschappelijk en cultureel werkers een uitbreiding van de werkgelegenheid met zo'n $6 \%$ wordt verwacht. Op jaarbasis gaat het dan om een groei van $1,2 \%$ van de werkgelegenheid in deze beroepsklasse. In absolute aantallen betreft het een uitbreiding van 4.200 personen. Voor de totale beroepsbevolking wordt de uitbreidingsvraag op circa $4 \%$ geschat, hetgeen per jaar een uitbreiding van $0,8 \%$ betekent. De uitbreidingsvraag voor de maatschappelijk en cultureel werkers wordt getypeerd als gemiddeld.

Figuur $4.2 b$

Werkgelegenheidsontwikkeling 1995-2000, naar opleidingstype

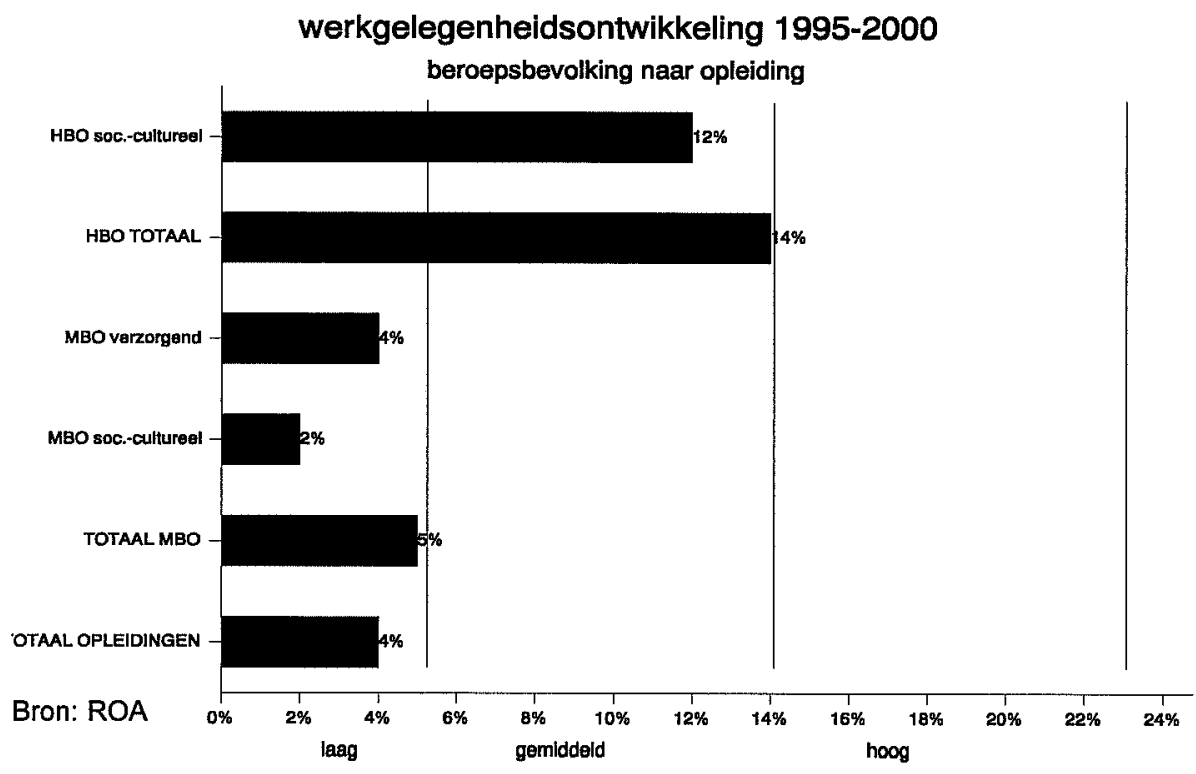

Wanneer de toekomstige werkgelegenheidsontwikkeling naar opleidingstype wordt berekend, kan men constateren dat de groei bij de sociaal-culturele en verzorgende beroepsopleidingen doorgaans (iets) lager is dan de uitbreidingsvraag die voor het totaal MBO en totaal HBO wordt verwacht. Zo is de uitbreidingsvraag bij het HBO sociaal-cultureel weliswaar drie keer zo hoog als die voor het MBO verzorgend en zes keer zo hoog als die voor het MBO sociaal-cultureel, maar in vergelijking met 
die voor het totale HBO is de uitbreidingsvraag voor het HBO sociaal-cultureel toch iets lager.

\subsection{Vervangingsvraag}

Ondanks de geringe werkgelegenheidsgroei bezien over de gehele vijfjaarsperiode, wordt toch voor de totale groep van schoolverlaters verwacht dat de arbeidsmarktperspectieven enigszins zullen verbeteren. Dit verbeterde perspectief kan vooral worden toegeschreven aan de demografische ontwikkeling, toenemende vergrijzing en ontgroening, waardoor de vervangingsbehoefte aantrekt en de arbeidsmarktinstroom van schoolverlaters in totaal licht zal afnemen.

Figuur 4.3a

Vervangingsvraag 1995-2000, naar beroepsklasse

\section{vervangingsvraag 1995-2000}

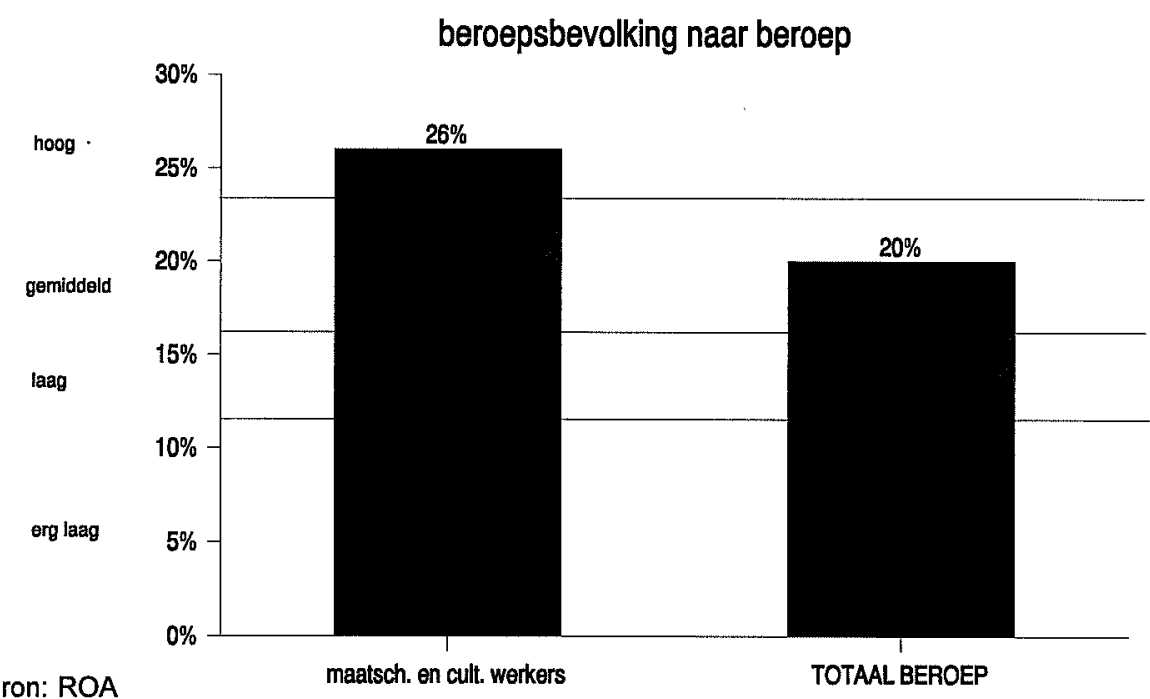

Was de totale uitstroom van de arbeidsmarkt in de eerste helft van de jaren negentig nog slechts 2,2\% op jaarbasis, voor de periode 1995-2000 wordt een gemiddelde jaarlijkse uitstroom van 3,3\% verwacht. Tussen 1995 en 2000 neemt de werkgelegenheid naar verwachting met een kwart miljoen werkenden toe, terwijl meer dan een miljoen werkenden de arbeidsmarkt vanwege pensionering, VUT, gezinstaken e.d. zullen verlaten. Macro-economisch gezien betekent dit dat $80 \%$ van alle baanopeningen ontstaat doordat vertrekkend personeel vervangen moet worden. Omdat voor een openvallende plaats echter niet altijd een nieuwkomer met dezelfde opleidingsachtergrond wordt gevraagd, leidt niet de volledige 
arbeidsmarktuitstroom tot vervangingsvraag, maar gedeeltelijk ook tot uitbreidingsvraag naar andere opleidingstypen.

Uit figuur 4.3a blijkt dat de vervangingsvraag voor de maatschappelijk en cultureel werkers met $26 \%$ voor de totale prognoseperiode en $4,7 \%$ op jaarbasis hoog genoemd kan worden. Voor de totale beroepsbevolking bedraagt de vervangingsvraag tussen $1995-2000$ namelijk $20 \%$.

Omgerekend naar absolute aantallen betekent dit dat 17.900 mensen als maatschappelijk en cultureel werker in de prognoseperiode aan de slag kunnen als gevolg van vervanging van vertrekkend personeel.

Wanneer de vervangingsbehoefte naar opleidingstype in kaart wordt gebracht, blijken er in de vervangingsvraag tussen 1995-2000 tussen de onderscheiden MBOen HBO-opleidingen nauwelijks verschillen te bestaan. Deze varieert van $12 \%$ voor MBO sociaal-cultureel, dat net als laag wordt getypeerd, tot $16 \%$ voor HBO sociaalcultureel, hetgeen een gemiddelde vervangingsvraag wordt genoemd.

Figuur 4.3b

Vervangingsvraag 1995-2000, naar opleidingstype

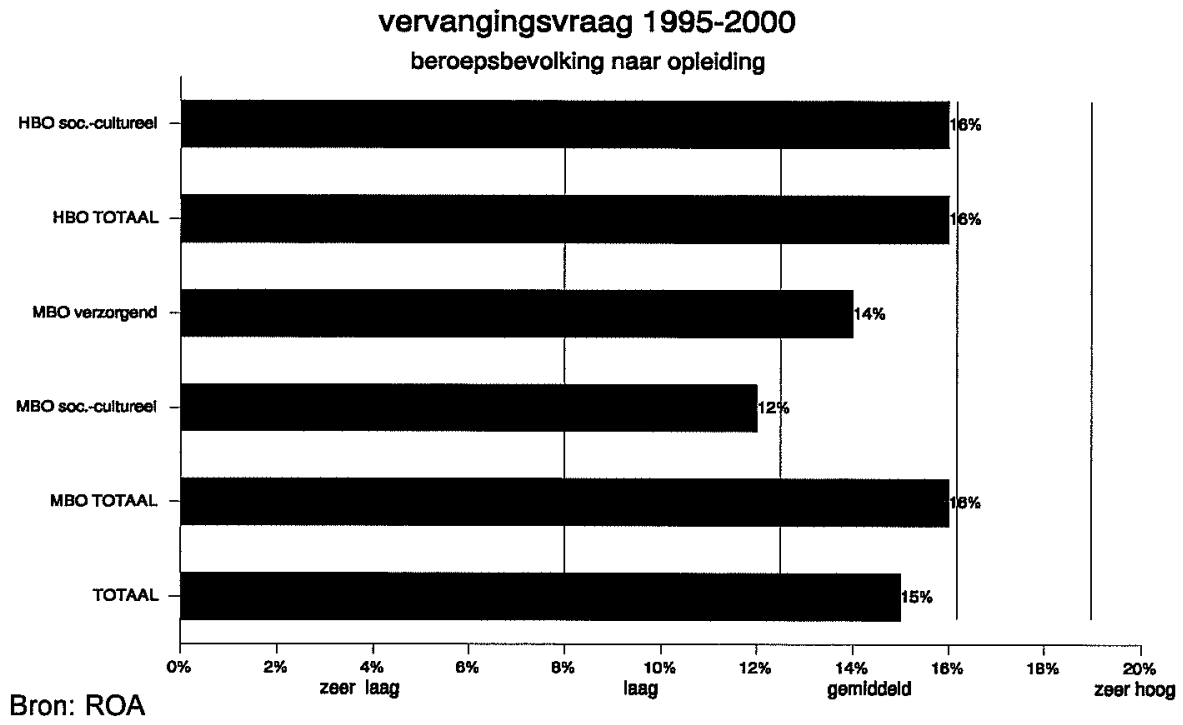




\subsection{Baanopeningen}

Het totaal aantal baanopeningen voor nieuwkomers op de arbeidsmarkt bestaat uit de som van de uitbreidingsvraag en de vervangingsvraag. Het hoeft overigens niet zo te zijn dat beroepsklassen en opleidingstypen waarvoor het aantal baanopeningen groot is, per definitie ook een grote recruteringsbehoefte met zich meebrengen. Het komt namelijk nogal eens voor dat de werkgevers de opengevallen plaatsen niet wensen op te vullen.

Hoewel de vervangingsvraag getalsmatig de grootste component vormt, zijn de verschillen tussen de beroepsklassen en opleidingstypen doorgaans groter bij de uitbreidingsvraag. De uitbreidingsvraag bepaalt daardoor in hoge mate de relatieve uitschieters wat betreft het aantal baanopeningen.

Bij de maatschappelijk en cultureel werkers is het percentage baanopeningen $8 \%$ hoger dan voor de totale beroepsbevolking voor de vijjarige prognoseperiode is bepaald ( $32 \%$ versus $24 \%$ ). Het aantal baanopeningen voor nieuwkomers op de arbeidsmarkt kan voor de maatschappelijk en cultureel werkers dus relatief hoog worden genoemd. Op jaarbasis gaat het bij deze beroepsklasse om 5,9\% en uitgedrukt in absolute aantallen betreft het 22.100 baanopeningen voor maatschappelijk en cultureel werkers tussen 1995 en 2000. Het aandeel van de uitbreidingsvraag in het totaal aantal baanopeningen betreft voor deze beroepsklasse $19 \%$.

Onderverdeeld naar opleidingstype blijkt het aantal baanopeningen voor de sociaalculturele en verzorgende opleidingen (iets) lager dan voor het totale MBO en HBO geldt. Met name het relatieve aantal baanopeningen bij MBO sociaal-cultureel kan met $13 \%$ voor de totale prognoseperiode (en $2,6 \%$ op jaarbasis) laag worden genoemd. In absolute aantallen betreft dit voor de gehele periode zo'n 7.500 personen. Voor het MBO verzorgend worden tussen 1995 en 200040.600 baanopeningen verwacht, in relatieve cijfers uitgedrukt is dat $18 \%$ voor de gehele periode en $3,5 \%$ op jaarbasis. Bij het HBO sociaal-cultureel gaat het om 32.400 baanopeningen, hetgeen voor de totale prognoseperiode relatief $28 \%$ is, en jaarlijks een groei van $5,3 \%$ betekent. Voorts kan men in figuur $4.4 \mathrm{~b}$ aflezen dat bij het $\mathrm{HBO}$ (inclusief $\mathrm{HBO}$ sociaal-cultureel) het aandeel van de uitbreidingsvraag in het totaal aantal baanopeningen naar verhouding hoog is. 
Figuur $4.4 a$

Baanopeningen voor nieuwkomers 1995-2000, naar beroepsklasse

\section{baanopeningen 1995-2000}

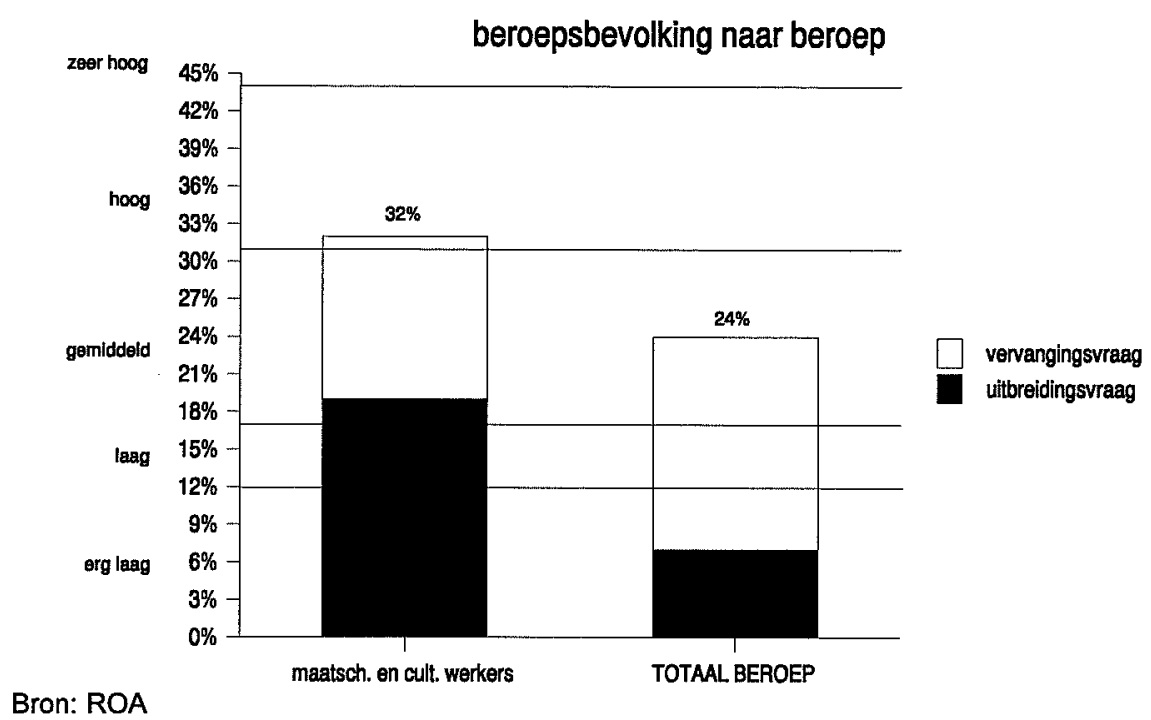

Figuur 4.4b

Baanopeningen voor nieuwkomers 1995-2000, naar opleidingstype baanopeningen 1995-2000

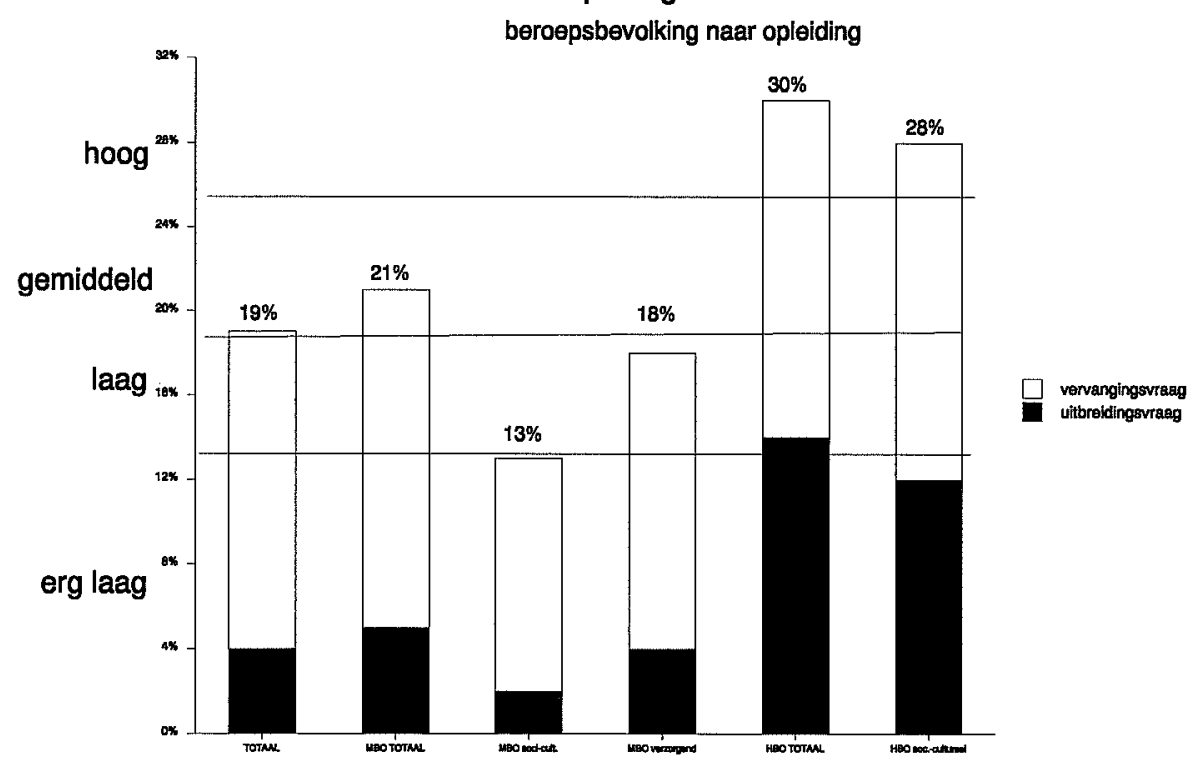

Bron: ROA 


\subsection{Instroom van schoolverlaters}

Tot nu toe is in dit hoofdstuk slechts ingegaan op de toekomstige vraagontwikkeling op de arbeidsmarkt. Tegenover de ontwikkeling van de uitbreidings- en vervangingsvraag, staan echter de ontwikkelingen aan de aanbodzijde van de arbeidsmarkt. In deze paragraaf wordt daarom ingegaan op de instroom van schoolverlaters op de arbeidsmarkt. Zoals reeds in hoofdstuk 2 is aangegeven gaat het hier om dat deel van de schoolverlaters dat daadwerkelijk tot de arbeidsmarkt toetreedt (als werkende of als werkzoekende). Bij het berekenen van het uiteindelijke arbeidsmarktperspectief wordt ook rekening gehouden met het percentage kortdurig werklozen aan het begin van de prognoseperiode, aangezien deze aanbodcomponent concurreert met de schoolverlaters bij het verwerven van een baan.

\section{Figuur 4.5}

Instroom schoolverlaters 1995-2000, naar opleidingstype instroom schoolverlaters 1995-2000

beroepsbevolking naar opleiding

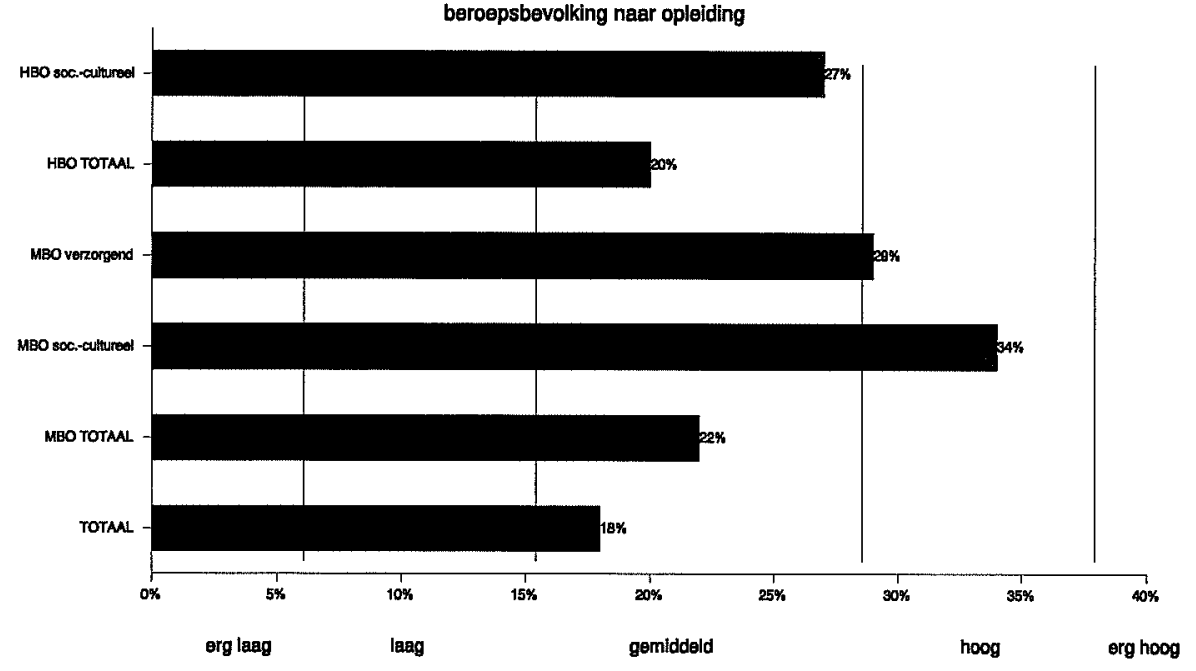

Bron: ROA

In vergelijking met de arbeidsmarktinstroom vanuit het totale onderwijs en het MBO en $\mathrm{HBO}$, is de instroom van schoolverlaters vanuit de sociaal-culturele en verzorgende beroepsopleidingen relatief hoog. Voor HBO sociaal-cultureel wordt de arbeidsmarktinstroom met $27 \%$ voor de totale prognoseperiode (en $4,9 \%$ op jaarbasis) weliswaar net als gemiddeld getypeerd, maar deze ligt toch beduidend hoger dan voor de andere HBO-opleidingen. Vanuit het HBO sociaal-cultureel gaat het om een instroom van 31.400 personen. Bij het MBO sociaal-cultureel is de 
instroom met $34 \%(6,0 \%$ op jaarbasis) hoog en het betreft 18.900 schoolverlaters. Voor MBO verzorgend wordt een relatieve instroom van $29 \%$, eveneens hoog, verwacht, hetgeen op jaarbasis $5,2 \%$ betekent en in absolute aantallen 62.700 instromers voor de gehele prognoseperiode.

\subsection{Toekomstig arbeidsmarktperspectief}

Op basis van de voorgaande prognoses over de vraag- en aanbodontwikkelingen op de arbeidsmarkt, kan een indicatie worden gegeven van de verwachte toekomstige arbeidsmarktperspectieven. Het berekende arbeidsmarktperspectief geeft de verhouding weer tussen het voor de schoolverlaters relevante aanbod (van andere schoolverlaters en kortdurig werklozen) en de daar tegenoverstaande vraag per opleidingstype. Deze indicator voor het toekomstige arbeidsmarktperspectief wordt getypeerd naar vier klassen. Als het aanbod kleiner is dan de vraag, en de indicator kleiner is dan 1,00, wordt het perspectief als goed getypeerd. Als de indicator tussen de 1,00 en 1,05 ligt en het aanbodoverschot derhalve niet groter is dan wat als frictie kan worden aangemerkt, wordt het perspectief als redelijk aangeduid. Tussen de 1,05 en 1,15 betreft het een matig perspectief, terwijl een indicator met een waarde groter dan 1,15 een slecht arbeidsmarktperspectief aanduidt.

De relatief weinig baanopeningen in combinatie met een relatief hoge arbeidsmarktinstroom van schoolverlaters levert voor schoolverlaters van MBO sociaal-cultureel een slecht arbeidsmarktperspectief op voor de middellange termijn. Daarentegen zijn de vraag- en aanbodontwikkelingen bij het $\mathrm{HBO}$ sociaal-cultureel beter in balans, zodat het arbeidsmarktperspectief voor hen goed kan worden genoemd. De schoolverlaters van het MBO verzorgend wacht een matig perspectief. Ook bij hen is de arbeidsmarktinstroom vanuit de opleiding te groot in vergelijking met het aantal baanopeningen, dat als gemiddeld kan worden getypeerd.

Als een bepaalde opleiding een goed arbeidsmarktperspectief heeft, dan zal het voor de schoolverlaters van deze opleiding relatief gemakkelijk zijn om een baan te vinden. Daarentegen is het dan voor werkgevers juist moeilijk om dergelijke schoolverlaters te werven. Een goed arbeidsmarktperspectief voor schoolverlaters betekent dus een grote kans op knelpunten in de personeelsvoorziening voor werkgevers. Echter, het omgekeerde is niet altijd het geval. Bij een krimpende werkgelegenheid zullen bedrijven immers de mogelijkheid aangrijpen om gedwongen uitstroom van het zittende personeel zoveel mogelijk te vermijden door de instroom van nieuwkomers nog drastischer te beperken. 
Figuur 4.6

Toekomstig arbeidsmarktperspectief 1995-2000, naar opleidingstype

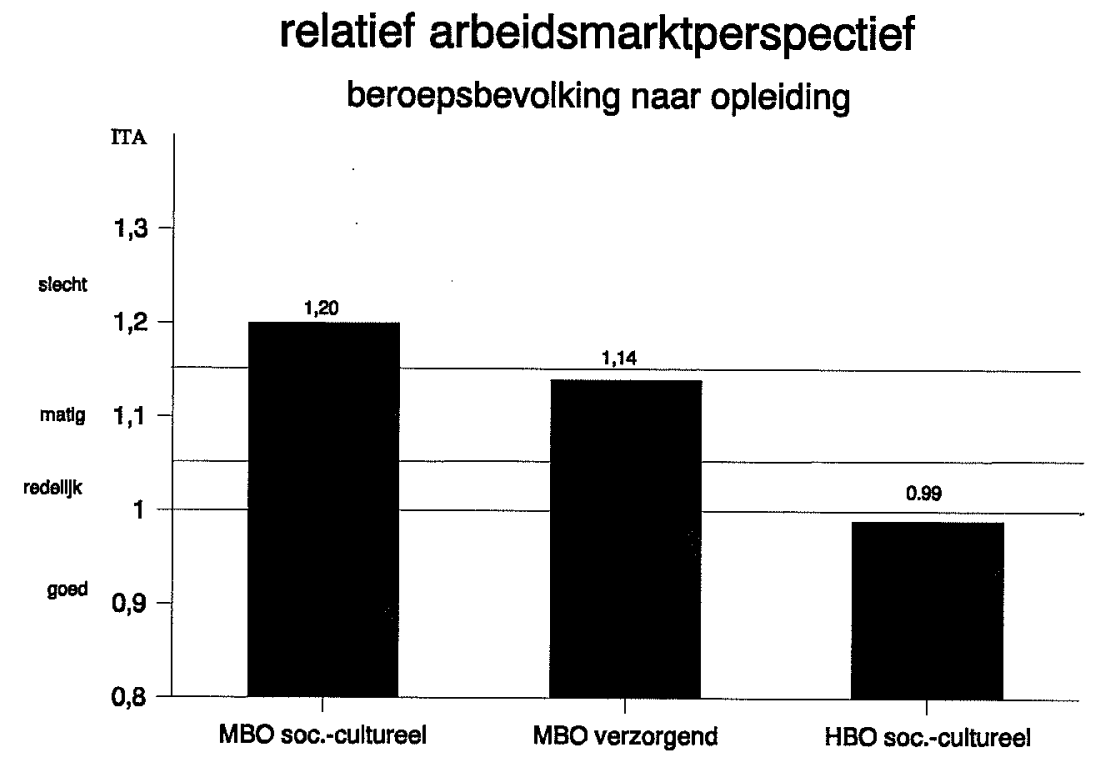

Bron: ROA

Wat betreft de sociaal-culturele en verzorgende beroepsopleidingen kan worden opgemerkt, dat de kans op knelpunten in de personeelsvoorziening alleen redelijk groot wordt geacht voor het invullen van banen waarvoor een opleiding uit het cluster HBO sociaal-cultureel wordt gevraagd. De kans dat deze knelpunten zich ook zullen voordien bij de clusters MBO verzorging en sociaal-cultureel wordt zeer klein ingeschat. De afgestudeerden van de middelbare sociaal-culturele en verzorgende opleidingen doen er wellicht goed aan om na de MBO-opleiding de studie op HBO-niveau te vervolgen. Dit is niet alleen gunstig voor de betreffende schoolverlaters, maar kan eveneens de verwachte knelpunten in de personeelsvoorziening van schoolverlaters met een sociaal-culturele opleidingsachtergrond op HBOniveau beperken.

Echter, hierbij dient men wel te bedenken, dat een vervolgopleiding in het HBO niet de garantie geeft dat na deze opleiding de functies waarin men dan daarna terecht komt op een aanzienlijk hoger functieniveau zullen liggen. Zoals in het voorgaande hoofdstuk reeds geconstateerd, komen met name de afgestudeerden van de sociaal-agogische HBO-opleidingen nogal eens terecht op functies op MBO-niveau. Dit verdringingsproces van middelbaar opgeleiden door hoger geschoolden, dat deels de relatief goede kansen op werk voor hoger geschoolden verklaart, kan leiden tot onderbenutting van kwalificaties van deze hoger geschoolden. 


\section{Conclusies en aanbevelingen}

\subsection{Conclusies arbeidsmarkt zorg- en welzijnssector}

In deze paragraaf worden de belangrijkste bevindingen over de actuele en toekomstige arbeidmarktsituatie in de zorg- en welzijnssector samengevat. Voor een overzicht van de belangrijkste kerncijfers voor de beroepsbeoefenaren in deze sector wordt $u$ verwezen naar bijlage 2 . In deze paragraaf wordt voor de maatschappelijk en cultureel werkers en de beroepsbeoefenaren die een middelbare of hogere sociaal-culturele of verzorgende beroepsopleiding hebben genoten, de belangrijkste arbeidsmarktkenmerken en de (toekomstige) ontwikkelingen daarin beschreven. De beroepsbeoefenaren die in het domein van de sociaal-pedagogisch werkers werkzaam zijn, vormen een belangrijk onderdeel van de maatschappelijk en cultureel werkers (zie paragraaf 3.1.1). Ook de actuele arbeidsmarktpositie van de schoolverlaters van de voor deze sector relevante agogische en verzorgende beroepsopleidingen wordt in deze paragraaf samengevat.

\section{Actuele arbeidsmarktpositie}

De beroepsgroep van maatschappelijk en cultureel werkers vormt met bijna 70.000 werkenden ruim $1 \%$ van de totale werkzame beroepsbevolking in Nederland. Het aandeel van deze beroepsklasse in de totale Nederlandse werkgelegenheid neemt bovendien toe. Het aantal beroepsbeoefenaren met een sociaal-culturele of verzorgende opleiding is overigens veel groter: 52.500 werkenden met een MBO sociaal-culturele opleiding, 212.500 werkenden met een MBO verzorgende opleiding en 118.000 met een HBO sociaal-culturele opleiding.

Er is namelijk geen sprake van een 1-op-1-relatie tussen opleiding, (sector en) beroep. Net als in andere beroepen komen in de beroepsklasse van maatschappelijk en cultureel werkers beroepsbeoefenaren met diverse opleidingsachtergronden terecht. Hoewel bijna tweederde van de maatschappelijk en cultureel werkers een sociaal-culturele opleidingsachtergrond heeft op MBO-, $\mathrm{HBO}$ - of WO-niveau, hebben de anderen een andere opleidingsachtergrond, zoals een verzorgende of verpleegkundige (zie paragraaf 3.1 .5 en bijlage 2).

Omgekeerd is een deel van degenen die een sociaal-culturele of verzorgende MBOof HBO-opleiding hebben genoten, in andere beroepen werkzaam dan die van de maatschappelijk of cultureel werkers. Een deel is zelfs buiten de sector zorg- en welzijn werkzaam. Dit kan na verloop van tijd in de verdere beroepsloopbaan zijn gebeurd, maar eveneens aan het begin van de beroepsloopbaan. Overigens laten 
de resultaten voor de schoolverlaters van sociaal-agogische opleidingen zien dat ook starters op de arbeidsmarkt in een brede waaier van sociaal-culturele of verzorgende beroepen terecht komen (zie paragraaf 3.1.1 en 3.2.5). De uitwijkmogelijkheden voor de sociaal-cultureel of verzorgend opgeleiden zijn, in vergelijking met die voor de totale beroepsbevolking gemiddeld te noemen, hoewel deze voor de starters op de arbeidsmarkt lager zijn dan voor degenen die verder in de loopbaan zijn.

Ondanks deze overlap in de beroepssegmenten, kan voor de sociaal-culturele en verzorgende beroepsopleidingen wel een eigen beroepsprofiel worden waargenomen. Echter het gaat hier niet om uitsluitend complementaire beroependomeinen. Binnen de beroependomeinen is wel degelijk sprake van concurrentie tussen de verschillende sociaal-culturele en verzorgende beroepsopleidingen. Deze concurrentie geldt niet alleen voor diverse opleidingsrichtingen binnen één niveau, maar vindt men eveneens terug tussen de afgestudeerden van de opeenlopende opleidingsniveaus (zie paragraaf 3.2.5).

De werkgelegenheid voor de maatschappelijk en cultureel werkers en de beroepsbeoefenaren met een sociaal-culturele of verzorgende opleidingsachtergrond is overigens nauwelijks gevoelig voor conjunctuurschommelingen. $\mathrm{Er}$ is sprake van een relatief stabiele werkgelegenheidssituatie voor maatschappelijk en cultureel werkers. De werkgelegenheid voor beroepsbeoefenaren die in zeer 'smalle' beroepssegmenten werkzaam zijn, is doorgaans conjunctuurgevoeliger, hetgeen het risico van 'varkenscycli' op de arbeidsmarkt met zich meebrengt.

Het arbeidsmarktsegment waarin de maatschappelijk en cultureel werkers werkzaam zijn kenmerkt zich verder door een relatief hoog percentage vrouwen ( $67 \%$ versus $37 \%$ voor de totale beroepsbevolking). Dit geldt in versterkte mate voor degenen die met een verzorgende MBO-opleiding op de arbeidsmarkt werkzaam zijn, waarbij maar liefst $81 \%$ van de beroepsbeoefenaren uit vrouwen bestaat. In de toekomst zal het hoge aandeel van vrouwen in deze sociaal-culturele en verzorgende opleidings- (en dus) beroepssegmenten hoogstwaarschijnlijk niet (sterk) afnemen. Ruim driekwart tot bijna $100 \%$ van de huidige schoolverlaters uit sociaal-agogische beroepsopleidingen blijkt namelijk vrouw te zijn, terwijl in de totale schoolverlaterspopulatie op MBO- en HBO-niveau vrouwen slechts licht in de meerderheid zijn.

Hiermee samenhangend kenmerkt dit arbeidsmarktsegment zich verder door een hoog aandeel deeltijd-werkers. Van de maatschappelijk en cultureel werkers werkt ruim twee maal zoveel beroepsbeoefenaren in deeltijd dan gemiddeld voor de totale beroepsbevolking het geval is ( $57 \%$ versus $25 \%$ ). Uit nadere analyses blijkt dat het hier deels om een sexe-effect gaat en deels om een sector-/beroepseffect. 
Ten slotte blijkt uit de resultaten dat het aandeel jongeren (tot 30 jaar) in de beroepsklasse van maatschappelijk en cultureel werkers met $16 \%$ laag is te noemen. Voor de totale werkende beroepsbevolking geldt een percentage van $30 \%$. Dit fenomeen hangt samen met het feit dat voor het uitoefenen van een beroep als maatschappelijk of cultureel werker doorgaans op $z^{\prime} n$ minst een middelbare beroepsopleiding nodig is. Van de maatschappelijk en cultureel werkers heeft ruim een kwart (27\%) een MBO-opleiding genoten, ruim de helft $(52 \%)$ een HBOopleiding en is zelfs $14 \%$ academisch geschoold. Voor de totale beroepsbevolking geldt een volgend opleidingsprofiel: WO: $7 \%$; HBO: $17 \%$; $\mathrm{MBO}$ : $39 \%$ en overige opleidingsniveaus: $37 \%$. De maatschappelijk en cultureel werkers zijn gemiddeld dus hoger geschoold in vergelijking met alle werkenden tezamen.

\section{Toekomstig arbeidsmarktperspectief}

Uit de prognoses blijkt dat in de periode 1995-2000 het percentage baanopeningen voor de maatschappelijk en cultureel werkers met $32 \%$ relatief hoog is. Voor de totale beroepsbevolking is namelijk een percentage van $24 \%$ baanopeningen berekend. Een belangrijk deel van deze baanopeningen (81\%) bij de maatschappelijk en cultureel werkers ontstaat als gevolg van een vervanging van bestaand personeel dat vanwege pensionering, arbeidsongeschiktheid of opvoedingstaken (tijdelijk en/of deels) de arbeidsmarkt verlaat. Verder komt vervangingsvraag binnen de klasse van maatschappelijk en cultureel werkers tot stand doordat werknemers een ander soort functie gaan uitoefenen. Slechts $19 \%$ van het totaal aantal baanopeningen voor de maatschappelijk en cultureel werkers is het resultaat van een verruiming van de werkgelegenheid, gemeten in personen (de uitbreidingsvraag kan dus ook het gevolg zijn van een verdergaande arbeidstijdverkorting). In vergelijking met het gemiddelde percentage van $4 \%$ voor de totale beroepsbevolking wordt de uitbreidingsvraag voor de maatschappelijk en cultureel werkers gemiddeld genoemd.

Het relatief hoge percentage baanopeningen voor de maatschappelijk en cultureel werkers vertaalt zich niet direct in een goed arbeidsmarktperspectief voor degenen die met een sociaal-culturele of verzorgende beroepsopleiding op de arbeidsmarkt komen, zo blijkt uit de resultaten van het informatiesysteem onderwijs-arbeidsmarkt.

In de eerste plaats is de werkgelegenheidsontwikkeling in de andere segmenten waarop deze 'nieuwkomers' terecht komen minder gunstig dan voor de maatschappelijk en cultureel werkers. Bovendien zijn in de prognoses voor de uitbreidingsvraag en vervangingsvraag ook de zogenaamde verdringingseffecten verdisconteerd. Met name de sociaal-culturele beroepsopleidingen, die op verschillende niveau's voorkomen, concurreren met elkaar in het beroepssegment van de maatschappelijk en cultureel werkers. De middelbaar (en lager) opgeleiden 
lukt het dan in geringere mate een baan in het eigen beroepssegment te verwerven. De hoger geschoolden verdringen hen hieruit, waarbij deze hoger opgeleiden wel het risico lopen onderbenut te worden in hun kwalificaties. Zeker als het hen niet lukt om - na enige jaren - door te stromen naar (sociaal-culturele) beroepen op een hoger functieniveau, zoals coördinator, stafmedewerker, unithoofd e.d.

Tot slot is juist bij de sociaal-culturele en verzorgende MBO-opleidingen de instroom van schoolverlaters op de arbeidsmarkt naar verhouding hoog te noemen. Voor de sociaal-culturele HBO-opleidingen wordt daarentegen een gemiddelde instroom op de arbeidsmarkt verwacht.

In combinatie met het (erg) lage percentage baanopeningen voor de sociaalculturele en verzorgende MBO-opleidingen levert dit voor MBO sociaal-cultureel uiteindelijk een slecht arbeidsmarktperspectief voor de periode 1995-2000 op, en voor het MBO verzorgend een matig perspectief. Door een hoog percentage baanopeningen, als gevolg van een relatief hoge vervangingsvraag, en een gemiddeld percentage instromers op de arbeidsmarkt, wordt daarentegen een goed arbeidsmarktperspectief verwacht voor de afgestudeerden van de sociaal-culturele HBO-opleidingen.

\subsection{Mogelijkheden voor arbeidsmarktinformatiesysteem zorg- en welzijn}

\section{Discrepanties benodigde en beschikbare arbeidsmarktinformatie}

In de twee hieraan voorafgaande hoofdstukken is een overzicht gepresenteerd van de ontwikkelingen in de in-, door- en uitstroom op de arbeidsmarkt van de zorg- en welzijnssector aan de hand van een groot aantal kengetallen en indicatoren over de actuele en toekomstige arbeidsmarktsituatie in deze sector. Steeds is hierbij een vergelijking gemaakt tussen de resultaten voor de sociaal-agogische beroepen en opleidingen en voor de totale beroepsbevolking of voor het totaal wat betreft de schoolverlaters. Zowel kwantitatieve als kwalitatieve aansluitingsvraagstukken zijn aan de orde gesteld. De gepresenteerde resultaten zijn gebaseerd op gegevens uit het stroommodel van het informatiesysteem onderwijs-arbeidsmarkt van het ROA, en de grootschalige schoolverlatersonderzoeken die het ROA al een aantal jaren zelf uitvoert. In dit pilot-onderzoek zijn verder gegevens opgenomen uit een (tot op heden eenmalig uitgevoerd) panelonderzoek onder werkgevers in de zorg- en welzijnssector in Noord-Nederland.

Op voorhand was reeds bekend dat de in dit informatiesysteem en schoolverlatersonderzoeken opgenomen informatie niet geheel aan de informatiebehoefte van het Platform Kwalificatiebeleid Zorg en Welzijn kon voldoen. Vandaar dat in paragraaf 2.3 van dit pilot-onderzoek al in het kort is aangegeven in 
welke opzichten het huidige datamateriaal niet overeenkomt met de informatiebehoefte van het platform kwalificatiebeleid. Wanneer de tot op heden (bij het ROA) beschikbare gegevens worden vergeleken met de hierboven geschetste informatiebehoefte van het platform, blijkt dat er weliswaar veel informatie over de arbeidsmarktsituatie in de zorg en welzijnssector voor handen is, maar bij elkaar een soort 'lappendeken' vormt. De crux zit hem in de juiste combinatie van gehanteerde definties en classificaties, de afgebakende populatie, het eenmalige of periodieke karakter van het onderzoek, de inhoud van de kengetallen, het verschil in actuele indicatoren en prognoses, en 'last but not least' het gehanteerde aggregatieniveau.

De afgelopen jaren zijn er daarnaast, onder andere door het ROA, de nodige arbeidsmarktonderzoeken uitgevoerd, specifiek voor de zorg- en/of welzijnssector. Voor deze, in arbeidsmarktonderzoek vaak deels overlappende, sectoren is er weliswaar een schat aan informatie voor handen, doch deze is gefragmenteerd, alsmede onderling en in de tijd moeilijk vergelijkbaar (zie ook de resultaten van het Haalbaarheidsonderzoek naar de mogelijkheden van het gebruik van simulatiemodellen voor de arbeidsmarkt in de zorgsector, Van der Windt, 1995 en de Proefrapportage Arbeidsmarkt Zorgsector, Beekmans, 1994).

\section{Stroommodel arbeidsmarkt zorg- en welzijnssector: "van grof naar fijn"}

In hoofdstuk 2 is reeds aangegeven, dat de meest volledige (en overzichtelijke) beschrijving van de actuele en toekomstige arbeidsmarktsituatie verkregen wordt aan de hand van een zogenaamd 'stroommodel' van de in-, door- en uitstroom op de arbeidsmarkt in de zorg- en welzijnssector. In een dergelijk stroommodel worden niet alleen de 'standcijfers' over de werkzame en werkloze beroepsbevolking op een bepaald moment in kaart gebracht, maar worden ook de arbeidsmarktontwikkelingen weergegeven voor de onderscheiden periode. Ook het door het ROA gehanteerde informatiesysteem onderwijs-arbeidsmarkt betreft een dergelijk stroommodel (zie ook figuur 4.1).

Verder dient een arbeidsmarktmodel voor de zorg- en welzijnssector (idealiter) ook de volgende informatiekenmerken te bevatten:

- beleidsmatige informatie voor kwalificatiebeleid in brede zin;

- kwantitatieve en kwalitatieve informatie over actuele en toekomstige arbeidsmarktstromen aan vraag- en aanbodzijde (zie hoofdstuk 3 en 4);

- indelingen w.b. zorg en welzijnssector sluiten aan op sectorafbakening volgens CAO's en de door het platform gehanteerde vijf beroependomeinen, waarbij sociaal-pedagogisch werkers afzonderlijk zijn te onderscheiden;

- informatie representatief voor gehele Nederlandse (werkende) beroepsbevolking; 
- informatie gebaseerd op bestaande, actuele en jaarlijkse/periodieke gegevensbronnen, waarbij interne en externe vergelijkbaarheid is gewaarborgd;

- heldere en duidelijke presentatie gegevens.

De hierboven geschetste discrepantie tussen beschikbare en voor de sector bruikbare arbeidsmarktinformatie heeft niet alleen bij het platform maar ook bij andere betrokkenen bij dergelijke onderzoeken, zoals het Ministerie van Volksgezondheid Welzijn en Sport (WWS), sociale partners en koepelorganisaties als het NIZW, alsmede bij de uitvoerende onderzoeksinstellingen, de vraag opgeworpen of het niet beter zou zijn dit arbeidsmarktonderzoek te gaan stroomlijnen. Dit om een helder en éénduidig overzicht te verkrijgen in de huidige en toekomstige arbeidsmarktontwikkelingen in de sector zorg en welzijn in brede zin. Inmiddels is daarom de Organisatie voor Strategisch Arbeidsmarktonderzoek (OSA) aangesteld als coördinator van het arbeidsmarktonderzoek in de (gezondheids)zorgsector. In opdracht van het Ministerie van WWS is met de uitvoering van een vierjarig onderzoeksprogramma Arbeidsmarkt Zorgsector gestart. Een belangrijke prioriteit binnen dit programma is de ontwikkeling van een zogenaamd stroommodel, vergelijkbaar met het ROA-informatiesysteem onderwijsarbeidsmarkt, om beter inzicht te krijgen in de stromen aan de vraag- en aanbodzijde van de arbeidsmarkt in deze zorgsector. Hierbij wordt gestreefd naar een vergaande verfijning van de indelingen naar sector, beroepscategorie en regio. Het model richt zich vooralsnog op de verplegende en verzorgende beroepen in de (gezondheids)zorg. Bij het vooronderzoek naar de mogelijkheden voor het opzetten van dit stroommodel voor de (intramurale) gezondheidszorg, is men tot de conclusie gekomen dat de gegevens die door de Bedrijfsvereniging voor de Gezondheid, Geestelijke en Maatschappelijke Belangen (BVG) worden verzameld het best bruikbaar zijn als 'data-input' voor een dergelijk stroommodel (zie Vermeulen e.a., 1995). In 1996 wordt verslag gedaan van de wijze waarop de 'vulling' van de BVGgegevens in het stroommodel van de (intramurale) zorgsector voor de verpleegkundige en verzorgende beroepen is verlopen.

Een stroommodel voor het in kaart brengen van de arbeidsmarktontwikkelingen in de zorg- en welzijnssector wordt in de eerste plaats gevoed door periodieke (jaarlijkse) matrices van aantallen beroepsbeoefenaren onderverdeeld naar de sector èn het beroep waarin men werkzaam is, alsmede de hoogst genoten opleiding. Door een vergelijking van de aantallen in de betreffende cellen van sector * beroep * opleiding in de tijd komt men de netto in-, door- en uitstroom op het spoor. In figuur 5.1 wordt een dergelijke matrix voor één jaar gepresenteerd. De matrix betreft alleen de werkende beroepsbevolking. Instroom van nieuwkomers of herintreders op de arbeidsmarkt en uitstroom als gevolg van pensionering, VUT, arbeidsongeschiktheid en zorgverlof is niet expliciet in deze schets weergegeven 
(het netto-effect van in-/uitstroom is overigens te bepalen bij vergelijking van matrices op meerdere momenten).

Figuur 5.1

Datamatrix stroommodel arbeidsmarkt zorg- en welzijnssector

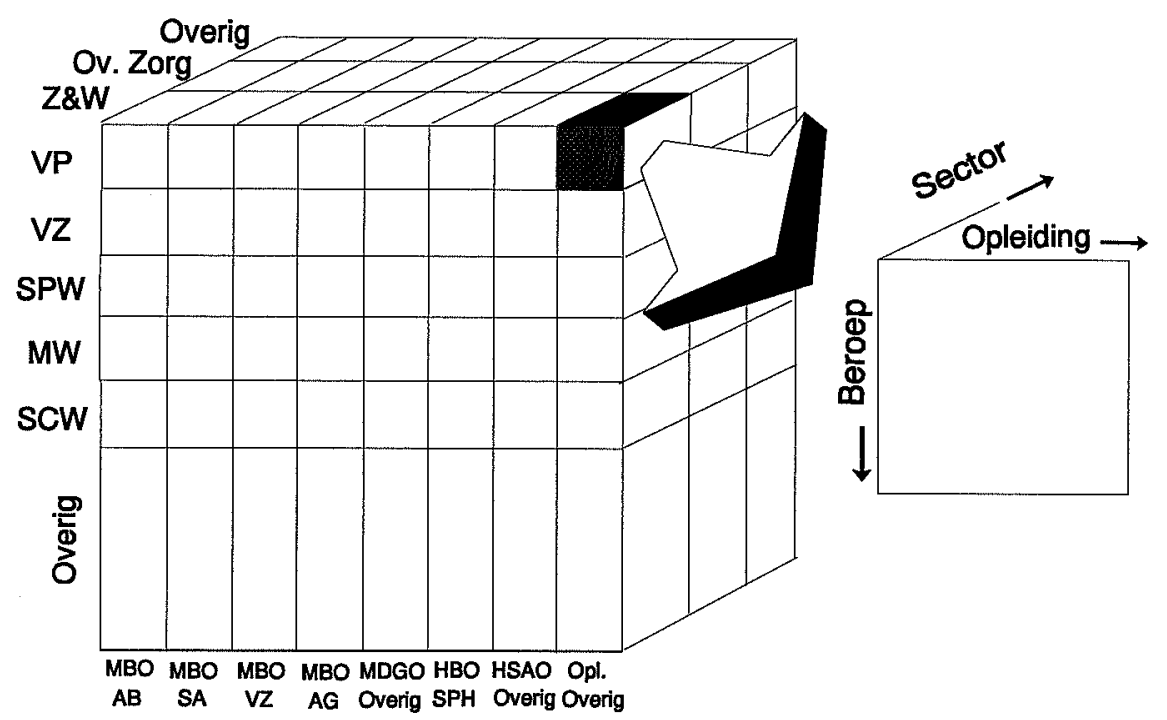

Voor de zorg- en welzijnssector zouden in principe de volgende beroeps- en opleidingscategorieën onderscheiden kunnen worden (zie figuur 5.1).

Wat betreft de beroepscategorieën betreft het de volgende domeinen:

- verpleging (VP);

- verzorging (VZ);

- sociaal-pedagogisch werk (SPW);

- maatschappelijk werk en dienstverlening (MW);

- sociaal-cultureel werk (SCW).

Bij de opleidingen zijn met name de volgende categorieën relevant:

- MDGO activiteitenbegeleiding (MBO AB);

- MDGO sociale arbeid (MBO SA);

- MDGO verzorging (MBO VZ);

- MDGO agogisch werk (MBO AG);

- overige MDGO-opleidingen;

- HSAO sociaal-pedagogische hulpverlening (HBO SPH);

- overige HSAO-opleidingen. 
Het arbeidsmarktmodel voor de zorg- en welzijnssector zou niet alleen de voor deze sector relevante sectoren, beroeps- en opleidingscategorieën moeten omvatten. Deze categorieën dienen te worden verbreed naar de totale arbeidsmarkt om dat alleen dan de volledige in-, door- en uitstroom ten aanzien van de zorg- en welzijnssector en sociaal-agogische beroepen in kaart is te brengen. De overige sectoren en beroeps-/opleidingscategorieën kunnen echter wel op een hoger aggregatieniveau worden ingedeeld dan voor de zorg- en welzijnssector zelf het geval is.

De systematiek en de bepaling van de arbeidsmarktindicatoren zoals gehanteerd in het ROA-informatiesysteem sluiten op zichzelf goed aan bij de voor de zorg- en welzijnssector relevante thema's binnen het arbeidsmarktvraagstuk. Zoals eerder in deze arbeidsmarktverkenning is geconstateerd zijn echter de gehanteerde sectoren beroepsindelingen in dit informatiesysteem niet voldoende herkenbaar en gedesaggregeerd voor de beleidsmakers in de betreffende (sub)sectoren. De gegevens waarmee het ROA-informatiesysteem (en ook andere arbeidsmarktmodellen in de zorg- en welzijnssector) worden gevoed zijn simpelweg te grof van snit. $^{17}$

Er zijn voor het platform drie mogelijkheden om tot beter bruikbare gegevens voor het arbeidsmarktmodel voor de zorg- en welzijnssector te komen. Het platform zou daarmee naar de toekomst toe concreet gestalte kunnen geven aan het motto "van grof naar fijn, op termijn".

Aanpassen standaard beroepenclassificatie en bedrijfsindeling CBS

In de eerste plaats zou het platform het CBS kunnen bewegen de standaard beroepenclassificatie en bedrijfsindeling aan te passen, zodat deze beter herkenbaar (en bruikbaar!) zijn voor het arbeidsmarktonderzoek in de zorg- en welzijnssector. Begin jaren negentig heeft het CBS haar toen (sterk) verouderde beroepen- en bedrijfsclassificaties herzien. Echter, de voorstellen die toen en daarna zijn gedaan om de beroepenindeling conform de vijf door het NIZW onderscheiden beroependomeinen als uitgangspunt te nemen voor de sociaalagogische beroepen heeft tot op heden geen weerklank gevonden (zie ook Peters, 1994). Een verfijning van de beroepsinformatie op basis van een aangepaste CBSberoepenclassificatie lijkt derhalve niet de oplossing op korte termijn. Op het

17. Op het moment dat het schoolverlatersonderzoek ook de afgestudeerden van de academische opleidingen gaat omvatten, is het overigens wel mogelijk de gegevens uit het ROA-informatiesysteem verder te verfijnen en aan te passen aan de beroepen- en sectorindeling zoals het platform voorstaat. Ook dan betreft het arbeidsmarktmodel in de eerste plaats de nieuwkomers op de arbeidsmarkt. 
moment dat het platform en andere actoren in de zorg- en welzijnssector er in slagen om beroepeninformatie in belangrijke registraties volgens een eigen indeling te genereren, kan dit voor het CBS - in omgekeerde zin - wel een aanleiding zijn om haar eigen beroepenclassificatie hierop af te stemmen.

\section{Verzekerdenadministratie BVG}

In de tweede plaats zou de beroepen- en sectorinformatie kunnen worden verfijnd door gebruik te maken van de externe in-, door- en uitstroomgegevens uit de verplichte Verzekerdenadministratie (VA-bestand) van de BVG, in combinatie met gegevens van de Gemeenschappelijke Verwijs Index (GVI) van alle bedrijfsverenigingen gezamenlijk. ${ }^{18}$ Het VA-bestand van de BVG bestaat sinds 1988 en bevat informatie tot op persoonsniveau. Van de in dit bestand opgenomen personen zijn sinds 1988 alle dienstverbanden geregistreerd. De bij deze bedrijfsverenigingen aangesloten instellingen zijn hiervoor meldingsplichtig, hetgeen de dekkingsgraad van deze bestanden sterk verhoogd.

Daarnaast is ook het bestand van de Ziektewet Registratie (ZWR) gekoppeld aan dit VA-bestand. Gegevens over het verzuim als gevolg van ziekte of bevallingsverlof, die een indicator kunnen vormen voor de kwaliteit van de arbeidsomstandigheden in de zorg- en welzijnssector, kunnen dan ook direct in dit stroommodel worden opgenomen (zie ook resultaten verzuimgegevens in paragraaf 3.2.8).

Juist doordat de BVG niet alleen de bedrijfsvereniging is voor de intramurale en extramurale zorgsector, maar tevens de maatschappelijke dienstverlening en de sociaal-culturele instellingen onder haar hoede heeft, zijn de gegevens uit het VAbestand ook goed bruikbaar voor het op gedetailleerd niveau in kaart brengen van de arbeidsmarktontwikkelingen in de sociaal-agogische beroependomeinen van de zorg- en welzijnssector. Voor het verfijnen van de arbeidsmarktinformatie uit het informatiesysteem onderwijs-arbeidsmarkt van het ROA lijkt het derhalve zinvol om de gegevens van de verzekerdenadministratie van de BVG te benutten. Temeer daar dan ook consistente vergelijkingen mogelijk zijn tussen de resultaten in de intramurale en extramurale zorgsector en de welzijnssector (zie ook Van der Windt, 1995).

18. Het GVI bevat echter geen informatie over personen die werkzaam zijn, maar niet bij een bedrijfsvereniging zijn aangesloten. Het gaat hier bijvoorbeeld om ambtenaren met een vast contract, alsmede de zelfstandigen. Voor de gegevens over de ontbrekende sectoren kan eventueel gebruik worden gemaakt van gegevens uit de EBB. 
In bijlage 5 is een overzicht opgenomen van de voor de zorg- en welzijnssector relevante beroepscategorieën, onderverdeeld naar beroependomein, zoals deze door de BVG worden onderscheiden. Sinds 1993 maakt de BVG gebruik van een gedetailleerdere beroepenindeling. De beroepeninformatie die vóór 1993 is ingevoerd in het VA-bestand is echter niet te vertalen naar deze nieuwe beroepenclassificatie. Dit is met name lastig bij het bepalen van de door- en uitstroomgegevens na 1993 van beroepsbeoefenaren die vóór 1993 zijn ingestroomd in de zorg- en welzijnssector. Omgekeerd kan informatie die volgens de nieuwe beroepenindeling in het bestand is vermeld wel - in grote lijnen - worden teruggekoppeld naar informatie volgens de oude beroepenindeling. Echter de beroepeninformatie conform de oude indeling is met name voor de maatschappelijk en cultureel werkenden te globaal onderscheiden.

Enkele kanttekeningen zijn hierbij op zijn plaats.

Hoewel de BVG-beroepsgroepen van groepsleiders, maatschappelijk werkenden alsmede jeugdleiders en buurtwerkers de beroependomeinen van respectievelijk het sociaal-pedagogisch werk, het maatschappelijk werk en dienstverlening en het sociaal-cultureel werk in hoge mate weerspiegelen, komt de afbakening van deze BVG-beroepsgroepen niet geheel overeen met de nieuwe beroepenstructuur voor de zorg- en welzijnssector zoals deze door het NIZW is geformuleerd (zie ook bijlage 5). ${ }^{19}$ Als eerste stap in de verfijning van de beroepenformatie is de (nieuwe) beroepenindeling van de BVG echter wel bruikbaar voor het arbeidsmarktonderzoek in de zorg- en welzijnssector. Zeker wanneer deze beroepeninformatie wordt onderscheiden naar de deelsector waarin deze beroepsbeoefenaren werkzaam zijn. Voor de sectorindeling hanteert de BVG zowel de CAO-code (voor het indelen van de werknemers) als Standaard Bedrijfsindeling van het CBS (voor het indelen van de instelling/organisatie).

Hoewel de bij de BVG aangesloten instellingen een meldingsplicht hebben ten aanzien van (wijzigingen in) de arbeidsverhoudingen van werknemers, blijkt de registratie in de praktijk minder feilloos te verlopen, hetgeen de betrouwbaarheid van deze gegevens negatief beïnvloedt. De BVG onderzoekt derhalve geregeld de kwaliteit van het VA-bestand (Henzen \& Wolde, 1995). In 1995 bleek bij $30 \%$ van de in dit kwaliteitsonderzoek onderzochte werknemers het beroep niet correct te zijn gecodeerd. Het gaat hier om gevallen waarbij de beroepencode niet of onjuist is

19. Overigens dient men wel rekening te houden met het feit dat de leidinggevenden bij de BVG-indeling tot afzonderlijke categorieën worden gerekend, en niet bij het betreffende beroependomein worden ondergebracht. Zo worden managers, sectorhoofden en groepchefs, evenals stafmedewerkers en hoofdverpleegkundigen ieder afzonderlijk onderscheiden (volgens BVG-indeling 1991). 
ingevuld, of bij functiewijziging niet is aangepast. Daarnaast zijn voor de werknemers die vóór de wijziging van de beroepenindeling in 1993 in dienst zijn gekomen de oude codes in het VA-bestand niet vervangen door de nieuwe. Deze oude codes zijn ook verdisconteerd in het foutenpercentage. Het aantal arbeidsverhoudingen met de oude beroepencodes neemt af, hetgeen te zien is aan de (sterke) daling van het foutenpercentage ten aanzien van de beroepencodering de afgelopen jaren (van 51\% in 1992 tot 30\% in 1995). Ondanks deze sterke afname is het percentage niet correcte beroepencoderingen nog altijd hoog. Voor een betere betrouwbaarheid (en dus bruikbaarheid) van deze gegevens voor vulling van het arbeidsmarktmodel voor de zorg- en welzijnssector is het derhalve van groot belang dat vanuit de sector goede onderlinge afspraken worden gemaakt met betrekking tot het coderen van de beroepen. Zeker waar het de afbakening tussen de verschillende beroepsgroepen betreft. In dit verband is het zinvol op te merken dat de BVG openstaat voor nadere afspraken met de zorg- en welzijnssector rondom afbakening en mogelijke verfijning van deze beroepenindeling.

Ten aanzien van de bruikbaarheid van de BVG-gegevens voor het voeden van de matrix sector, beroep èn opleiding het volgende. In het VA-bestand van de BVG zijn geen opleidingsgegevens van de werknemers opgenomen. Het is dus niet mogelijk om alleen op basis van dit BVG-bestand, op persoonsniveau, de bovengenoemde driedimensionale matrix te maken. Nadat op basis van de BVG-gegevens de beroepeninformatie - in vergelijking met de huidige EBB-gegevens - is gedesaggregeerd, zal op basis van informatie over de (hoogst) genoten opleiding van de beroepsbeoefenaren uit de $\mathrm{EBB}^{20}$ (en schoolverlatersonderzoeken) de matrix sector * beroep * opleiding verder moeten worden ingevuld. Vervolgens kan deze driedimensionale datamatrix, die voor meerdere jaren uit een (prognose)periode wordt opgesteld, worden benut voor het bepalen van de in-, door- en uitstroom in de verschillende beroepscategorieën in de zorg- en welzijnssector. Op basis van deze arbeidsmarktstromen kunnen daarna de diverse arbeidsmarktindicatoren worden berekend.

\section{Personeelsinformatiesysteem RAET}

Het platform zou voor de verfijning van de arbeidsmarktgegevens in de derde plaats ook gebruik kunnen maken van de gegevens die de zorg- en welzijnsinstellingen in hun personeelsinformatiesystemen hebben opgenomen (of hebben laten opnemen). Personeelsinformatiesystemen kunnen in potentie - op persoonsniveau - een schat

20. Tegenwoordig kunnen de gegevens uit het informatiesysteem onderwijs-arbeidsmarkt die zijn uitgesplitst naar de opleidingsachtergrond van de beroepsbeoefenaren worden onderscheiden op het laagste aggregatieniveau (SOI 5 digit). Uiteraard voor zover het aantal beroepsbeoefenaren in de betreffende categorie voldoende hoog is. 
aan (arbeidsmarkt)informatie bevatten. Het afgelopen jaar heeft de VOG met RAET contact gehad om na te gaan in hoeverre de personeelsinformatiesystemen van RAET bruikbaar zijn voor (landelijk en regionaal) arbeidsmarktonderzoek.

Hoewel RAET marktleider is op het gebied van personeelsinformatiesystemen in de zorg- en welzijnssector gebruiken niet alle zorg- en welzijnsinstellingen het systeem van RAET. De vraag is in hoeverre de mogelijke arbeidsmarktinformatie op basis van de RAET-systemen representatief kan zijn voor de gehele arbeidsmarkt in de zorg- en welzijnssector in Nederland (of in hoeverre eventueel is te corrigeren voor het niet representatief zijn van deze bestanden).

Daarnaast zijn de meeste personeelsinformatiesystemen vooralsnog (louter en alleen) ingericht als zeer uitgebreide loonadministratiesystemen, waarbij voor arbeidsmarktonderzoek relevante gegevens niet als verplicht in te vullen onderdeel in het pakket zijn opgenomen. In het RAET-systeem zijn velden toegevoegd ten behoeve van het coderen van het beroep e.d., doch instellingen kunnen zelf beslissen óf zij van deze velden gebruik maken en welke indelingen zij hierbij hanteren. De door RAET bijgeleverde (doch niet verplichte) beroepen- en sectorindelingen zijn grotendeels ontleend aan de (oude) CBS-indelingen en aan de beroepenindeling die door het NZI voor de Enquête Personeelssterkte wordt gehanteerd. In het RAET-systeem is wel een veld opgenomen voor het (vrijwillig) coderen van de opleiding van de werknemer. Los van het feit dat niet alle instellingen de opleiding noteren of verkeerd coderen, gaat het hier alleen om het opleidingsniveau. Voor de opleidingsrichting is geen veld gereserveerd.

In het kader van dit onderzoek is bij RAET ook navraag gedaan omtrent de deelname, gebruik van velden en mate van betrouwbaarheid. In tegenstelling tot de BVG waar periodiek kwaliteitscontroles van bestanden plaatsvinden, heeft RAET op dit soort zaken weinig zicht.

Gegevens uit personeelsinformatiesystemen, zoals de RAET-systemen, lijken pas bruikbaar voor arbeidsmarktonderzoek op het moment dat er door de gebruikers van zowel deze systemen als degenen die hier arbeidsmarktonderzoek op willen baseren goede afspraken zijn gemaakt omtrent het gebruik en beheer van deze systemen en daaraan te koppelen sector, beroepen- en opleidingsindelingen. Ook de periodieke vulling van een landelijk datablok op basis van de personeelsgegevens van individuele instellingen zal afdoende geregeld dienen te worden, waarbij de richtlijnen uit de Wet op de Personeelsregistraties (WPR) goed in het oog gehouden dienen te worden. Daarnaast is van belang dat een voldoende en representatief aantal zorg- en welzijnsinstellingen bij een dergelijk initiatief is aangesloten. Bovendien gaat het hier niet om eenmalige afspraken, maar om een 
systematiek die continue in de praktijk moet worden gebracht, alsmede gecontroleerd. Dit vergt een lange adem.

\section{Human accounting voor individuele zorg- en welzijnsinstellingen}

Bij de hierboven geschetste mogelijkheden voor het opzetten en uitvoeren van een periodieke verkenning op basis van een stroommodel voor de arbeidsmarkt in de zorg- en welzijnssector is de nadruk gelegd op een landelijk aangestuurde gegevensverzameling en produktontwikkeling. Echter in een tijd dat het kwalificatiebeleid en de daaraan gekoppelde kwaliteitszorg in alle instellingen gemeengoed moet gaan worden, ligt het voor de hand om de individuele instellingen in de zorg- en welzijnssector sterker bij een dergelijke arbeidsmarktverkenning te betrekken. Niet alleen bij het 'voeden' van de gegevensbronnen voor een arbeidsmarktverkenning, zoals direct bij het gebruik van personeelsinformatiesystemen of indirect bij het benutten van het BVG-bestand het geval is, maar ook door hen 'spiegelinformatie' te geven over regionale en landelijke ontwikkelingen die zij kunnen vergelijken met vergelijkbare gegevens (uit het eigen personeelsinformatiesysteem) van de instelling zelf.

Zoals ook in de aanbevelingen bij het pilot-onderzoek onder de werkgevers in de noordelijke provincies is aangegeven, zou de werkgevers voor een dergelijk onderzoek wellicht ook een software-produkt, c.q. module op het personeelsinformatiesysteem kunnen worden aangeboden, waarmee zij het eigen personeels- en scholingsbeleid goed in de gaten kunnen houden. Een soort 'human accounting'. Eens per jaar zouden deze werkgevers via een tevoren geprogrammeerde module dan enkele gegevens hieruit beschikbaar kunnen stellen.

Op basis van deze beschikbaar gestelde informatie kan dan landelijke (deel)sectorinformatie worden samengesteld. Deze landelijke informatie kan dan weer als een soort 'spiegelinformatie' terug worden gekoppeld aan de werkgevers, waardoor zij het eigen personeelsbeleid goed kunnen evalueren. Een zelfde soort systematiek hanteert het ROA bijvoorbeeld ook bij de schoolverlatersonderzoeken: onderwijsinstellingen die de oud-studenten laten enquêteren ontvangen een vertrouwelijke instellingsrapportage waarin op opleidingsniveau de resultaten voor de eigen instelling kunnen worden vergeleken met de landelijke resultaten. De onderwijsinstellingen gebruiken deze informatie met name voor het kwaliteitszorgbeleid en de voorlichting aan (aankomende) studenten. Deze aanpak heeft het draagvlak om deel te nemen aan deze onderzoeken aanmerkelijk vergroot.

Inmiddels is ook een dergelijk instrument op initiatief van de WoonZorg Federatie (WZF) ontwikkeld: de EBIS-Gegevensset (EBIS staat voor Extern 
BesturingsInformatieSysteem). Ook voor de Thuiszorg (voorheen Kruiswerk en Gezinsverzorging) is een Databank opgezet om zowel kengetallen voor de totale branche als voor de Thuiszorginstellingen te genereren. 


\section{Bijlage 1 Relevante gegevensbronnen en literatuur}

Beekmans, L., Proefrapportage Arbeidsmarkt Zorgsector, Research voor Beleid, Leiden, 1994. Borghans, L., A Histo-Topographic Map of the Dutch University Studies, ROA-W-1992/5E, Maastricht, 1992.

Borghans, L., A. de Grip, J. Hoevenberg, De bruikbaarheid van deelmarktinformatie voor het informatiesysteem onderwijs-arbeidsmarkt, ROA-R-1994/13, Maastricht, 1994.

Centraal Bureau voor de Statistiek, Standaard beroepenclassificatie 1992, (CBS) Voorburg/Heerlen, 1993

Centraal Bureau voor de Statistiek, Beroepenclassificatie 1984, (CBS) Voorburg/Heerlen, 1984.

Centraal Bureau voor de Statistiek, Standaard bedriffsindeling 1993, (CBS), Voorburg/Heerlen, 1993.

Centraal Bureau voor de Statistiek, Standaard bedriffsindeling 1978, (CBS), Voorburg/Heerlen, 1982.

Centraal Bureau voor de Statistiek, Standaard onderwijsindeling 1978, (CBS), Voorburg/Heerlen, 1983.

Commissie Ontwikkeling Kwalificatiestelsel Zorg \& Welzijn, Kwalificatiebeleid in de sector Zorg \& Welzijn. Naar een Platform van actoren, NIZW, Utrecht.

Commissie Welzijns Informatievoorziening, Eerste Kern - GFO - Welzijn, Rijswijk, 1994.

Ewijk, J.P van, C.C.M. Kester, J.T.H. Rutten, P.A.M. van den Bogaardt, Kwaliteitszorg en certificatie in de sector zorg en welzijn. Methodes om kwaliteit van de beroepsuitoefening te garanderen, Platform Kwalificatiebeleid Zorg en Welzijn, Utrecht, 1995.

Grip, A. de, E.J.T.A. Willems, J. Hoevenberg, P.J.E. van de Loo, A.G.M. Matheeuwsen, Toekomstverkenning arbeidsmarkt zorgsector, ROA-R-1994/6 Maastricht, 1994.

Heikoop, L., Kerngegevens arbeidsmarkt en werkgelegenheid welzijn, 1996.

Hens, H.A.M., M.A.A.G. Geomini, Beroepenstructuur zorg en welzijn, om de kwaliteit van het beroep, NIZW, Utrecht 1994.

Hens, H.A.M., Proeve van een beroepenstructuur voor zorg en welzijn, NIZW, Utrecht, 1992.

Hens, H.A.M., Maatschappelijke dienstverlening, Beroependomeinprofiel Stuurgroep Beroepenstructuur AbvaKabo, CFO, VOG, NIZW, Utrecht, 1995.

Hens, H.A.M., Sociaal-Pedagogisch Werk, Beroependomeinprofiel, Stuurgroep Beroepenstructuur AbvaKabo, CFO, VOG, NIZW, Utrecht, 1995.

Hens, H.A.M., Sociaal-Cultureel Werk, Beroependomeinprofiel, Stuurgroep Beroepenstructuur AbvaKabo, CFO, VOG, NIZW, Utrecht, 1995.

Henzen, M., J. van Wolde, De kwaliteit van de Verzekerdenadministratie in 1995, Een onderzoek naar de betrouwbaarheid van een aantal persoons-, verzekerings- en arbeidsverhoudingsgegevens, BVG, Zeist, 1995.

Hover, C., Het kwalificatiespel in de sector Zorg en Welzijn. Een wegwijzer voor betrokkenen. Platform Kwalificatiebeleid Zorg en Welzijn, Utrecht, 1995.

Landelijk dienstverlenend Centrum, (LDC), Waar komen onze schoolverlaters terecht? De uitstroom en bestemming van het schooljaar 1992/1993, Leeuwarden, 1995.

Loo, P.J.E. van de, R.K.W. van der Velden, De arbeidsmarkt in de zorg-en welzijnssector. Pilot-onderzoek onder werkgevers in Noord-Nederland, ROA-R-1993/2 Maastricht, 1993.

Loo, P.J.E. van de, J. Hoevenberg, R.K.W. van der Velden, de arbeidsmarktpositie van afgestudeerden van het hoger beroepsondenwijs, HBO-Monitor 1994, landelijk rapport, Voorlichtingsdienst HBO-Raad, Den Haag, 1995. 
Martens, M., P. Wiebes, I. Wisselink, Zorg en Welzijn gekarakteriseerd, voorzieningen in de sector zorg en welzijn nader omschreven, NIZW, Utrecht, 1994.

Ministerie van Sociale Zaken en Werkgelegenheid, Organisatiewet Sociale Verzekering, uitvoeringsbesluit artikel 3, beschikking Staatssecretaris Sociale Zaken 8 december 1952, Kluwer Sociale Verzekeringswetten, Deventer, 1994.

Pagrach, K.J., Loo, P.J.E. van de, J.M.J.A. Pisters, de arbeidsmarktpositie van afgestudeerden van het hoger beroepsonderwijs, HBO-Monitor 1994, statistisch supplement, Voorlichtingsdienst HBO-Raad, Den Haag, 1995.

Peters, F., Beroepenstructuur en de Standaard Beroepenclassificatie 1992, CBO-Notitie nr. 1 , NIZW, Utrecht, 1994.

Researchcentrum voor Onderwijs en Arbeidsmarkt, De arbeidsmarkt naar opleiding en beroep tot 2000, rapport, ROA-R-1995/3, Maastricht, 1995.

Researchcentrum voor Onderwijs en Arbeidsmarkt, De arbeidsmarkt naar opleiding en beroep tot 2000, statistische bijlage, ROA-R-1995/3B, Maastricht, 1995.

Researchcentrum voor Onderwijs en Arbeidsmarkt, Methodiek van het informatiesysteem onderwijs-arbeidsmarkt, werkdocument, ROA-W-1995/3, Maastricht, 1995.

Vermeulen, H.J.J.M., A. de Grip, A.M.C. Vissers, E.J.T.A. Willems, R.J.W. Pannebakker, A.G.M. Matheeuwsen, Arbeidsmarktmodel Zorgsector (AMOZ), OSA-publikatie, nr. Z6, 1995.

Windt, W. van der, Haalbaarheidsonderzoek naar de mogelijkheden van het gebruik van simulatiemodellen voor de arbeidsmarkt in de zorgsector, NZi, 1995.

Windt, W. van der, Arbeidsmarktverkenning zorg voor verstandelijk gehandicapten, NZi, 1993. 


\section{Bijlage 2 Overzicht kerncijfers per beroepsklasse en opleidingsrichting}

Tabel B2.1

Kerncijfers arbeidsmarktontwikkelingen beroepsbevolking, per ROA-beroepsklasse

\begin{tabular}{|c|c|c|}
\hline Kengetallen & $\begin{array}{l}\text { Beroepst } \\
\text { totaal beroep }\end{array}$ & $\begin{array}{l}\text { g naar beroep } \\
\text { maatschappelijk en } \\
\text { cultureel werkers }\end{array}$ \\
\hline \multicolumn{3}{|l|}{$\begin{array}{l}\text { Omvang en samenstelling } \\
\text { beroepsbevolking }\end{array}$} \\
\hline aantal werkenden (x1000) & $5.885,5$ & $\begin{array}{l}68 \\
\text { (stijgend) }\end{array}$ \\
\hline $\begin{array}{l}\text { percentage vrouwen } \\
\text { percentage deeltijdarbeid } \\
\text { percentage leeftijd }<30 \text { jaar } \\
\text { percentage hoger geschoolden }\end{array}$ & $\begin{array}{l}37 \% \\
25 \% \\
30 \% \\
24 \%\end{array}$ & $\begin{array}{l}67 \% \\
57 \% \\
16 \% \\
66 \%\end{array}$ \\
\hline \multicolumn{3}{|l|}{ Knelpunten arbeidsmarkt } \\
\hline conjunctuurgevoeligheid & - & $\begin{array}{l}0,36 \\
\text { (laag) }\end{array}$ \\
\hline $\begin{array}{l}\text { uitwijkmogelijkheden } \\
\text { naar bedrijfsklassen }\end{array}$ & $\begin{array}{l}0,69 \\
\text { (gemiddeld) }\end{array}$ & $\begin{array}{l}0,72 \\
\text { (gemiddeld) }\end{array}$ \\
\hline \multicolumn{3}{|l|}{ Werkgelegenheidsontwikkeling } \\
\hline percentage werkgelegenheidsontw. & $\begin{array}{l}4 \% \\
\text { (gemiddeld) }\end{array}$ & $\begin{array}{l}6 \% \\
\text { (gemiddeld) }\end{array}$ \\
\hline \multicolumn{3}{|l|}{ Vervangingsvraag } \\
\hline percentage vervangingsvraag & $\begin{array}{l}20 \% \\
\text { (gemiddeld) }\end{array}$ & $\begin{array}{l}26 \% \\
\text { (hoog) }\end{array}$ \\
\hline \multicolumn{3}{|l|}{ Baanopeningen } \\
\hline percentage baanopeningen & $\begin{array}{l}24 \% \\
\text { (gemiddeld) }\end{array}$ & $\begin{array}{l}32 \% \\
\text { (hoog) }\end{array}$ \\
\hline
\end{tabular}

Bron: $\mathrm{CBS} / \mathrm{CPB} / \mathrm{ROA}$ 
Tabel B2.2

Kerncijfers arbeidsmarktontwikkelingen beroepsbevolking, per ROA-opleidingstype

\begin{tabular}{|c|c|c|c|c|c|}
\hline \multirow{2}{*}{$\begin{array}{l}\text { Kengetallen } \\
\begin{array}{l}\text { Omvang en samenstelling } \\
\text { beroepsbevolking }\end{array}\end{array}$} & \multirow[t]{2}{*}{$\begin{array}{l}\text { mbo } \\
\text { totaal }\end{array}$} & \multicolumn{3}{|c|}{$\begin{array}{l}\text { Beroepsbevolking naar opleiding } \\
\text { mbo ho mbo hbo } \\
\text { soc. cult. verzorgend totaal }\end{array}$} & \multirow[t]{2}{*}{$\begin{array}{l}\text { hbo } \\
\text { soc. cult }\end{array}$} \\
\hline & & & & & \\
\hline aantal werkenden $(\times 1000)$ & 2.285 & $\begin{array}{r}52,5 \\
\text { (stijgend) } \\
68 \%\end{array}$ & $\begin{array}{r}212,5 \\
\text { (constant) } \\
81 \%\end{array}$ & $\begin{array}{r}1.022 \\
42 \%\end{array}$ & $\begin{array}{r}118 \\
\text { (constant) } \\
58 \%\end{array}$ \\
\hline \multicolumn{6}{|l|}{ Knelpunten arbeidsmarkt } \\
\hline $\begin{array}{l}\text { uitwijkmogelijkheden naar } \\
\text { bedrijfsklassen } \\
\text { uitwijkmogelijkheden naar } \\
\text { beroepsklassen }\end{array}$ & $\begin{array}{r}0,79 \\
(\mathrm{gem} .) \\
0,83 \\
(\mathrm{gem} .)\end{array}$ & $\begin{array}{r}0,51 \\
\text { (laag) } \\
0,87 \\
\text { (hoog) } \\
0,89 \\
\text { (hoog) }\end{array}$ & $\begin{array}{r}0,51 \\
\text { (laag) } \\
0,87 \\
\text { (hoog) } \\
0,88 \\
\text { (gem.) }\end{array}$ & $\begin{array}{r}0,81 \\
(\text { hoog) } \\
0,93 \\
(\text { hoog) }\end{array}$ & $\begin{array}{r}0,49 \\
\text { (laag) } \\
0,88 \\
(\text { hoog) } \\
0,85 \\
(\text { gem.) }\end{array}$ \\
\hline \multicolumn{6}{|l|}{ Werkgelegenheidsontwikkeling } \\
\hline $\begin{array}{l}\text { percentage } \\
\text { werkgelegenheidsontw. }\end{array}$ & $\begin{array}{r}5 \% \\
(\mathrm{gem} .)\end{array}$ & $\begin{array}{r}2 \% \\
\text { (laag) }\end{array}$ & $\begin{array}{r}4 \% \\
(\text { gem.) }\end{array}$ & $\begin{array}{r}14 \% \\
\text { (hoog) }\end{array}$ & $\begin{array}{r}12 \% \\
\text { (gem.) }\end{array}$ \\
\hline \multicolumn{6}{|l|}{ Vervangingsvraag } \\
\hline percentage vervangingsvraag & $\begin{array}{r}16 \% \\
\text { (hoog) }\end{array}$ & $\begin{array}{r}12 \% \\
\text { (gem.) }\end{array}$ & $\begin{array}{r}14 \% \\
\text { (gem.) }\end{array}$ & $\begin{array}{r}16 \% \\
\text { (hoog) }\end{array}$ & $\begin{array}{r}16 \% \\
\text { (hoog) }\end{array}$ \\
\hline \multicolumn{6}{|l|}{ Baanopeningen } \\
\hline percentage baanopeningen & $\begin{array}{r}21 \% \\
\text { (gem.) }\end{array}$ & $\begin{array}{r}13 \% \\
\text { (erg laag) }\end{array}$ & $\begin{array}{r}18 \% \\
\text { (laag) }\end{array}$ & $\begin{array}{r}30 \% \\
\text { (hoog) }\end{array}$ & $\begin{array}{r}28 \% \\
\text { (hoog) }\end{array}$ \\
\hline \multicolumn{6}{|l|}{ Instroom schoolverlaters } \\
\hline $\begin{array}{l}\text { percentage instroom } \\
\text { schoolverlaters }\end{array}$ & $\begin{array}{r}22 \% \\
\text { (gem.) }\end{array}$ & $\begin{array}{r}34 \% \\
\text { (hoog) }\end{array}$ & $\begin{array}{r}29 \% \\
\text { (hoog) }\end{array}$ & $\begin{array}{r}20 \% \\
\text { (gem.) }\end{array}$ & $\begin{array}{r}27 \% \\
\text { (gem.) }\end{array}$ \\
\hline \multicolumn{6}{|l|}{ Toekomstig perspectief } \\
\hline relatief arbeidsmarktperspectief & - & $\begin{array}{r}1,20 \\
\text { (slecht) }\end{array}$ & $\begin{array}{r}1,14 \\
\text { (matig) }\end{array}$ & - & $\begin{array}{r}0,99 \\
\text { (goed) }\end{array}$ \\
\hline
\end{tabular}

Bron: CBS/CPB/ROA 
Tabe/ B2.3

Kerncijfers arbeidsmarktontwikkelingen schoolverlaters, per opleidingsrichting

\begin{tabular}{|c|c|c|c|c|c|c|c|c|c|}
\hline & $\begin{array}{l}\text { hbo } \\
\text { soc. } \\
\text { pedag. }\end{array}$ & hsao & $\begin{array}{l}\text { Schoc } \\
\text { hbo } \\
\text { totaal }\end{array}$ & $\begin{array}{l}\text { olverlater } \\
\text { mbo } \\
\text { soc. } \\
\text { arbeid }\end{array}$ & $\begin{array}{l}\text { ers naar } \\
\text { mbo } \\
\text { activ. } \\
\text { begel. }\end{array}$ & $\begin{array}{l}\text { opleidin } \\
\text { mbo } \\
\text { verz. }\end{array}$ & $\begin{array}{l}\text { ngsrichtin } \\
\text { mbo } \\
\text { agog. }\end{array}$ & mang & $\begin{array}{l}\text { mbo } \\
\text { totaal }\end{array}$ \\
\hline \multicolumn{10}{|l|}{$\begin{array}{l}\text { Samenstelling } \\
\text { populatie }\end{array}$} \\
\hline percentage vrouwen & $84 \%$ & $78 \%$ & $53 \%$ & $83 \%$ & $96 \%$ & $99 \%$ & $92 \%$ & $92 \%$ & $55 \%$ \\
\hline \multicolumn{10}{|l|}{$\begin{array}{l}\text { Knelpunten } \\
\text { arbeidsmarkt }\end{array}$} \\
\hline $\begin{array}{l}\text { percentage > } 3 \text { mnd. } \\
\text { werkzoekend }\end{array}$ & $12 \%$ & $16 \%$ & $18 \%$ & $21 \%$ & $14 \%$ & $11 \%$ & $21 \%$ & $15 \%$ & $14 \%$ \\
\hline $\begin{array}{l}\text { percentage werkloos } \\
\text { enquetemoment }\end{array}$ & $5 \%$ & $6 \%$ & $8 \%$ & $19 \%$ & $7 \%$ & $5 \%$ & $8 \%$ & $7 \%$ & $7 \%$ \\
\hline $\begin{array}{l}\text { percentage werk } \\
\text { in deeltijd }\end{array}$ & $60 \%$ & $52 \%$ & $30 \%$ & $39 \%$ & $67 \%$ & $40 \%$ & $55 \%$ & $45 \%$ & $28 \%$ \\
\hline $\begin{array}{l}\text { percentage met } \\
\text { vaste aanstelling }\end{array}$ & $81 \%$ & $72 \%$ & $63 \%$ & $39 \%$ & $71 \%$ & $72 \%$ & $71 \%$ & $71 \%$ & $66 \%$ \\
\hline $\begin{array}{l}\text { bruto maandsalaris } \\
\text { (in guldens) }\end{array}$ & 2960 & 3330 & 3250 & 1910 & 1830 & 1810 & 1610 & 1740 & 1920 \\
\hline $\begin{array}{l}\text { bruto uurloon } \\
\text { (in guldens) }\end{array}$ & 20,70 & 23,00 & 21,00 & 13,20 & 15,40 & 12,40 & 12,20 & 12,50 & 12,60 \\
\hline
\end{tabular}





\section{Bijlage 3 Samenstelling beroepsbevolking naar beroepsklassen, bedrijfsklassen en opleidingstypen $^{21}$}

Tabel B3.1

Omvang beroepsbevolking naar beroepsklassen per bedrijfsklasse (in procenten)

Zwakzwakzinnigeninrichtingen (excl.gezinsvervangende tehuizen)

Verpleegkundigen

Leerling-verpleegkundigen, zieken-, zwakzinnigen- en kraamverzorgenden

Maatschappelijk en cultureel werkers

Kinder-, gezins- en bejaardenverzorgenden

Overig

Verpleeghuizen

Verpleegkundigen

Leerling-verpleegkundigen, zieken-, zwakzinnigen- en kraamverzorgenden

Maatschappelijk en cultureel werkers

Kinder-, gezins- en bejaardenverzorgenden

Overig

Bejaardentehuizen e.d.

Verpleegkundigen

Leerling-verpleegkundigen, zieken-, zwakzinnigen- en kraamverzorgenden

Maatschappelijk en cultureel werkers

Kinder-, gezins- en bejaardenverzorgenden

Overig

Kinderteh.,soc.tehuizen e.d. voor niet-gehandicapten

Verpleegkundigen

Leerling-verpleegkundigen, zieken-, zwakzinnigen- en kraamverzorgenden

Maatschappelijk en cultureel werkers

Kinder-, gezins- en bejaardenverzorgenden

Overig

Tehuizen en dagverbl. gehandicapt. (geen medische behandeling)

Verpleegkundigen

Leerling-verpleegkundigen, zieken-, zwakzinnigen- en kraamverzorgenden

Maatschappelijk en cultureel werkers

Kinder-, gezins- en bejaardenverzorgenden

Overig

21. Legenda:

- : te weinig waarnemingen voor presentatie van het getal $(<=2.500$ waarnemingen);

$x$ : geen waarnemingen in betreffende categorie;

$0:$ wel waarnemingen in betreffende categorie, echter afgerond 0 procent. 
Tabel B3.1 (vervolg)

Omvang beroepsbevolking naar beroepsklassen per bedrijfsklasse (in procenten)

Beroepsklassen per bedrijfsklasse

Percentage

Soc.-medische, -psychologische en pedagogische diensten e.d.

Verpleegkundigen

Leerling-verpleegkundigen, zieken-, zwakzinnigen- en kraamverzorgenden

Maatschappelijk en cultureel werkers

Kinder-, gezins- en bejaardenverzorgenden

Overig

Maatschappelijke organisaties

Verpleegkundigen

Leerling-verpleegkundigen, zieken-, zwakzinnigen- en kraamverzorgenden

Maatschappelijk en cultureel werkers

Kinder-, gezins- en bejaardenverzorgenden

Overig

Gezinsverzorging en gezinshulp e.d.

Verpleegkundigen

Leerling-verpleegkundigen, zieken-, zwakzinnigen- en kraamverzorgenden

Maatschappelijk en cultureel werkers

Kinder-, gezins- en bejaardenverzorgenden

Overig

Kinderdagverblijven, creches (gezonde kinderen)

Verpleegkundigen

Leerling-verpleegkundigen, zieken-, zwakzinnigen- en kraamverzorgenden

Maatschappelijk en cultureel werkers

Kinder-, gezins- en bejaardenverzorgenden

Overig

Buurt- en clubhuiswerk en samenlevingsopbouwwerk

Verpleegkundigen

Leerling-verpleegkundigen, zieken-, zwakzinnigen- en kraamverzorgenden

Maatschappelijk en cultureel werkers

Kinder-, gezins- en bejaardenverzorgenden

Overig

Jeugd- en jongerenwerk

Verpleegkundigen

Leerling-verpleegkundigen, zieken-, zwakzinnigen- en kraamverzorgenden

Maatschappelijk en cultureel werkers

Kinder-, gezins- en bejaardenverzorgenden

Overig 
Tabel B3.1 (vervolg)

Omvang beroepsbevolking naar beroepsklassen per bedrijfsklasse (in procenten)

Beroepsklassen per bedrijfsklasse

Vormingswerk (buiten schoolverband)

Verpleegkundigen

Leerling-verpleegkundigen, zieken-, zwakzinnigen- en kraamverzorgenden

Maatschappelijk en cultureel werkers

Kinder-, gezins- en bejaardenverzorgenden

Overig

Totaal bedrijven

Verpleegkundigen

Leerling-verpleegkundigen, zieken-, zwakzinnigen- en kraamverzorgenden

Maatschappelijk en cultureel werkers

Kinder-, gezins- en bejaardenverzorgenden

Overig 
Tabel B3.2

Omvang beroepsbevolking naar bedrijfsklassen per beroepsklasse (in procenten)

Verpleegkundigen

Zwakzinnigeninrichtingen (excl. gezinsverv, tehuizen)

Verpleeghuizen

Bejaardentehuizen e.d.

Kinderteh.,soc.tehuizen e.d. voor niet-gehandicapten

Tehuizen en dagverbl. gehandicapt. (geen med. behand.)

Soc.-medische, -psychol. en pedagog. diensten e.d.

Maatschappelijke organisaties

Gezinsverzorging en gezinshulp e.d.

Kinderdagverblijven, creches (gezonde kinderen)

Buurt- en clubhuiswerk en samenlevingsopbouwwerk

Jeugd- en jongerenwerk

Vormingswerk (buiten schoolverband)

Overig

Leerling-verpleegkundigen, zieken-, zwakzinnigen- en kraamverzorgenden

Zwakzinnigeninrichtingen (excl. gezinsverv. tehuizen)

Verpleeghuizen

Bejaardentehuizen e.d.

Kinderteh.,soc.tehuizen e.d. voor niet-gehandicapten

Tehuizen en dagverbl. gehandicapt. (geen med. behand.)

Soc.-medische, -psychol. en pedagog. diensten e.d.

Maatschappelijke organisaties

Gezinsverzorging en gezinshulp e.d.

Kinderdagverblijven, creches (gezonde kinderen)

Buurt- en clubhuiswerk en samenlevingsopbouwwerk

Jeugd- en jongerenwerk

Vormingswerk (buiten schoolverband)

Overig

Maatschappelijk en cultureel werkers

Zwakzinnigeninrichtingen (excl. gezinsverv. tehuizen) 3

Verpleeghuizen

Bejaardentehuizen e.d.

Kinderteh., soc.tehuizen e.d. voor niet-gehandicapten

Tehuizen en dagverbl. gehandicapt. (geen med. behand.)

Soc.-medische, -psychol. en pedagog. diensten e.d.

Maatschappelijke organisaties

Gezinsverzorging en gezinshulp e.d.

Kinderdagverblijven, creches (gezonde kinderen)

Buurt- en clubhuiswerk en samenlevingsopbouwwerk

Jeugd- en jongerenwerk

Vormingswerk (buiten schoolverband) 
Tabel B3.2 (vervolg)

Omvang beroepsbevolking naar bedrijfsklassen per beroepsklasse (in procenten)

Kinder-, gezins- en bejaardenverzorgenden

Zwakzinnigeninrichtingen (excl. gezinsverv. tehuizen)

Verpleeghuizen

Bejaardentehuizen e.d.

Kinderteh.,soc.tehuizen e.d. voor niet-gehandicapten

Tehuizen en dagverbl. gehandicapt. (geen med. behand.)

Soc.-medische, -psychol. en pedagog. diensten e.d.

Maatschappelijke organisaties

Gezinsverzorging en gezinshulp e.d.

Kinderdagverblijven, creches (gezonde kinderen)

Buurt- en clubhuiswerk en samenlevingsopbouwwerk

Jeugd- en jongerenwerk

Vormingswerk (buiten schoolverband)

Overig

Totaal bedrijfsklassen

Zwakzinnigeninrichtingen (excl. gezinsverv. tehuizen) 0.6

Verpleeghuizen

Bejaardentehuizen e.d.

Kinderteh.,soc.tehuizen e.d. voor niet-gehandicapten

Tehuizen en dagverbl. gehandicapt. (geen med. behand.)

Soc.-medische, -psychol. en pedagog. diensten e.d.

Matschappelijke organisaties

Gezinsverzorging en gezinshulp e.d.

Kinderdagverblijven, creches (gezonde kinderen)

Buurt- en clubhuiswerk en samenlevingsopbouwwerk

Jeugd-en jongerenwerk

Vormingswerk (buiten schoolverband)

Bron: ROA/CBS 
Tabel B3.3

Omvang beroepsbevolking naar opleidingstypen per beroepsklasse (in procenten)

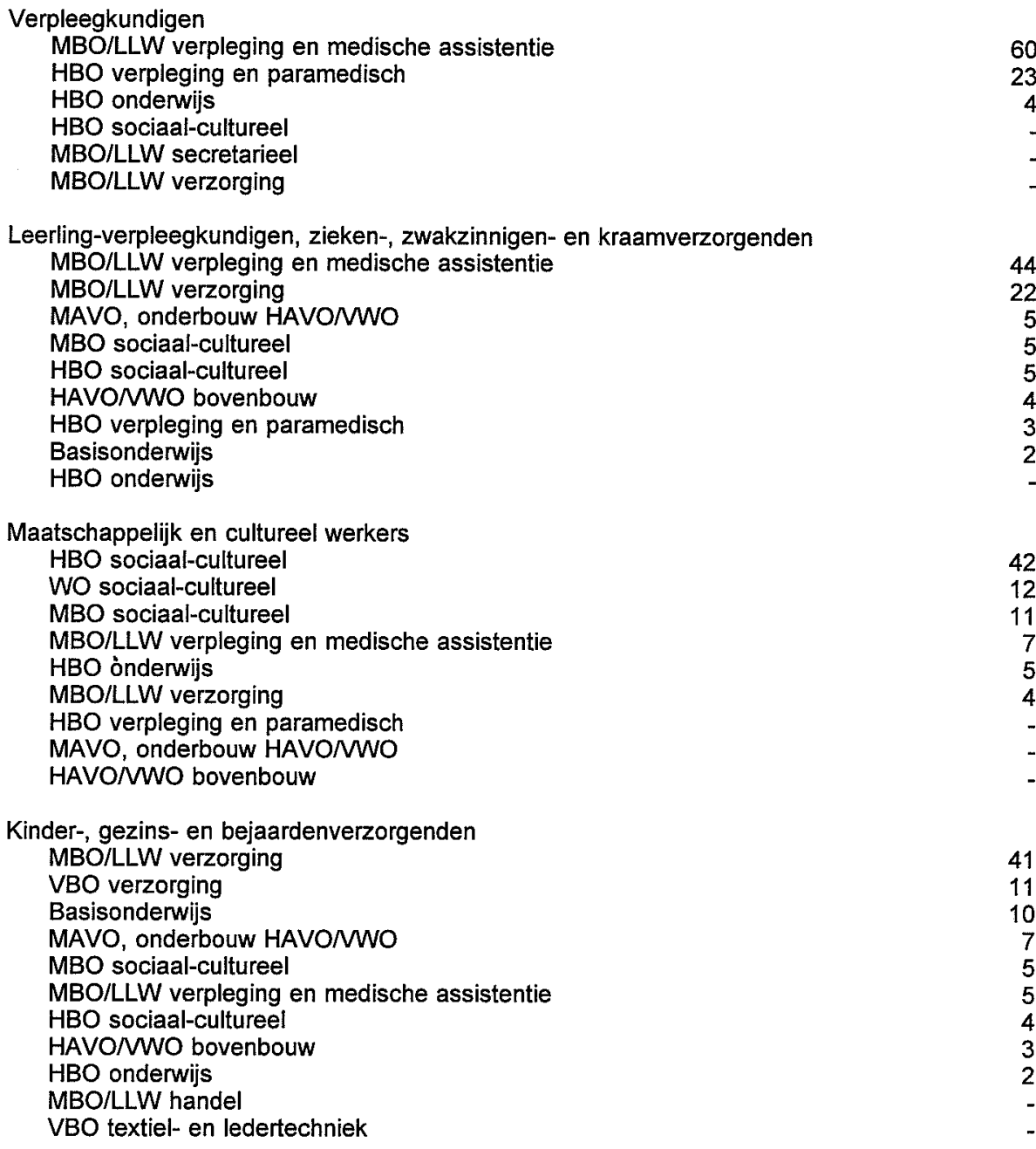

Bron: ROA/CBS 


\section{Bijlage 4 Indeling ROA-bedrijfsklassen, ROA- beroepsklassen en ROA-opleidingstypen}

Tabel B4.1

Indeling ROA-bedrijfsklassen, naar Standaard Bedrijfsindeling (SBI), 1978, CBS (3 digit)

ROA-Bedrijfsklassen

SBI-code

Zwakzinnigeninrichtingen (excl. gezinsvervangende tehuizen)

Verpleeghuizen

Bejaardentehuizen e.d.

Kindertehuizen, sociale tehuizen e.d. voor niet-gehandicapten

Tehuizen en dagverblijven voor gehandicapten (geen medische behandeling) 943

Sociaal-medische, -psychologische en pedagogogische diensten e.d.

Maatschappelijke organisaties

Gezinsverzorging en gezinshulp e.d.

Kinderdagverblijven, crèches (gezonde kinderen)

Jeugd- en jongerenwerk 952

Vormingswerk (buiten schoolverband)

Tabel B4.2

Indeling ROA-beroepsklassen, naar ROA-beroepsklassenindeling (4 digit) en CBS-beroepsgroepenindeling 1984 ( 3 digit)

\begin{tabular}{lll}
\hline Beroepsklassen & ROA-code & CBS-codes \\
\hline $\begin{array}{l}\text { Verpleegkundigen } \\
\text { Leerling-verpleegkundigen, zieken-/zwakzinnigen-/ }\end{array}$ & 5021 & 071,073 \\
kraamverzorgenden & 5022 & 072,074 \\
Maatschappelijk en cultureel werkers & 7033 & 193 \\
Kinder-, gezins- en bejaardenverzorgenden & 8212 & 542 \\
\hline
\end{tabular}

Tabel B4.3

Indeling ROA-opleidingstypen, naar Standaard Onderwijs Indeling (SOI), CBS, 1978 (5 digit)

Opleidingstypen

VBO verzorging

MBO sociaal-culturee

$\mathrm{MBO} / L L W$ verzorging

HBO onderwijs

HBO sociaal-cultureel

WO sociaal-cultureel
SOI-codes

38100-38999

48100-48199, 4840048499

48600-48699

50600-50699, 60600-60699

57100-57199

$67100-67199,70663$

Bron: ROA/CBS 



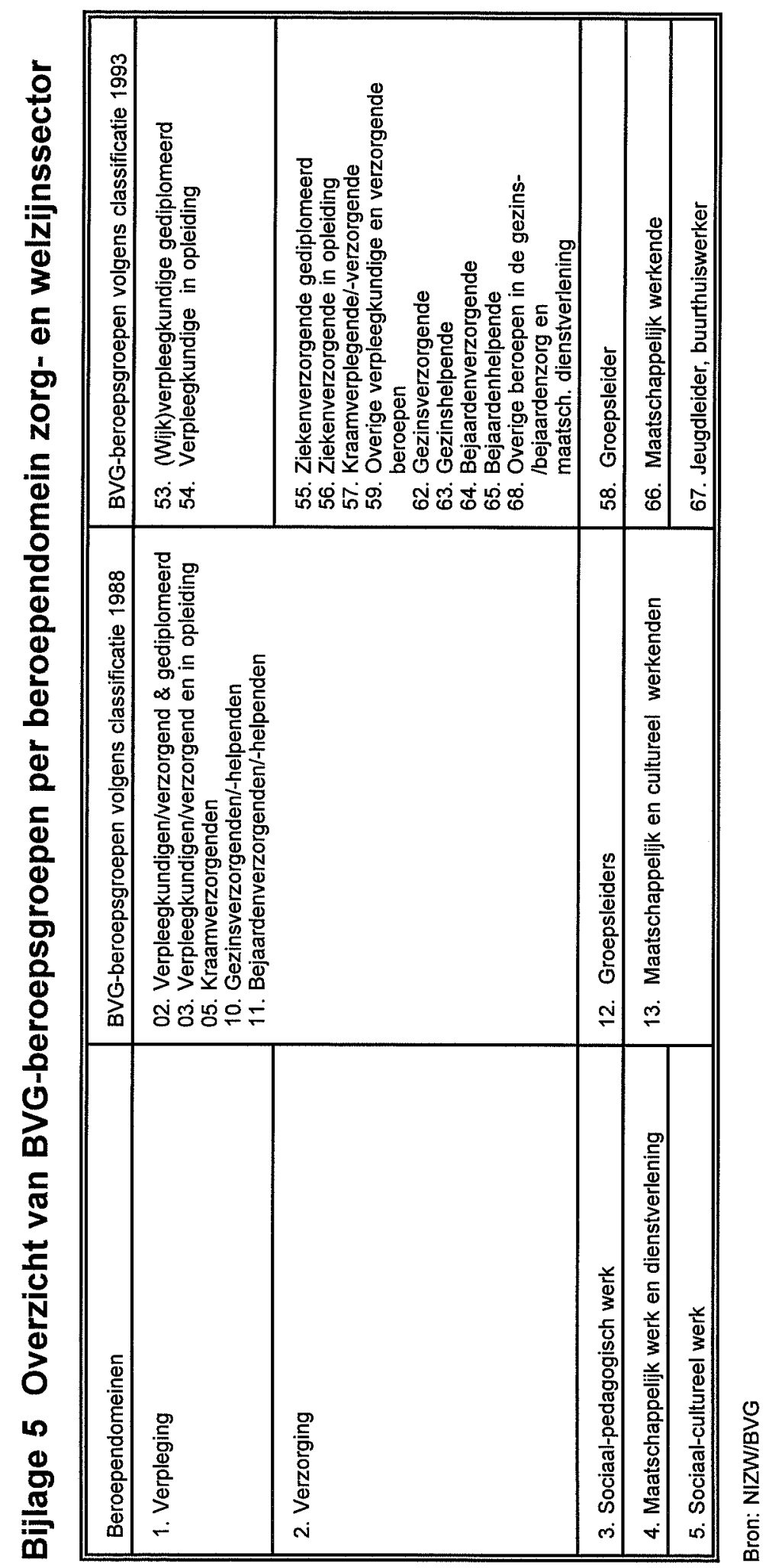





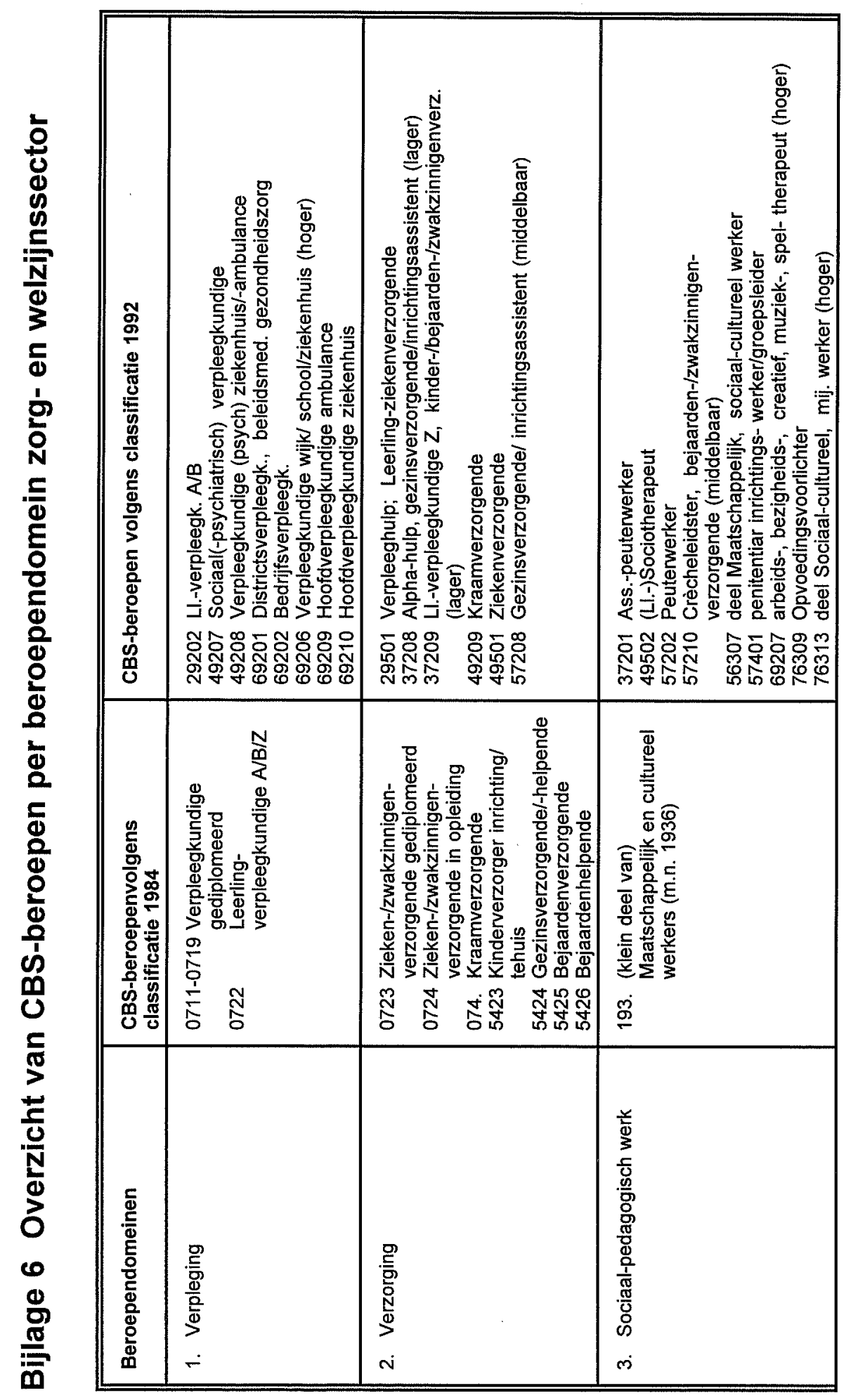




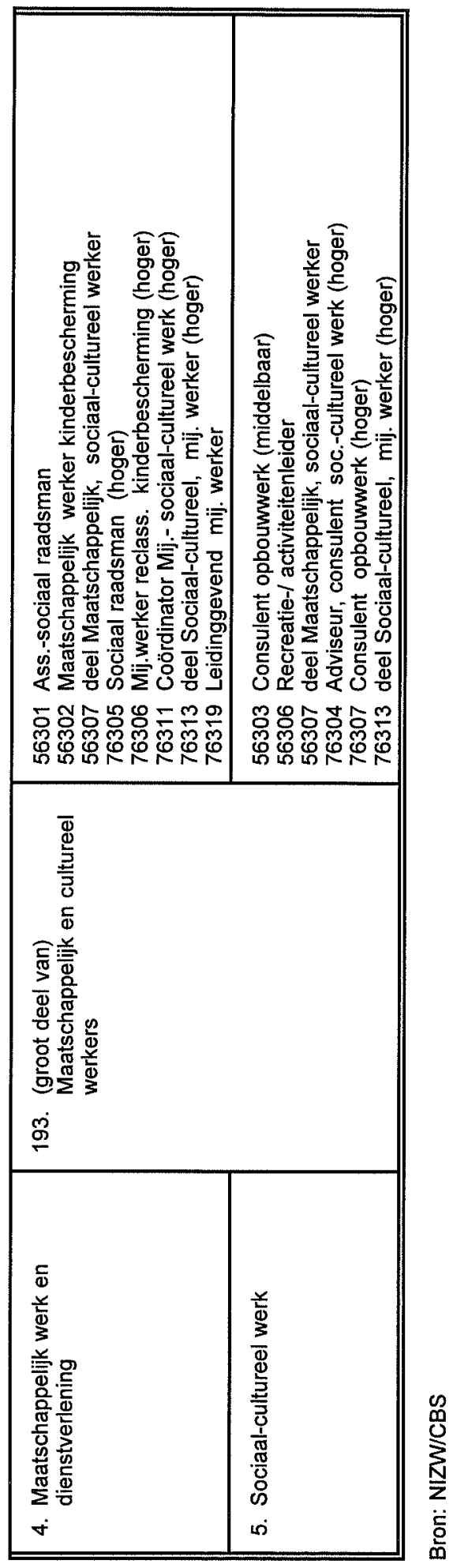

